\title{
ZUSGS
}

\section{Geology of the Prince William Sound and Kenai Peninsula Region, Alaska}

\section{Including the Kenai, Seldovia, Seward, Blying Sound, Cordova, and Middleton Island 1:250,000-scale quadrangles}

By Frederic H. Wilson and Chad P. Hults

Pamphlet to accompany

Scientific Investigations Map 3110

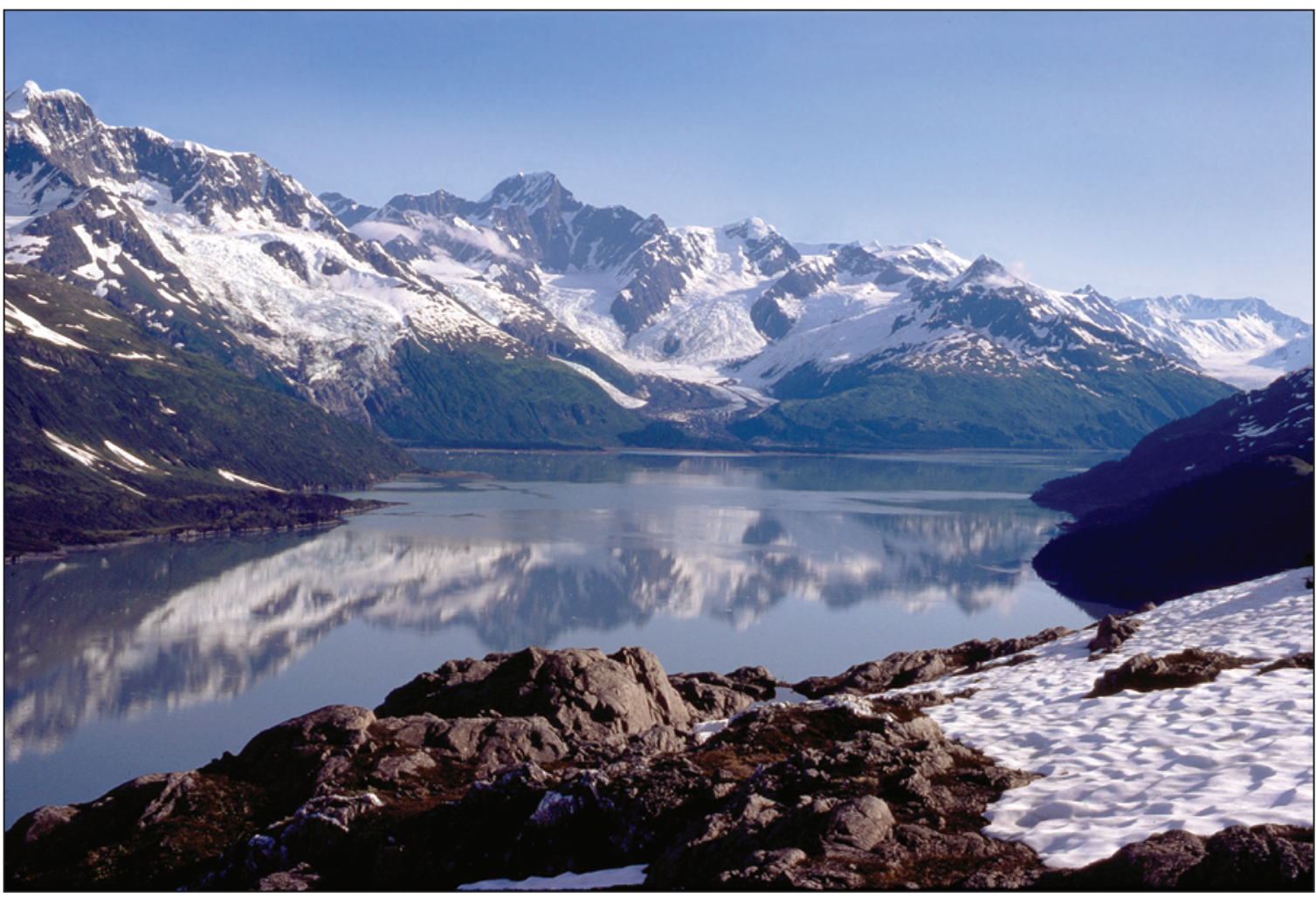

View looking east down Harriman Fiord at Serpentine Glacier and Mount Gilbert. (photograph by M.L. Miller)

U.S. Department of the Interior

U.S. Geological Survey 



\section{Contents}

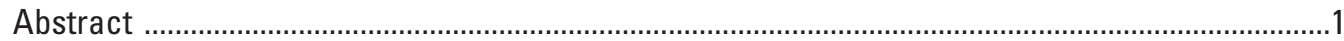

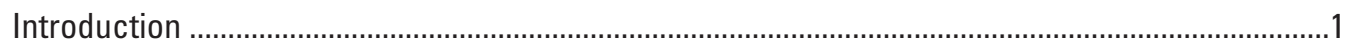

Geographic, Physiographic, and Geologic Framework ................................................................

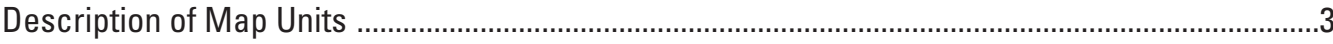

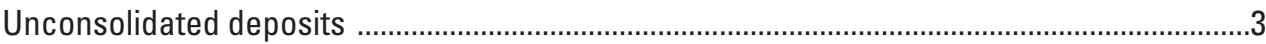

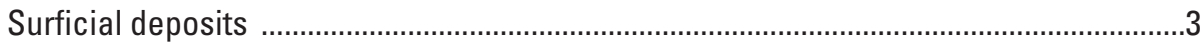

Rock Units West of the Border Ranges Fault System ...........................................................5

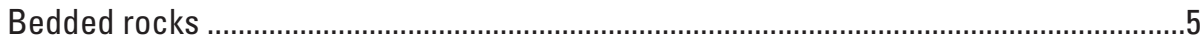

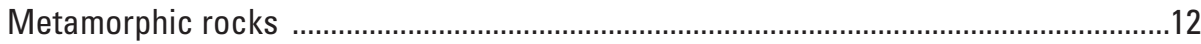

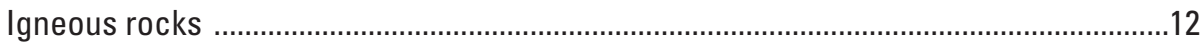

Rock Units within the Border Ranges Fault System ..........................................................14

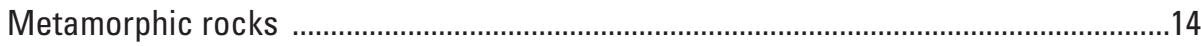

Rock Units East or South of the Border Ranges Fault System ...............................................14

Bedded rocks ..................................................................................................................

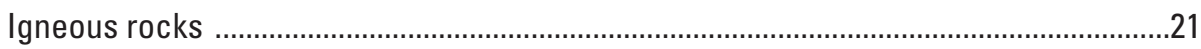

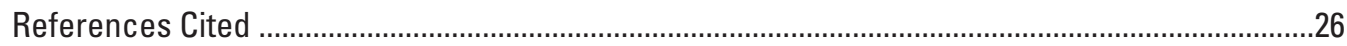

\section{Tables}

Table 1. Radiometric ages from the Prince William Sound and Cook Inlet region . .31 



\section{Abstract}

The Prince William Sound and Kenai Peninsula region includes a significant part of one of the world's largest accretionary complexes and a small part of the classic magmatic arc geology of the Alaska Peninsula. Physiographically, the map area ranges from the high glaciated mountains of the Alaska and Aleutian Ranges and the Chugach Mountains to the coastal lowlands of Cook Inlet and the Copper River delta. Structurally, the map area is cut by a number of major faults and postulated faults, the most important of which are the Border Ranges, Contact, and Bruin Bay Fault systems.

The rocks of the map area belong to the Southern Margin composite terrane, a Tertiary and Cretaceous or older subduction-related accretionary complex, and the Alaska Peninsula terrane. Mesozoic rocks between these two terranes have been variously assigned to the Peninsular or the Hidden terranes. The oldest rocks in the map area are blocks of Paleozoic age within the mélange of the McHugh Complex; however, the protolith age of the greenschist and blueschist within the Border Ranges Fault zone is not known. Extensive glacial deposits mantle the Kenai Peninsula and the lowlands on the west side of Cook Inlet and are locally found elsewhere in the map area.

This map was compiled from existing mapping, without generalization, and new or revised data was added where available.

\section{Introduction}

The Prince William Sound and Kenai Peninsula region displays a major portion of one of the world's largest accretionary complexes (Plafker and others, 1994) and a small part of the Alaska Peninsula magmatic arc. The early Tertiary and Late Cretaceous age accretionary complex is represented by rocks of the Orca Group, Valdez Group, and McHugh Complex. The accretionary complex has been known by a variety of names as our understanding of the geology of southern Alaska has evolved: the Chugach terrane (Berg and others, 1972; Nielsen and Zuffa, 1982); Chugach and Prince William terranes (Plafker and others, 1977; Jones and others, 1981); and Southern Margin Composite terrane (Plafker, 1990; Plafker and others, 1994). In addition to the rocks of the Southern Margin Composite terrane, older sedimentary and igneous rocks of the Alaska Peninsula and Hidden terranes (Wilson and others, 1985; Wilson and others, 1999) occur on both sides of Cook Inlet. The Alaska Peninsula terrane is roughly equivalent to the Peninsular terrane of Jones and others (1981). Cook Inlet is a Tertiary forearc basin lying between the modern Aleutian magmatic arc and the outboard accretionary complex.

Many sources were used to produce this geologic map. In most cases, data from available maps was combined, without generalization, and new data added where available. Bedrock geology of the Seward and Blying Sound quadrangles was largely derived from Nelson and others (1985) within the Chugach National Forest, and from Tysdal and Case (1979) elsewhere. The northeastern area of the Seward quadrangle includes revised geology by Nelson and others (1999). Surficial geology for Seward and Blying Sound quadrangles is derived from Tysdal and Case (1979). The Cordova and Middleton Island quadrangles geology was compiled and edited by Richter and others (2005) and was primarily derived from Winkler and Plafker (1993) with minor additions by T.L. Pavlis and V.B. Sisson (written commun., 2002, to D.H. Richter). Seldovia quadrangle geology was largely derived from Bradley and others (1999) with addition of surficial geology by Karlstrom (1964). Kenai quadrangle geology was derived from Karlstrom (1964), Magoon and others (1976), Bradley and Wilson (2000), and Wilson and others (2006).

\section{Geographic, Physiographic, and Geo- logic Framework}

The map area borders and includes the northern part of the Gulf of Alaska, a formerly heavily glaciated region. From west to east, the map area extends from the high glaciated mountains of the Aleutian Range to the coastal lowlands of the Cook Inlet basin to the glaciated coastal mountains surrounding Prince William Sound. Relief is generally high except for the lowlands of the western Kenai Peninsula and the alluvial flats of the Copper River on the eastern margin of the map area. The area is best known for the fjords and ice fields surrounding Prince William Sound, particularly in Kenai Fjords National Park. Redoubt Volcano, on the west side of Cook Inlet, is a prominent physiographic feature and is the highest point in the map area at 3,108 m.

Extensive glacial deposits on the Kenai Lowlands (Karlstrom, 1964) record Late Wisconsin and earlier advances; whereas glacial and volcanic deposits on the west side of Cook Inlet reflect only Late Wisconsin glaciation, Holocene readvances, and Holocene volcanism. More recently, glaciers covered much of the Prince William Sound region as a result of Little Ice Age cooling, reaching a modern maximum extent about 1900 (Grant and Higgins, 1910). Since that time, glaciers have rapidly receded: in some areas, such as in Northwestern Fiord as much as $15 \mathrm{~km}$, or as much as $20 \mathrm{~km}$ in McCarty Fiord just since 1950. Detailed mapping of the limited surficial deposits of Prince William Sound has largely not been undertaken; however, extensive studies of recent history have been undertaken as a result of the 1964 Great Alaska Earthquake (see for example, Plafker, 1969; Plafker and Page, 1994) and the 1989 Exxon Valdez oil spill.

The 1964 Great Alaska Earthquake had intense local impact and generated far-ranging tsunamis in the Pacific Basin. A brief summary of the effects of the earthquake in Alaska by Stover and Coffman (1993) described "**** vertical displacement over an area of about 520,000 square kilometers. The major area of uplift trended northeast from southern Kodiak Island to Prince William Sound and trended east-west to the east of the sound. Vertical displacements ranged from about 11.5 meters of uplift to 2.3 meters of subsidence relative to sea level. Off the southwest end of Montague Island, there was absolute vertical displacement of about $13-15$ meters. $* * *$ The zone of 
subsidence covered about 285,000 square kilometers, including the north and west parts of Prince William Sound, the west part of the Chugach Mountains, most of Kenai Peninsula, and almost all the Kodiak Island group." Much more extensive reports on the effects of the earthquake can be found in Wood (1967), Leopold (1969), and Committee on the Alaska Earthquake of the Division of Earth Sciences National Research Council (1971) and related volumes. Studies on Middleton Island and in Kenai Fjords National Park (Plafker and Rubin, 1978; Crowell and Mann, 1998) suggested a recurrence interval of 900 to 1,000 years for similar great earthquakes in this region.

The dominant geologic feature of the map area is the accretionary flysch and associated mélange of the Southern Margin Composite (SMC) terrane. These deep marine rocks record intermittent subduction-related offscraping and underplating that probably has occurred since Late Triassic time (Plafker and others, 1994). Defined as a composite terrane, the SMC includes the earlier defined Chugach and Prince William terranes as well as the Ghost Rocks Formation of the Kodiak Island region which lies between these two terranes. According to Plafker and others (1994), the Chugach terrane portion of the SMC terrane is composed of three assemblages: (1) Late Triassic to Early Jurassic greenschist and blueschist, represented for example by the Seldovia metamorphic complex; (2) late Mesozoic and older? mélange of the McHugh Complex; and (3) Late Cretaceous flysch of the Valdez Group. The Prince William terrane portion of the SMC terrane is equivalent to the Orca Group. Plafker and others (1994) assigned the Ghost Rocks Formation of the Kodiak Island area to an intervening assemblage of the SMC terrane not represented in the map area.

Two terrane names have been assigned to the rocks west of the SMC in the map area, the Peninsular terrane of Jones and Silberling (1979) and Jones and others (1981), or the Alaska Peninsula terrane of Wilson and others (1985; 1999). Over time, the usage of the term Peninsular terrane has morphed, such that the term incorporates some aspects of the definition of the Alaska Peninsula terrane (Nokleberg and others, 1994) although significant differences remain in the definitions. For example, the incorporation of the plutonic rocks of the Alaska-Aleutian Range batholith of Reed and Lanphere (1972) was a core part of the definition of the Alaska Peninsula terrane, as was the subdivision of the terrane into two related subterranes, named the Chignik and Iliamna subterranes. The batholith was and is not part of the definition of the Peninsular terrane, nor was the definition of the subterranes. Within the map area, both of the subterranes defined for the Alaska Peninsula terrane are present on the west side of Cook Inlet, separated by the Bruin Bay Fault system. The essentially batholithic Iliamna subterrane is faulted against the Chignik subterrane. Clasts in the sedimentary rocks of the Chignik subterrane become finer grained as distance from the fault increases, suggesting the fault was active during deposition (R.L. Detterman, oral commun., 1980).

The older, early Mesozoic, rocks on the east side of Cook Inlet at the extreme southwestern end of the Kenai Peninsula have traditionally been assigned to the Peninsular terrane. Aspects of these early Mesozoic rocks are similar to the oldest rocks of the Chignik subterrane of the Alaska Peninsula terrane; however, Wilson and others (1999) suggested that these
Mesozoic rocks may actually represent remnants of another, mostly lost, terrane which they called the Hidden terrane. The informally named Port Graham and Pogibshi formations of Kelley (1980) have some similarities to rocks of the Alaska Peninsula terrane; however, the Port Graham formation is lithologically distinct from the equivalent-age Kamishak Formation, and the Pogibshi formation is older than the lithologically equivalent Talkeetna Formation. Rock units assigned by Wilson and others (1999) to the Hidden terrane, such as the Seldovia metamorphic complex of Bradley and others (1999) and similar metamorphic complexes (Raspberry Schist of Roeske and others (1989), and Schist of Iceberg Lake and Schist of Liberty Creek of Winkler and others (1981) in south-central Alaska, and the Triassic Afognak pluton of Roeske and others (1989) in the Kodiak Island region have a different history than rocks more typical of the Alaska Peninsula terrane and were interpreted by Roeske and others (1989) to be part of a Late Triassic to Early Jurassic primitive island arc. Each of the metamorphic complexes, all of which are associated with the Border Ranges fault system, show evidence of blueschist facies metamorphism, whereas rocks typical of the Alaska Peninsula terrane are rarely metamorphosed. No other Triassic age plutons are known for the Alaska Peninsula terrane, another reason to separate these rocks from the Alaska Peninsula terrane. A recent $\mathrm{U}-\mathrm{Pb}$ zircon age of 204.8 $\pm 2.8 \mathrm{Ma}$ by D.C. Bradley (written commun., June 7, 2007) on the diorite of Point Bede in the Seldovia quadrangle yielded a Triassic age very similar to the Afognak pluton. Kelley (1980) describes this pluton as intruding the Pogibshi formation; as such, the age assigned to the Pogibshi formation on the basis of fossils differs from and is inconsistent with the radiometrically determined age of the intruding pluton.

In the western part of the map area the Alaska-Aleutian Range batholith of Reed and Lanphere (1973) forms the backbone of the Alaska-Aleutian Range. The volcanoes of the Aleutian magmatic arc, such as Redoubt and Iliamna Volcanoes (most of Iliamna Volcano is just west of the western edge of the map area) are emplaced on top of this backbone and young volcanic rocks represent only a small fraction of the bedrock even in the immediate vicinity of these volcanoes. East of the batholith along the Cook Inlet coast, bedrock consists of the Talkeetna Formation and overlying Jurassic sedimentary rocks of the Tuxedni Group and other sedimentary rock units as young as Tertiary (Detterman and Hartsock, 1966; Detterman and Reed, 1980; Nelson and others, 1983).

On the west side of Cook Inlet, Late Cretaceous through Triassic age rocks are products of the development and erosion of a magmatic arc. Triassic siliceous carbonates of the Kamishak Formation represent part of the basement of the magmatic arc, rocks of the Talkeetna Formation are the volcanic portion of the arc, the Alaska-Aleutian Range batholith is the plutonic core, and the sedimentary rocks of Tuxedni Group and Chinitna and Naknek Formations are the products of the erosion of the arc. It is unclear whether these sedimentary rocks represent the fore-arc basin or backarc basin of the Jurassic arc. On the basis of Reed and others' (1983) interpretation of the polarity of the arc, the sedimentary rocks would be part of the backarc. 
Structurally, the map area is cut by a number of major faults and postulated faults, in addition to many less significant faults mapped only locally. The Border Ranges Fault system is probably the most important of the major faults in the map area, separating the SMC terrane from older rocks. Plafker and others (1994) considered it the suture along which the Chugach terrane was juxtaposed against and beneath older rocks to the north; the fault system has subsequently been modified by strike-slip displacements. The Contact Fault is generally accepted as the boundary between the Chugach and Prince William terranes. Lithologically, the metasedimentary flysch units, the Valdez and Orca Groups, are very similar and the Contact Fault is a point on a continuum of decreasing metamorphic grade and deformation seaward in Prince William Sound. Another major fault system, the Bruin Bay Fault, is sub-parallel to the Cook Inlet coast east of the Alaska-Aleutian Range batholith. The Bruin Bay Fault separates the batholith from the sedimentary rocks derived from erosion of the batholith and what were the overlying volcanic rocks of the Talkeetna magmatic arc. The Bruin Bay Fault is a high-angle reverse fault and may also have leftlateral offset (Detterman and Hartsock, 1966). It was a growth fault during deposition of the Jurassic sedimentary sequence and has approximately $3 \mathrm{~km}$ of stratigraphic throw (Detterman and Hartsock, 1966). Finally, the Lake Clark Fault cutting through the northwest corner of the map area has demonstrated high-angle reverse motion (Detterman and others, 1976) and postulated right-lateral strike-slip motion ranging from $5 \pm 1 \mathrm{~km}$ (Plafker and others, 1975b) to $26 \mathrm{~km}$ in the past 34 to $39 \mathrm{~m} . \mathrm{y}$. (Haeussler and Saltus, 2005). Neither Detterman and others (1976) nor Plafker and others (1975b) saw evidence of Holocene movement.

Radiometric dating in the map area has been extensive and is still ongoing; however, the long history of geochronologic studies has resulted in some confusion. In particular, sample locations have not always been correctly reported and a number of reports of K-Ar age determinations do not reflect the change in accepted decay constants for potassium reported in Steiger and Jager (1977). As a result, we have assembled a table (table 1) of all available radiometric dates, using modern decay constants. We have also corrected sample locations, based on original data where available, and also ensured that the sample location falls within the map unit the sample is purported to date. The map unit and source reports are listed in the table.

\section{DESCRIPTION OF MAP UNITS}

[For sedimentary rock units, the stratigraphic position is reported. For igneous rock units, the age of the unit is reported. For metamorphic rock units: where stratigraphic position is reported, this is the inferred stratigraphic position for the protolith; where age is reported, this is the metamorphic age of the unit]

\section{UNCONSOLIDATED DEPOSITS}

\section{SURFICIAL DEPOSITS}

Qtf Modern tidal flat and estuarine deposits (Holocene) - Well-sorted, sub-tidal, stratified silt and some sand and local gravel deposited in shallow embayments

Qs Unconsolidated surficial deposits, undivided (Quaternary) - Mainly unsorted boulders, cobbles, gravel, sand, and silt produced, deposited, and reworked by action of wind, water, glaciers, and frost, including solifluction. Includes deposits of present streams, colluvial and alluvial fans; glaciofluvial, glaciolacustrine, and deltaic deposits; unsorted material of morainal deposits; glacial-lake silt, clay, and muskeg deposits; and locally interstratified beach gravel, sand, and clay (Tysdal and Case, 1979; Nelson and others, 1985; Winkler and Plafker, 1993). In the vicinity of the Drift River delta, this unit contains a significant proportion of volcanic debris derived from air fall, mudflows, and lahars from Redoubt Volcano and Iliamna Volcano (Till and others, 1993; Waythomas and Miller, 1999; F.H. Wilson, unpub. data). Includes artificial fill at the Drift River and West Foreland oil production facilities on the west side of Cook Inlet (Riehle and Emmel, 1980; Till and others, 1993). Locally subdivided into the following subunits:

Qat Alluvial and terrace deposits-Flood-plain alluvium and stream terrace deposits. Consists of poorly sorted to well-sorted silt, sand, pebbles, cobbles, and boulders. Also includes abandoned channel deposits in outwash above modern floodplains or underfit stream channels, inferred to be relict glacial melt water channels; may include some glacial deposits (Detterman and Hartsock, 1966; Riehle and Emmel, 1980; Till and others, 1993; Richter and others, 2005; F.H. Wilson, unpub. data). Rare natural levee deposits on deltaic or fan delta deposits occur on west side of Cook Inlet (F.H. Wilson, unpub. data)

Qls Landslide and colluvial deposits-Unsorted, angular rock debris and mud in slumps, earthdebris flows, block glides, and debris avalanches, and poorly sorted to well-sorted silt to boulders in alluvial fans and cones, and unsorted rock talus (Riehle and Emmel, 1980; Waythomas and Miller, 1999; Richter and others, 2005; F.H. Wilson, unpub. data); in vicinity of 
Redoubt Volcano and Iliamna Volcano, may include some volcanic mudflow (lahar) deposits (Riehle and Emmel, 1980); in Cordova quadrangle includes large (more than $10 \mathrm{~km}^{2}$ ) and small landslide deposits caused by the 1964 Alaska earthquake (Winkler and Plafker, 1981; Post, 1967). On west side of Cook Inlet solifluction deposits thought to be poorly sorted sand, silt, and clay derived from local upslope bedrock sources are found associated with plutonic rocks of the Alaska-Aleutian Range batholith (F.H. Wilson, unpub. data)

QsI Lacustrine, swamp, and fine silt deposits - Chiefly silt, clay, fine sand, peat, and other organic material generally of lacustrine origin (Riehle and Emmel, 1980; Richter and others, 2005; F.H. Wilson, unpub. data)

$\mathrm{Qb} \quad$ Beach deposits - Sand, gravel, and cobbles of present and former beaches, beach ridges, spits, and tidal flats (Tysdal and Case, 1979; Winkler and Plafker, 1993; Detterman and Hartsock, 1966; Riehle and Emmel, 1980; F.H. Wilson, unpub. data). Wave-deposited, coarsegrained material and driftwood along seacoast; includes fine-grained sediment in mud flats of Copper River delta; and uplifted marine terraces. Successive spit-building episodes of progressive gradation are preserved in beach sequences along coastal lowland between Cape Yakataga and Bering Glacier (Richter and others, 2005). Includes beaches uplifted by the 1964 Alaska Earthquake; most notably stranded beaches on southeastern side of Montague Island (Tysdal and Case, 1979)

Qes Estuarine deposits-Fine-grained silt rich in organic material, mud, and peat (Winkler and Plafker, 1993). Includes salt-marsh deposits of Detterman and Hartsock (1966) and grades into tidal flat deposits (Riehle and Emmel, 1980; F.H. Wilson, unpub. data). Also includes marine terrace deposits on west side of Cook Inlet (F.H. Wilson, unpub. data)

Qd Eolian deposits - Dunes consisting of well-sorted, fine-grained sand and silt aligned in longitudinal ridges on Copper River delta (Winkler and Plafker, 1993). Also includes dunes on top of river bluffs, windblown flats, and river bars (Richter and others, 2005). Includes informally named Bremner sand dunes, a large barchan field, located at confluence of Bremner and Copper Rivers (Richter and others, 2005). Includes cliff-head dunes in northern Kenai quadrangle on Turnagain Arm (Karlstrom, 1964)

Qdl Deltaic deposits-Deltaic deposits, including outwash and alluvial deposits (F.H. Wilson, unpub. data)

Qgl Glaciolacustrine deposits - Largely ephemeral glacial lake and lake-related deposits. Wellsorted, well-stratified clay, silt, and fine sand deposited in ephemeral glacial and postglacial lakes. Thought to be typically covered by several feet of muck and peat (F.H. Wilson, unpub. data). Includes stratified and locally foreset-bedded sand and gravel below $125 \mathrm{~m}$ elevation on West Foreland and from Katchin Creek to Redoubt Point; deposits are probable emerged delta and glaciolacustrine deposits (Riehle and Emmel, 1980). Also includes active outwash fans (Riehle and Emmel, 1980). On Kenai Peninsula, includes hanging delta deposits in former proglacial lakes associated with the last glacial maximum (Karlstrom, 1964)

Qm Glacial deposits, undivided - Glacial drift consisting of sand, gravel, and boulders. Includes ground, recessional, end, medial, and lateral moraine deposits, as well as colluvium, talus, landslide debris, alluvium, and silt, locally (Riehle and Emmel, 1980; F.H. Wilson, unpub. data). Includes active and recently active rock glaciers consisting chiefly of rubble and coarse rock debris (F.H. Wilson, unpub. data) and fresh, poorly sorted debris on surfaces of glaciers (Detterman and Hartsock, 1966; Winkler and Plafker, 1993). In the vicinity of Mount Redoubt and Mount Iliamna, may include a significant component of ash and other air-fall debris from eruptions (F.H. Wilson, unpub. data). Locally subdivided into the following subunits:

Qag Drift of Neoglacial age (Holocene) - Neoglacial terminal, recessional, lateral, and ground moraine consisting of unsorted boulders, cobbles, gravel, and sand deposited during retreat of glaciers. Includes deposits of the Tunnel and Tustumena Stades (Detterman and Hartsock, 1966); Tunnel Stade moraines are barren deposits as much as $1.6 \mathrm{~km}$ in front of present glaciers. Tustumena Stade deposits consist of partially dissected spruce- and brush-covered moraine 1.6 to $10 \mathrm{~km}$ in front of present glaciers (Detterman and Hartsock, 1966). On the Kenai Peninsula, includes unmodified moraine deposits which may be mantled by loess, generally 2 to $6 \mathrm{ft}$ thick (Karlstrom, 1964). Locally includes kames and outwash proximal to present glaciers (Richter and others, 2005)

Qao Outwash of the Neoglacial age (Holocene) - Outwash deposits associated with modern and Holocene glaciers (Karlstrom, 1964; F.H. Wilson, unpub. data). Consist of poorly sorted to 
well-sorted silt, sand, and gravel in terraces and outwash fan plains (Detterman and Hartsock, 1966; Riehle and Emmel, 1980)

Qgn Glacial deposits of the Naptowne and Brooks Lake Glaciations (Pleistocene) - Terminal, recessional, lateral, medial, and ground moraine and other deposits. Moderately weathered along Cook Inlet shoreline; heavily spruce and brush covered (Detterman and Hartsock, 1966; F.H. Wilson, unpub. data). Internal contacts on west side of Cook Inlet reflect subdivisions of the Brooks Lake Glaciation; the Iliuk, Newhalen, and Iliamna advances. On east side of Cook Inlet, includes prominent and little modified morainal deposits, mantled by 2 to $6 \mathrm{ft}$ of loess (Karlstrom, 1964)

Qgno Outwash and valley train deposits (Pleistocene)—Silt, sand, and gravel sloping away from Naptowne age moraines (unit Qgn) on Kenai Peninsula (Karlstrom, 1964) and Brooks Lake age moraines on west side of Cook Inlet (F.H. Wilson, unpub. data)

Qog Older glacial deposits (Pleistocene) - Includes prominent, but modified morainal deposits of the Knik and Eklutna Glaciations. Deposits widely exposed north of Homer on Kenai Peninsula (Karlstrom, 1964). On Kenai Peninsula, Knik and Eklutna age moraines are terraced below approximately $228 \mathrm{~m}$ (750 ft), reflecting deposition in proglacial lakes. Also includes pebble- and boulder-bearing diamicton observed at one upland location at West Foreland and in sea cliffs along West Foreland, and from Katchin Creek south to near Redoubt Point (Riehle and Emmel, 1980)

Qogo Outwash associated with older glacial deposits (Pleistocene) - Silt, sand, and gravel graded to moraines of Knik and Eklutna age on Kenai Peninsula (Karlstrom, 1964)

Qch Moraine of the Caribou Hills Glaciation (Pleistocene) - Highly modified morainal deposits in Caribou Hills and exposed as remnant deposits elsewhere on Kenai Peninsula

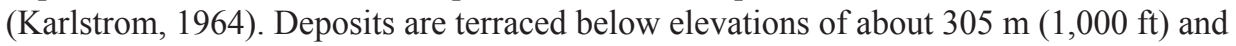
discontinuously mantled by proglacial lake sediment deposits (Karlstrom, 1964)

\section{ROCK UNITS WEST OF THE BORDER RANGES FAULT SYSTEM}

\section{BEDDED ROCKS}

Tkn Kenai Group, undivided (Pliocene to Oligocene) - Coal-bearing clastic unit consisting of, in descending order, the Sterling, Beluga, and Tyonek Formations, and Hemlock Conglomerate in the vicinity of Cook Inlet. According to Calderwood and Fackler (1972), unit is at least 8,000 m thick in subsurface of Cook Inlet. Calderwood and Fackler (1972) included West Foreland Formation within the Kenai Group; however, West Foreland Formation was separated as a distinct unit by Magoon and others (1976). Subdivided into:

Ts Sterling Formation (Pliocene and Miocene) — Weakly lithified massive sandstone, conglomeratic sandstone and interbedded claystone; includes interbedded lignitic coals typically less than $1 \mathrm{~m}$ thick in upper part of unit, but may be as much as $3 \mathrm{~m}$ thick in lower part of unit (Calderwood and Fackler, 1972). According to Flores and others (1997, cited in Bradley and others, 1999), sandstone grades upward from coarse grained to very fine grained in trough crossbedded sequences; siltstone is typically ripple-laminated and contains roots or burrows. Bradley and others (1999) indicated that only the lowest $700 \mathrm{~m}$ of the more than 3,000-m-thick Sterling Formation is exposed at the surface, consisting of siltstone, mudstone, carbonaceous shale, lignite coal, and minor volcanic ash. Triplehorn and others (1977) and Turner and others (1980) reported number of K-Ar and fission-track age determinations from ash partings within coal beds within unit (table 1). Dates range from $4.2 \pm 1.4$ to $8.9 \pm 1.0 \mathrm{Ma}$; some older reported ages were interpreted to result from contamination by detrital material (Turner and others, 1980)

Tb Beluga Formation (Miocene) - Nonmarine, interbedded, weakly lithified sandstone, siltstone, mudstone, carbonaceous shale, coal, and minor volcanic ash (Bradley and others, 1999). Calderwood and Fackler (1972) reported a distinctive feature of Beluga Formation is its lack of massive sandstone beds and massive coal seams that characterize underlying Tyonek Formation; however, lignitic to subbituminous coal seams can be as much as $4 \mathrm{~m}$ thick in upper part of Beluga Formation. Contact between Beluga and overlying Sterling Formation may be an unconformity (Calderwood and Fackler, 1972), but in any case it can be difficult to pinpoint contact (Calderwood and Fackler, 1972; Turner and others, 1980). Triplehorn and others (1977) and Turner and others (1980) reported a number of K-Ar and fission-track age determinations from ash partings within coal beds ranging from $7.2 \pm 1.3$ to $12.9 \pm 5.1 \mathrm{Ma}$ (table 1 ) 
Tty Tyonek Formation (Miocene and Oligocene) — Nonmarine conglomerate and subordinate sandstone, siltstone, and coal within the map area as described by Bradley and others (1999). However, in general, the Tyonek Formation is identified by the presence of massive sandstone beds and lignitic to subbituminous coal beds as much as $9 \mathrm{~m}$ thick (Calderwood and Fackler, 1972). Contact with overlying Beluga Formation is believed to be a disconformity where sandstone beds and coal beds become markedly thinner (Calderwood and Fackler, 1972). Plant fossils representing Seldovian Stage of early and late Miocene age as well as plant fossils representing Angoonian Stage of Oligocene age provide age control (Wolfe and Tanai, 1980)

Th Hemlock Conglomerate (Oligocene) - Sandstone, conglomerate, and siltstone assigned to unit, as defined by Calderwood and Fackler (1972), occurs only in vicinity of Harriet Point in Kenai quadrangle on west side of Cook Inlet. On the basis of description in Detterman and others (1976), unit inferred to consist of fluvial conglomeratic sandstone and conglomerate containing minor interbeds of siltstone, shale, and coal. Magoon and others (1976) mapped these rocks in a unit consisting of the combined Tyonek Formation and Hemlock Conglomerate, whereas Detterman and others (1976) assigned these rocks to the Hemlock Conglomerate. Hemlock Conglomerate is lithologically transitional with Tyonek Formation, leading to some confusion. Hemlock Conglomerate is best known from the subsurface from well logs and not from surface mapping. Plant fossils suggest an Oligocene age; Wolfe and Tanai (1980) suggested early Oligocene and Wolfe (cited in Detterman and others, 1996) suggested late Oligocene for rocks assigned to this unit south of the map area. Wolfe and Tanai (1980) suggested rocks at Harriet Point may be isochronous with beds considered typical of the Tyonek Formation

Twf West Foreland Formation (Eocene and Paleocene) - Exposed only on west side of Cook Inlet, unit consists of tan to light-yellow-brown cobble conglomerate interbedded with lesser sandstone, laminated siltstone, and silty shale (Detterman and Hartsock, 1966). Thin coal beds are interbedded with the siltstone and shale. Detterman and Hartsock (1966) also described a lenticular bed of "carbonaceous ashstone breccia" that may have been referred to as obsidian by Martin and Katz (1912). However, Detterman and Hartsock (1966) indicate that along with quartz and feldspar grains and probably glass shards, the lenticular bed also contains plant fragments and is clearly of sedimentary origin. Clasts in conglomerate are mainly rounded to sub-rounded quartz diorite, volcanic rock, argillite, sandstone, siltstone, quartzite, tuff, and coal fragments. Intrusive and volcanic rock fragments each make up about 35 percent of the conglomerate clasts. Medium- to coarse-grained arkosic sandstone forms the matrix of the conglomerate as well as forming distinct lenticular beds. Siltstone and shale interbedded with conglomerate is a very fine grained sub-arkosic equivalent of the sandstone. Originally mapped as Kenai Formation by Detterman and Hartsock (1966), Calderwood and Fackler (1972) raised unit to group status and subdivided it into formations. Rocks here were assigned to the West Foreland Formation. West Foreland was assigned an Oligocene age by Kirschner and Lyon (1973) and later reassigned an early Eocene and late Paleocene age by Magoon and others (1976). Dating of zircon from an interbedded tuff about $1 \mathrm{~m}$ thick from north of map area yielded $43 \mathrm{Ma}$ age (middle Eocene) (P.J. Haeussler and D.W. Bradley, USGS, oral commun., 2005). West Foreland Formation was removed from the Kenai Group because it is separated from overlying Hemlock Conglomerate by a major unconformity (Magoon and Egbert, 1986). Detterman and Hartsock (1966) described lower contact of these rocks as an angular unconformity with the Upper Jurassic Naknek Formation; subsequent work by Magoon and others (1980) showed there is a nonmarine Upper Cretaceous sedimentary unit between the West Foreland and Naknek Formations. Those Cretaceous sedimentary rocks are shown here as unit Ksm

Ksm Saddle Mountain section of Magoon and others (1980) (Upper Cretaceous, Maastrichtian)-Nonmarine sandstone, conglomerate, and minor siltstone and coal northeast of Chinitna Bay in an 83-m-thick section (Magoon and others, 1980). Consists dominantly of fine- to medium-grained sandstone that becomes finer grained upward. Unit is generally massive though some crossbedded sections are present. Sandstone is soft and friable except where calcite cemented. Conglomerate contains volcanic and plutonic rock boulders as much as $30 \mathrm{~cm}$ in diameter in a sandy matrix. Coal beds, which tend to occur in upper part of the section, are as much as $2.7 \mathrm{~m}$ thick and locally have underclay ("undersoils", Magoon and others, 1980). Siltstone is most abundant in the middle part of the section. Sporomorphs 
Cranwellia striata (Couper) Srivastava, Balmeisporites spp., Wodehouseia spinata Stanley, Proteacidites spp., Aquilapollenites bertillonites Funkhouser, A. reticulatus Mtchedlishvili, A delicatus Stanley (Magoon and others, 1980) indicate a Maastrichtian age. Unit was assigned to the Kaguyak Formation by Bradley and others (1999), but is mapped separately here because lithology and depositional environment are distinctly different from the Kaguyak Formation. Unit overlies Jurassic Naknek Formation with angular unconformity and is in turn overlain by rocks of the West Foreland Formation with angular unconformity

Naknek Formation (Upper Jurassic; Tithonian to Oxfordian)_ Originally named Naknek Series by Spurr $(1900$, p. 169-171, 179, 181) for exposures at Naknek Lake on the Alaska Peninsula. Largely consists of sandstone, conglomerate, and siltstone having a primarily plutonic provenance. Unit is widespread in southern Alaska, exposed in a long belt from south-central Alaska (Wilson and others, 1998) to southwestern end of the Alaska Peninsula (Wilson and others, 1999), a distance of about 1,150 km (Detterman and others, 1996). The aggregate thickness of the individual members exceeds $3,000 \mathrm{~m}$, though average thickness is more typically 1,700 to 2,000 $\mathrm{m}$ (Detterman and others, 1996). Megafossils, particularly the pelecypod Buchia (Detterman and Reed, 1980, p. B38; J.W. Miller, written commun., 1982 to 1988), are common, and fauna, which also includes ammonites, indicate an age range of Oxfordian to late Tithonian (Late Jurassic). Detterman and others (1996; see also, Detterman and Hartsock, 1966; Martin and Katz, 1912) have subdivided Naknek Formation into members of which the following appear in the map area:

Jnp Pomeroy Arkose Member (Kimmeridgian and Oxfordian?) - Massive, light-gray, mediumto coarse-grained arkose containing many interbedded thin beds of dark-gray to brownish siltstone and pebble conglomerate (Detterman and Hartsock, 1966). The sandstone is rich in quartz (40-45 percent), sodic feldspar (30-35 percent), and contains 15-20 percent hornblende and tourmaline. Volcanic lithic fragments make up 2-3 percent of unit. Grains are sub-angular to sub-rounded. The matrix is generally clay, but locally, is tuffaceous. Siltstone is mineralogically distinctive from the arkose and resembles the graywacke of older units according to Detterman and Hartsock (1966); we interpret this to indicate the siltstone contains a higher proportion of volcanic- and sedimentary-sourced components. Detterman and Hartsock (1966) indicated that most sections of the Pomeroy Arkose Member have a 70- to 350-ft-thick (21 to $113 \mathrm{~m}$ ) gray, medium-bedded to massive, arenaceous siltstone horizon, usually in the lower part of the member. The Pomeroy Arkose is sparsely fossiliferous containing Lytoceras, Phylloceras, and Buchia concentrica, suggesting an age no younger than early Kimmeridgian. Detterman and Hartsock (1966) suggested that the nearby Jurassic part of the Alaska-Aleutian Range batholith was the source for unit and the subangular character of the easy-to-destroy grains (hornblende, tourmaline, and feldspar) indicate short transport and rapid burial

Jnst Snug Harbor Siltstone Member (Kimmeridgian and Oxfordian) —Dominantly massive to thin-bedded, dark-gray to black siltstone; minor calcareous gray sandstone beds (Detterman and Hartsock, 1966). Hard gray limestone concretions and lenses are locally abundant; rare thin layers of volcanic ash and tuff are found locally (Detterman and Hartsock, 1966). Deposited in moderately deep water, well below wave base and above carbonate compensation depth, in a basin having restricted circulation (Detterman and others, 1996). Unit is the lowest abundantly fossiliferous member of the Naknek; most common fossils present are of the genus Buchia, including Buchia concentrica, as well as the ammonites Amoeboceras, Phylloceras, and Perisphinctes

Jnn Northeast Creek Sandstone Member (Oxfordian) _ Light-gray, thin-bedded to massive arkosic sandstone, graywacke, and siltstone. Originally called the "lower sandstone member" by Detterman and Hartsock (1966) who considered unit to have only local significance. Later work on the Alaska Peninsula (Detterman and others, 1996) showed that the lateral equivalent of this unit, which they named the Northeast Creek Sandstone Member, is present along the entire length of the Alaska Peninsula. According to Detterman and Hartsock (1966), some beds have a tuffaceous matrix, zones of small pebbles, and thin beds of arenaceous siltstone. Fossils are most common in lower part of unit and include ammonites, particularly Cardioceras, but also Phylloceras and Lytoceras. Detterman and Hartsock (1966) assigned a latest Callovian and early Oxfordian age to unit based Cardioceras martini in lower part of the member and its association with Cardioceras distans, which then without Cardioceras martini continues to top of member. Detterman and others (1996) restricted 
unit to Oxfordian based on reinterpretation of available information. Pelecypods, including Pleuromya, Quenstedtia, Oxytoma, Thracia, and Astarte, and gastropods, echinoids, and belemnites are present but not common (Detterman and Hartsock, 1966). Lower contact intertongues with Chisik Conglomerate Member; upper contact is gradational with overlying Snug Harbor Siltstone Member

Jnc Chisik Conglomerate Member-Massive to thick-bedded conglomerate and interbedded, crossbedded, quartzose sandstone. Clasts, as large as $2 \mathrm{~m}$, are mainly granitic rocks, but up to 20 percent are metamorphic and volcanic rocks (Detterman and others, 1996). In map area is mainly restricted to area adjacent to Tuxedni Bay. A K-Ar age determination (table 1, sample 62Ale 6e) on a quartz diorite cobble yielded a protolith age of $156.6 \mathrm{Ma}$ on biotite and 159.7 Ma on hornblende (Detterman and others, 1965)

Chinitna Formation (Middle Jurassic, Callovian) - Massive gray arenaceous siltstone. Unit is best exposed along west coast of Cook Inlet where it is subdivided into two members; upper Paveloff Siltstone Member and lower Tonnie Siltstone Member (Detterman and Hartsock, 1966). Unit is a partial age equivalent of the Shelikof Formation of the Alaska Peninsula (Detterman and others, 1996). Paveloff Siltstone and Tonnie Siltstone Members described below:

Jcp Paveloff Siltstone Member-Massive dark-gray arenaceous siltstone in upper part, thick sandstone unit at base (Detterman and Hartsock, 1966). Large ellipsoidal concretions and lenticular beds of limestone occur throughout and thin interbeds of sandstone occur in the siltstone. A few siltstone beds contain abundant finely disseminated pyrite, causing beds to weather rusty brown. Siltstone is well-indurated and uppermost part is thin-bedded and fractures into angular fragments. Graywacke sandstone of lower unit is "*** thin bedded to massive, locally lenticularly bedded, fine to coarse grained, gray to greenish gray" (Detterman and Hartsock, 1966, p. 43). Limestone concretions and interbeds are common; very dark-gray on fresh surfaces, but weather buff to cream colored. Locally the limestone is bioclastic (Detterman and Hartsock, 1966). Many non-diagnostic pelecypods and gastropods have been collected from lower sandstone (Detterman and Hartsock, 1966), whereas a wide variety of ammonites have been collected from siltstone and limestone concretions higher in the section. Many genera of ammonites, including Cadoceras, Stenocadoceras, Pseudocadoceras, Kepplerites, Kheraiceras, and Lilloettia, have been collected (Detterman and Hartsock, 1966), indicating a Callovian age, although uppermost zone of the Callovian has not been identified. Paveloff Siltstone Member is the age equivalent of Shelikof Formation of the Alaska Peninsula; Shelikof contains a higher proportion of coarse volcanic debris (Detterman and others, 1996)

Jct Tonnie Siltstone Member-Massive dark-gray to brownish-gray arenaceous siltstone; weathers brownish-gray to red-brown (Detterman and Hartsock, 1966). Numerous small yellowish-brown weathering limestone concretions occur in parallel bands and randomly throughout section. Limestone concretions are generally ovoid, as much as $12-13 \mathrm{~cm}$ in diameter, extremely hard, and commonly fossiliferous (Detterman and Hartsock, 1966). Thin, fine-grained, greenish-gray sandstone interbeds occur in the siltstone; a more massive sandstone unit is found at the base of section. Sandstone interbeds are compositionally similar, but coarser grained than the siltstone. A thick $(6-30 \mathrm{~m})$ sandstone bed at base of the unit is medium bedded to massive, fine to medium grained, and grayish brown. On Chisik Island, a thick $(65 \mathrm{~m})$ channel conglomerate, consisting mainly of volcanic rock cobbles and boulders, is at base of the section. "The Chisik Island section also contains numerous thin beds of volcanic ash (Detterman and Hartsock, 1966, p. 41)." Unit is abundantly fossiliferous, yielding many mollusks, particularly ammonites, including Paracadocreas, Pseudocadoceras, Phylloceras, Lilloettia, Kheraiceras, Kepplerites, and Xenocephilites. Numerous pelecypods and rare belemnites, gastropods and brachiopods, with the ammonites indicate an early Callovian age (Detterman and Hartsock, 1966)

Tuxedni Group (Middle Jurassic, Bathonian to Aalenian) - Light- to dark-gray and green marine graywacke, conglomerate, siltstone, and shale (Detterman and Hartsock, 1966). Graywacke ranges from feldspathic to lithic to laumontitic; conglomerate composed mainly of volcanic clasts in graywacke matrix. Unit is locally subdivided into (from oldest to youngest): Red Glacier Formation, Gaikema Sandstone, Fitz Creek Siltstone, Cynthia Falls Sandstone, Twist Creek Siltstone, and Bowser Formation. Descriptions below are derived from Detterman and Hartsock (1966); age revised to Bathonian to Bajocian by Imlay and 
Detterman (1973) and to lower Bathonian to Aalenian by Detterman and Westermann (1992)

Jtb Bowser Formation (Bathonian) - Heterogeneous assemblage of sandstone, conglomerate, shale and siltstone characterized by rapid facies changes (Detterman and Hartsock, 1966). Massive light- to dark-gray sandstone and conglomerate are dominant lithologic types on Iniskin Peninsula. The sandstone and the conglomerate matrix are coarse grained and composed of angular fragments of feldspar and quartz, with biotite, augite, and magnetite as common accessory minerals. Light-gray sandstone is commonly calcareous and contains numerous coquina beds composed almost entirely of pelecypods Retroceramus (formerly most Middle Jurassic Alaska inoceramids were referred to the genus Inoceramus) and Trigonia and is also interbedded with dark-gray sandstone. Clasts in the conglomerate are dominantly felsic volcanic rocks and basalt, but include about 10 percent granitic rocks. Massive to thin-bedded, medium- to coarse-grained, dark-brownish gray siltstone beds weather to light brown. Siltstone beds as much as $100 \mathrm{~m}$ thick are interbedded with the conglomerate and sandstone; north of Chinitna Bay siltstone beds as much as $250 \mathrm{~m}$ thick form the dominant lithology of the Bowser Formation. Lenticular limestone concretions containing ammonites are common north of Chinitna Bay. Overall thickness ranges from 380 to 560 m. Abundantly fossiliferous, containing ammonites and pelecypods. Most recently dated as late Bajocian to early Bathonian by Detterman and Westermann (1992)

Twist Creek Siltstone (Bajocian) - Soft, poorly consolidated, thin-bedded to massive siltstone and silty shale as much 125 m thick (Detterman and Hartsock, 1966). Dark-gray siltstone weathers to dark rusty brown, and contains many thin beds of volcanic ash that weather bright orange. Small, commonly fossiliferous, limestone concretions common throughout. Abundant ammonite fauna include Oppelia (Liroxyites), Megasphaerceras, Leptosphinctes, Lissoceras, and Normannites (Dettermanites), but is restricted to limestone concretions

Jtc Cynthia Falls Sandstone (Bajocian?)-Massive to thick-bedded graywacke sandstone and pebble conglomerate about $200 \mathrm{~m}$ thick (Detterman and Hartsock, 1966). Medium- to coarse-grained, greenish-gray to dark-green sandstone; graded bedding; weathers mottled light-gray due to presence of zeolites. Sandstone consists mainly of angular fragments of feldspar and volcanic rocks in a compositionally similar silt-size matrix. Pebble conglomerate, in thin lenticular beds within the sandstone, is well sorted within individual beds. Clasts consist of "red and green felsitic volcanic rocks, aphanitic igneous rocks, and a few metasedimentary rocks that are primarily dark-gray quartzite" (Detterman and Hartsock, 1966, p. 32). Coarse-grained siltstone is interbedded with the sandstone and may contain a few limestone concretions. Siltstone makes up 10 to 20 percent of the formation. Like the underlying Fitz Creek Siltstone and Gaikema Sandstone, unit is coarsest grained in vicinity of Gaikema Creek and finer grained away from creek area. Fossils relatively uncommon in unit, thought in part due to rapid deposition in a nearshore environment. Fauna includes ammonites Chondroceras and Stephanoceras, as well as the pelecypods Retroceramus (formerly Inoceramus) sp. and Mytilus sp.

Jtf Fitz Creek Siltstone (middle Bajocian) -Massive, bluish dark-gray, arenaceous, coarse- to fine-grained siltstone up to $400 \mathrm{~m}$ thick; commonly weathers rusty orange and contains many small limestone concretions (Detterman and Hartsock, 1966). Fine-grained sandstone and, locally, conglomerate is interbedded. In upper part of unit, siltstone could possibly be called silty shale. Unit is coarsest in vicinity of Gaikema Creek and rapidly becomes finer grained in all directions away from Gaikema Creek. Unit is abundantly fossiliferous and is lowest unit of Tuxedni Group where ammonites are more numerous than pelecypods. A few non-diagnostic brachiopods are also present. Ammonites include Normannites, Teloceras, and Chondroceras and many other genera; pelecypods include Retroceramus (formerly Inoceramus) and Pleuromya, both in forms distinctly different than those found in lower parts of Tuxedni Group

Jtg Gaikema Sandstone (lower middle Bajocian)—Resistant, cliff-forming, massive to thinbedded graywacke sandstone and cobble conglomerate; 150 to $260 \mathrm{~m}$ thick (Detterman and Hartsock, 1966). Sandstone commonly occurs in graded beds up to $3 \mathrm{~m}$ thick, whereas conglomerate is well sorted within individual beds and rarely graded (Detterman and Hartsock, 1966). Conglomerate is confined to Iniskin Peninsula; clasts consist of "red and green felsitic volcanic rocks, aphanitic igneous rocks, and minor metasedimentary rocks" (Detterman and Hartsock, 1966, p. 26), all thought to be derived from the Talkeetna For- 
mation. Rare granitic clasts are the first appearance of rocks presumably derived from the Alaska-Aleutian Range batholith. Siltstone, occurring mainly as thin interbeds in sandstone, is thin bedded to massive, generally coarse silt to sandy, gray to olive gray, and weathers brownish to rusty brown. In general, siltstone constitutes less than 10 percent of unit, though locally, it can constitute as much as 40 percent. Siltstone apparently does not occur in close proximity to conglomeratic parts of the formation (Detterman and Hartsock, 1966). Unit is fossiliferous throughout, containing pelecypods Meleagrinella, Trigonia, and Retroceramus (formerly Inoceramus) and ammonites Witchellia(?), Stephanceras and locally, Sonninia (Papilliceras), Lissoceras, and Emileia. Carbonized plant remains are locally present

Jtrg Red Glacier Formation (lower middle Bajocian to lower Bajocian) - Thin-bedded to massive, dark-gray to moderate olive-gray, highly arenaceous siltstone, weathers red brown and locally contains lenticular interbeds and concretions of reddish-gray, dense limestone and very minor coal seams (Detterman and Hartsock, 1966). Underlying siltstone is light-tan to buff arkosic sandstone and thick, black, silty to arenaceous, very fissile shale. Siltstone constitutes about 40 percent of unit, concentrated in upper part; sandstone about 25 percent, and shale the remainder. Overall thickness ranges from 600 to as much as 2,000 m. Fossils most abundant in upper part of unit; no fossils known from lowermost part (as much as $600 \mathrm{~m}$ ) of unit. Pelecypods include Meleagrinella, Trigonia, Retroceramus (formerly Inoceramus), Camptonectes, and Pleuromya. Ammonites occur in two distinct faunal assemblages; lower assemblage faunal zone includes Erycites, Tmetoceras, and Pseudolioceras and ranges from 450 to 1,400 $\mathrm{m}$ below the top of formation. Upper assemblage in upper $400 \mathrm{~m}$ of formation includes Soninia, Emileia, Parabigottes and in uppermost 150 m, Papilliceras, Strigoceras, Lissoceras, Stephanoceras, Stemmatoceras, and Skirroceras

Jtk Talkeetna Formation, undivided (Lower Jurassic)_Bedded volcanic rocks widely distributed in Seldovia and Kenai quadrangles west of Cook Inlet. Where undivided, unit consists of flows, breccia, tuff, and agglomerate and locally interbedded minor sandstone and shale, all typically somewhat altered or metamorphosed (Detterman and Hartsock, 1966; Detterman and Reed, 1980). Detterman and Hartsock (1966) formally divided unit into three members. Within map area, Talkeetna Formation is locally subdivided, from top to bottom, into the Horn Mountain Tuff, Portage Creek Agglomerate, and Marsh Creek Breccia Member, described below:

Jtkh Horn Mountain Tuff Member-Bedded tuff and tuffaceous feldspathic sandstone, locally containing porphyritic andesite flows. Tan, red, green, purple, or mottled-color, thin-bedded to massive and fine- to coarse-grained bedded tuff (Detterman and Hartsock, 1966). Locally, tree stumps preserved within tuff beds, indicating subaerial deposition. However, thin-bedded laminated units that have graded bedding and contain rare belemnite fragments indicating some parts of unit are marine. Measured thickness is as much as $870 \mathrm{~m}$ (Detterman and Hartsock, 1966). Above mentioned belemnites and plant fragments occur near the top of unit; fossils are not age diagnostic. In the Talkeetna Mountains north of the map area, fossils in upper part of Talkeetna Formation, which is considered correlative to rocks of the Horn Mountain Tuff Member, indicate a late Pliensbachian and Toarcian (Early Jurassic) age (Arthur Grantz, oral commun., 1963, cited in Detterman and Hartsock, 1966)

Jtkp Portage Creek Agglomerate Member-Reddish fragmental volcanic debris, primarily rounded volcanic bomb-like fragments and lapilli tuff; grading to fine-grained tuff, clastic sedimentary rocks and flows northward in map area (Detterman and Hartsock, 1966). Interbedded flows, tuff, and sedimentary rocks are thicker than in the underlying Marsh Creek Breccia Member, which suggested to Detterman and Hartsock (1966) a decrease in violent volcanism in the source area. These rocks are generally more felsic, although commonly described as andesitic (Detterman and Hartsock, 1966), than those of the Marsh Creek Breccia Member and their distribution suggests a separate source (Detterman and Hartsock, 1966). Estimated thickness is between 685 and $870 \mathrm{~m}$. No known fossil control

Jtkm Marsh Creek Breccia Member-Massive dark-green to green volcanic breccia having a tuff matrix (Detterman and Hartsock, 1966). Consists of angular fragments of aphanitic pink and green volcanic rocks ranging in size from $1 \mathrm{~cm}$ to nearly $1 \mathrm{~m}$ and in general, fine upward. Interbedded flows of andesite and basalt, thought to be partly submarine, are common and increase in abundance and thickness southward (Detterman and Hartsock, 1966; Detterman and Reed, 1980). Bedded tuff is locally important, thickest in southern exposures, and coarser in the more northern exposures. Unit has an estimated minimum overall thickness of 
$1,000 \mathrm{~m}$, although no complete section has been measured and sections that have been measured are cut by extensive faulting. Locally, unit has obscure contact relation with plutons of the Alaska-Aleutian Range batholith or has been assimilated into the Holocene magma chamber under Iliamna Volcano (Detterman and Hartsock, 1966). No fossils are known from unit in map area and age is inferred based on correlations with rocks in the Talkeetna Mountains type area north of map area

Jp Pogibshi formation of Kelley (1980), undivided (Lower Jurassic, Sinemurian to Hettangian and older?) - Informally named Pogibshi formation of Kelley (1980); exposed on east side of Cook Inlet. Consists of volcaniclastic rocks interbedded with small amounts of limestone, coal, and tuffaceous argillite. Kelley (1980) divided unit into three members on the basis of rock type, modal composition, and depositional texture. Stratigraphically lowest member, the Dangerous member, consists of volcaniclastic breccia, conglomerate, and sandstone and is in depositional contact with Kelley's Port Graham formation (下pg herein). Locally tuffaceous dark-gray sedimentary rocks in Dangerous member make it hard to distinguish from Port Graham formation. July member consists of dacitic pyroclastic rocks, tuffaceous sandstone, granule conglomerate, and mudstone. Kelley (1980) indicated that the high quartz content and abundance of glassy debris help to distinguish this member from other members of his Pogibshi formation. The uppermost Naskowhak member, consists of greenish-gray tuffaceous mudstone and siltstone, and tuff. Locally, the basal part of Naskowhak member includes laterally extensive coal-bearing units. The coal-bearing units help distinguish the Pogibshi formation of Kelley (1980) from the otherwise lithologically similar Talkeetna Formation on the west side of Cook Inlet. The Pogibshi formation of Kelley (1980) is reportedly intruded by tonalite of Dogfish Bay of Bradley and others (1999) (kdt) and possibly by the diorite of Point Bedeof Bradley and others (1999) ( $\mathrm{kdt}$ ); if so the recently determined Triassic age on the diorite (D.C. Bradley, oral commun., 2007) may indicate that the Pogibshi is, in part, significantly older than the Talkeetna Formation. Martin $(1915,1926)$ reported a diverse Lower Jurassic fauna along the coast southwest of Seldovia. Bradley and others (1999) erroneously attributed these Jurassic fossil collections by Martin (1915) to the Port Graham formation of Kelley (1980); however, those collections were from localities within the outcrop area Bradley and others (1999) assigned to the Talkeetna Formation, which we reassign back to the Pogibshi formation of Kelley (1980). Fossils noted in two Martin reports $(1915,1926)$ include several species of scleractinian corals, numerous bivalves (mostly pectinaceans), gastropods, and ammonites. A brief visit by R.B. Blodgett (written commun., 2007) to an early Sinemurian age section exposed about $3 \mathrm{~km}$ west of Seldovia showed unit contains numerous pectinacean bivalves, gastropods, and several species of scleractinian corals. The bivalves were found both as articulated and disarticulated specimens, and most appear to belong to the genus Weyla, a Lower Jurassic index fossil found primarily along the western coast of North and South America. Lower Jurassic ammonites from these same rocks were discussed and, in part, illustrated in Imlay (1981), who recognized both Sinemurian and Hettangian age fossil assemblages. A fossil determination by A.K. Armstrong of a collection made by J.S. Kelley yielded poorly preserved Permian corals (sample 75JK-151B, www.alaskafossil.org). Due to the poor state of preservation of the coral material, we tentatively discount this collection until further material can be collected and identified from this locality. Connelly (1978) and Connelly and Moore (1979) suggested correlation of these rocks with the Upper Triassic Shuyak Formation of the Afognak Island, which is intruded by the Triassic age Afognak pluton (see also Wilson and others, 2005)

kpg Port Graham formation of Kelley (1980) (Upper Triassic, Norian) — Dominantly dark-gray, carbonaceous limestone and silty limestone containing varying amounts of silica cement (Kelley, 1980). Fine-grained, dark-gray siliceous to limy mudstone, silty sandstone, and dark-gray to dark-olive-gray, thin- to medium-bedded chert having mudstone partings are also common lithologies according to Kelley (1980). Limy beds tend to be most common in lower (middle Norian) part of unit (R.B. Blodgett, written commun., 2007, and unpublished data of Humble Oil Company [now Exxon-Mobil] reported by R.B. Blodgett); whereas upper part (of late Norian age) is composed of considerably more volcaniclastic fragment-rich beds and shaly beds. The volcaniclastic fragment-rich beds contain a diverse, but uncommon molluscan fauna consisting of both bivalves and gastropods, while the shaly beds tend to have a monotaxic fauna of monotid bivalves. Fossils are locally abundant, as reported by Kelley (1980), and are mostly thin shelled mollusks, but also include 
corals, echinoids, ammonites, and trace fossils. Martin and others (1915) and Martin (1926) reported bivalves Halobia $\mathrm{cf}$. H. superba Mojsisovics, Pseudomonotis subcircularis Gabb (this species is now referred in the genus Monotis), Nucula?, and the coral Astrocoenia? sp. The Halobia cf. H. superba was suggested by Martin to possibly indicate a Carnian age (this species was later re-identified as belonging to middle Norian age species of Halobia by Silberling and others, 1997), while Monotis subcircularis indicates a late Norian age. Silberling and others (1997) provided a detailed analysis of known Late Triassic bivalve fauna known from the Port Graham area and reported middle Norian age Halobia lineata and $H$. dilitata were found in collections reported by Martin (1915; USGS Mesozoic localities 6380 and 6382, respectively). Silberling and others (1997) reported two different species of Late Triassic Monotis: Monotis (Pacimonotis) subcircularis and Monotis (Monotis) alaskana, as well as the late middle Norian ammonite Steinmannites. Kelley (1984) and Bradley and others (1999) assigned an upper age limit of Early Jurassic, although no Early Jurassic fossils have been found in unit: Early Jurassic fossils do occur in upper part of the overlying Pogibshi formation of Kelley (1980)

\section{METAMORPHIC ROCKS}

JPk Kakhonak Complex (Lower Jurassic to Permian? or older?) — The Kakhonak Complex, defined by Detterman and Reed (1980), is a lithologically diverse and complex assemblage of metamorphosed mafic plutonic, volcanic, and sedimentary rocks found on west side of Cook Inlet. Detterman and Hartsock (1966) mapped "metalimestone", argillite, quartzite, metatuff, greenstone, and phyllite. Detterman and Reed (1980) described unit as largely consisting of roof pendants within the Alaska-Aleutian Range batholith and believed that the Kakhonak Complex represents, in part, the metamorphic equivalent of Upper Triassic and Lower Jurassic rocks, the Kamishak and Talkeetna Formations, of the vicinity. However, quartzite and quartz-mica schist within the Kakhonak Complex have no direct equivalent within the sedimentary rocks of the vicinity, indicating other protoliths may have contributed to the complex. As Permian rocks were known from Puale Bay, about $300 \mathrm{~km}$ south of the map area, a possible Paleozoic age was not excluded by Detterman and Reed (1980). Internal contacts are typically faults, resulting in a tectonic mix of lithologies. Although most of the rocks of this complex are at greenschist facies, the rocks range from nonmetamorphosed to granulite facies

\section{IGNEOUS ROCKS}

Qv Volcanic rocks, undivided (Quaternary) - Andesite, dacite, and basalt lava flows, volcanic breccia, lahar deposits, and debris-flow deposits. Includes air-fall tuff, volcanic dome deposits, block- and ash-flow deposits, ash-flow tuffs, volcanic-rubble flows, debris flows, and hot-blast avalanche deposits. Also includes tephra-rich colluvium in vicinity of and west of Redoubt Volcano where deposits both mantle and are incorporated into deposits of Holocene glaciation (Till and others, 1993; F.H. Wilson, unpub. data). Lava flows and clasts are porphyritic, typically glassy, gray to black, and commonly vesicular. Andesite is dominant composition and probably constitutes 60 percent or more of rocks. Unit typically forms volcanic edifices. Unit mapped at Redoubt and Iliamna Volcanoes includes Holocene rocks that cap ridges and include massive lava flows, agglomerate, and lahar deposits. May include Tertiary volcanic rocks, as mapped by Magoon and others (1976). Locally subdivided into:

Qdf Debris-flow deposits (Holocene) - Volcanic debris-flow and mudflow deposits from Redoubt Volcano in Crescent River valley. Includes several small (older?) deposits in the upper valley and a 3,500-yr-old debris flow in the lower valley (F.H. Wilson, unpub. data). The older deposits are from multiple debris flows off west and southwest flanks of Redoubt Volcano. Oldest(?) deposit is derived from west flank of Redoubt. Next oldest deposit appears to be derived from presently glaciated valley draining to the southwest off Redoubt. These older deposits are of relatively limited extent, but may have dammed the North Fork, Crescent River, creating a temporary lake in the valley. Deposits of the youngest, most extensive, and probably most fluid debris flow derived from southwest flank of Redoubt Volcano. Flow was apparently derived from the only presently glacier-free valley draining south from Redoubt. This debris flow was dated at 3,500 yr B.P. (Riehle and others, 1981), young enough to 
possibly explain the lack of glaciers in the source valley, as all surrounding valleys have extensive glaciers and glacial deposits. This debris-flow deposit extends to the coast of Cook Inlet and up the main fork of the Crescent River, creating a dam that contains Crescent Lake. Also includes Holocene age mudflow deposits in the Drift River valley draining north and east from Redoubt Volcano (Till and others, 1993); some Drift River deposits are historic including 1966 and later flows

Qad Andesite and dacite domes (Pleistocene)-Medium to coarsely porphyritic hornblende andesite and dacite of composite dome complex of Double Glacier Volcano (Reed and others, 1992). Three K-Ar andesite whole-rock ages were determined on these domes; two are considered minimum ages at $627 \pm 24$ and $763 \pm 17 \mathrm{ka}$ (sample 78AR 290, table 1) and one is $887 \pm 15 \mathrm{ka}$ (sample 90AR 99, table 1) (Reed and others, 1992)

Tvu Lava flows (middle? to late? Tertiary) - A small exposure of dark-blue-gray to black, cryptocrystalline to vesicular basalt and andesite occurs on mainland northwest of Chisik Island (Detterman and Hartsock, 1966) and is one of a number of scattered exposures in their map area. As described, the flows are slightly altered and locally contain irregular veins of hematite and malachite in altered zones along shear planes. Flows unconformably overlie an exposure of the Talkeetna Formation. Detterman and Hartsock (1966) inferred the flows were of middle(?) or late(?) Tertiary age based on degree of dissection and correlation with flows in Iliamna Lake region where flows overlie Tertiary age sedimentary rocks

TKgd Granodiorite (Tertiary and (or) Cretaceous) - Medium-grained, hypidiomorphic granular, seriate granodiorite. Biotite tends to be more abundant than hornblende. Occurs in northwest corner of the Kenai quadrangle west of Lake Clark Fault and in adjacent Lake Clark quadrangle (Reed and Lanphere, 1972, 1973; Magoon and others, 1976; Detterman and others, 1976). K-Ar ages on biotite and hornblende range from $65.1 \pm 1.9$ to $70.5 \pm 2.0 \mathrm{Ma}$ (Reed and Lanphere, 1972, 1973; Magoon and others, 1976; Detterman and others, 1976)

Kqd Quartz diorite (Cretaceous) _ Locally foliated, largely medium-grained hornblende-biotite quartz diorite, but includes hornblende-pyroxene gabbro and diorite, quartz diorite, tonalite, and minor granodiorite (Magoon and others, 1976; Nelson and others, 1983; Reed and others, 1992). In northwestern part of map area, east of Lake Clark Fault, these rocks were mapped as Tertiary or Cretaceous by Magoon and others (1976). Biotite-hornblende ratio is quite variable although color index remains constant. Deuteric epidote is common. K-Ar ages on biotite and hornblende range from 67.2 \pm 1.9 to $74.4 \pm 2.2 \mathrm{Ma}$ (Reed and Lanphere, 1972, table 1 herein); shown as Cretaceous here

KJg Quartz monzodiorite (Cretaceous? and (or) Jurassic?) -Medium-gray, medium-grained, hypidiomorphic granular hornblende-biotite quartz monzodiorite; contains variable amounts of clinopyroxene; located in extreme northwestern part of Kenai quadrangle. Flow structures locally present and hornblende and plagioclase are aligned north-northeast. Two samples from outside map area yield strongly discordant K-Ar biotite and hornblende ages between 58.8 and 97.5 Ma (Nelson and others, 1983). Part of the Alaska-Aleutian Range batholith of Reed and Lanphere $(1969,1972)$

Alaska-Aleutian Range batholith (Jurassic phase)-Subdivided into:

Jtr Trondhjemite (Late Jurassic) - Medium- to coarse-grained, seriate, leucocratic trondhjemite; contains 10 percent muscovite and about 5 percent interstitial, perthitic potassium feldspar. Occurs in two bodies in Kenai quadrangle immediately west of Redoubt Volcano and in headwaters of Big River north of Double Glacier (Reed and others, 1983). Unit comprises a large body in central part of batholith in Iliamna quadrangle west of Chinitna Bay. K-Ar age on muscovite from Iliamna quadrangle was $148 \mathrm{Ma}$ (Reed and Lanphere, 1972, analytical error not reported)

Jg Quartz diorite, tonalite, and diorite (Jurassic) - Locally foliated medium-grained quartz diorite and tonalite; this is by far the dominant map unit of the Alaska-Aleutian Range batholith in map area. Hornblende is primary mafic mineral; biotite increases in proportion to quartz and potassium feldspar. Detterman and Reed (1980) reported rocks of this unit grade to diorite but did not observe it grading into quartz monzonite or granodiorite of their unit Jqm. As mapped here, unit includes Detterman and Reed's quartz monzonite unit that consists of medium-grained, pinkish-light-gray quartz monzonite and whitish-gray, mediumgrained, biotite granodiorite containing minor hornblende and accessory primary muscovite. Detterman and Reed's quartz monzonite unit is exposed only on eastern margin of batholith 
within map area. Potassium-argon ages generally range from $146 \pm 4.3$ to $183 \mathrm{Ma}$ for the batholith; a number of samples yielded younger ages that are considered suspect or reset by younger plutonism. Maximum reported age within map area is $174 \mathrm{Ma}$ (table 1). Two small exposures of gabbro and diorite are included in unit

Kdt Quartz diorite and tonalite (Late Triassic) - In Seldovia quadrangle, unit includes diorite of Point Bede and tonalite of Dogfish Bay of Bradley and others (1999), both on east side of Cook Inlet. Diorite of Point Bede of Bradley and others (1999) is fine- to medium-grained nonfoliated quartz diorite that Bradley and others (1999) assumed to be of Jurassic age based on correlation with a quartz diorite pluton in the Barren Islands, just south of Seldovia quadrangle, that yielded a K-Ar hornblende age of 191 $\pm 1.3 \mathrm{Ma}$ (Cowan and Boss, 1978, age recalculated using constants of Steiger and Jager, 1977). However, a Triassic age was recently determined on zircon from the diorite (D.C. Bradley, oral commun., 2007). Tonalite of Dogfish Bay of Bradley and others (1999) is medium-grained nonfoliated tonalite which shows chloritic alteration similar to that found in the diorite of Point Bede and hence was assigned a Jurassic age by Bradley and others (1999). We show diorite and tonalite as a single map unit of Triassic age. Bradley and others (1999) also mapped a light-gray, finegrained to aphanitic felsite body south of the tonalite of Dogfish Bay. This felsite is undated and is tentatively assigned a Triassic age due to its proximity and similar setting to the tonalite and diorite of this map unit. Bradley and others (1999) suggested the felsite could be early Tertiary in age; however, no other rocks of Tertiary age are reported in this vicinity. Kelley $(1980,1984)$ mapped an intrusive contact between the diorite and his informal Pogibshi formation (Jp); however, both the newly determined Triassic zircon date from the diorite and Jurassic fossils from the Pogibshi indicate that there is some error in interpretation of available data. Possible scenarios include an incorrectly mapped contact, a wider age range for the Pogibshi formation of Kelley (1980), or inheritance in the zircon

\section{ROCK UNITS WITHIN THE BORDER RANGES FAULT SYSTEM}

\section{METAMORPHIC ROCKS}

Jsch Seldovia metamorphic complex (Early Jurassic)-Marble, quartzite, garnet-mica schist, and glaucophane-bearing amphibolite whose protoliths were interpreted by Bradley and others, (1999) to consist of limestone, chert, argillite, and greenstone. Unit occurs as narrow fault slices within the Border Ranges fault zone south of Seldovia and has been correlated with Raspberry Schist of Roeske and others (1989) to the southwest and to Schist of Liberty Creek and Schist of Iceberg Lake of Winkler and others (1981) to the northeast. Although primarily greenschist facies, these units preserve mineral assemblages that represent blueschist facies metamorphism. Carden and others (1977) reported a series of $10 \mathrm{~K}$-Ar ages on micas (including chlorite) and amphiboles from this unit ranging from $158.3 \pm 8.3$ to 197.1 $\pm 11.0 \mathrm{Ma}$, and Bradley and Karl (2000) reported $40 \mathrm{Ar} /{ }^{39} \mathrm{Ar}$ plateau ages on mica of 191.1 \pm 0.3 and 191.7 $\pm 0.3 \mathrm{Ma}$ and on hornblende of 191.9 $\pm 0.6 \mathrm{Ma}$. Dating of the blueschist facies metamorphism of this metamorphic complex appears to support a pattern of decreasing age from west to east, as originally suggested by Sisson and Onstott (1986)

\section{ROCK UNITS EAST OR SOUTH OF THE BORDER RANGES FAULT SYSTEM}

\section{BEDDED ROCKS}

Qty Yakataga Formation (Pleistocene to Miocene) - "Consists of diverse marine and glaciomarine clastic rocks more than 1,670-m-thick on Kayak and Wingham Island and at least an additional 1,200-m-thick on Middleton Island (Plafker and Addicott, 1976). Much of the continental shelf between Middleton Island and Kayak Island also is underlain by the Yakataga [Formation] (Plafker and others, 1975a). Interbedded gray to dark-gray and greenish-gray siltstone, mudstone, and sandstone predominate in lower third of formation. Till-like diamictite is interbedded with siltstone and sandstone in all but the lowest part of the formation and is the dominant rock type in the upper part of the formation, particularly on Middleton Island. Conglomerate is a minor lithology throughout the formation and scattered clasts - presumably dropstones - are present in all lithologies. Sandstone and conglomerate combined constitute about 10 percent of the section on Kayak Island and about 12 percent on Middleton Island" (Winkler and Plafker, 1993). In most exposures the Yakataga Formation is conformable and gradational to the underlying Poul Creek Formation but in some 
areas there is an angular unconformity of up to 15 degrees (Plafker and Addicott, 1976). Age control derived from abundant mollusks and foraminifers, although most are identical to living species (Winkler and Plafker, 1981; Plafker and Addicott, 1976). Foraminifera are typical of the lower or middle Miocene Saucesian or Relizian Stages of Washington (Rau and others, 1977). Paleomagnetic and biostratigraphic dating indicate upper part of formation on Middleton Island was deposited during Matuyama reversed polarity chron (Plafker and Addicott, 1976)

Redwood Formation (Pliocene to Oligocene?) - Marine mudstone, siltstone, sandstone, and conglomerate (Winkler and Plafker, 1981). "Lower unnamed sandstone member consists of about two-thirds thick-bedded sandstone and one-third silty sandstone and siltstone. Upper Puffy Member is more diverse and consists of about 50 percent siltstone, mudstone, and claystone, 30 percent conglomeratic mudstone and conglomerate, and 20 percent sandstone. Characteristic conglomeratic beds show complete gradation from coarse-grained, clastsupported conglomerate to matrix-supported conglomeratic mudstone and sandstone where coarse-grained clasts are suspended in the matrix. Siltstone, mudstone, and claystone are similar in appearance to parts of the underlying Poul Creek Formation but contain few or no concretions, no glauconitic or volcanic beds, and are sandier and more resistant to erosion" (Winkler and Plafker, 1993). "The fauna and lithology of the Redwood Formation indicate deposition below wave base in cold water at depth from neritic to probably bathyal. The well rounded character of clasts in the conglomerate indicates that the coarser clastic material was thoroughly abraded before being resedimented in the marine environment. The sparse and poorly preserved molluscan fauna from the formation suggests a correlation with the upper Galavinian ("Lincoln") and Matlockian ("Blakeley") Stages of the Pacific Northwest, or a range in age from late Eocene through Oligocene (Addicott and others, 1978). Foraminiferal control is extremely sparse, but suggests that the upper part of the formation may be as young as late Miocene (Rau and others, 1977); however, the USGS has accepted an age of late Oligocene(?) through early Pliocene for the unit (Plafker, 1987). Thus, the Redwood Formation in the Don Miller Hills apparently correlates with the upper part of the Poul Creek Formation and the lower part of the Yakataga Formation exposed on Kayak and Wingham Islands" (Winkler and Plafker, 1981)

Poul Creek Formation (lower Miocene to late Eocene) - Originally named Katalla Formation (Martin, 1905) whose definition was revised by Miller (1975); however, unit name was abandoned and Poul Creek Formation name was extended to map area from east by Nelson and others (1985). Unit consists of "Shale, and minor sandstone that is, in part, glauconitic, rich in organic material, and intercalated with intrabasinal, water-laid alkalic basaltic tuff, breccia, and pillow lava. Unit exposed intermittently along coastal belt in Gulf of Alaska region from Kayak Island through Ragged Mountain eastward to Icy Bay in the adjoining Bering Glacier quadrangle. Unit also penetrated in wells drilled along the coast and offshore in adjacent outer continental shelf. In Chugach National Forest area of Nelson and others (1985), unit conformably overlies the Tokun Formation; in Don Miller Hills, unit conformably underlies the Redwood Formation, but on Kayak Island unit is separated from the overlying Yakataga Formation by an apparent disconformity" (Winkler and Plafker, 1993). Although reported to conformably underlie Redwood Formation and overlie Tokun Formation, defined ages for the three units suggest the contacts may be locally time-transgressive. Subdivided into sedimentary rocks and volcanic rocks members, described below:

Tps Sedimentary rocks - "Concretionary, pyritic, glauconitic, reddish-weathering, dark-gray to greenish-gray siltstone, claystone, and sandstone; subordinate dark-brown, laminated shale that is rich in organic material, silty shale, and gray calcareous sandstone; locally includes thin interbeds of basaltic tuff" (Winkler and Plafker, 1993). Thickness is approximately 1,600 m (Miller, 1975). "Deposited in cool neritic to bathyal marine environment, mostly below wave base. Occurrence of shales as much as 244-m-thick with high organic carbon contents (to 7.57 percent), extractable petroleum ( 0.8 gallons per ton), abundant glauconite, and common pyrite are suggestive of deposition in part under conditions of restricted bottom circulation. Intercalated basaltic fragmental rocks and less common pillow basalt (map unit Tpv) indicate episodic submarine mafic volcanism in the basin (Plafker, 1974). Mollusks indicate a range in age from late Eocene (Galvinan or "Keasey") through much of the Oligocene (Matlockian or "Blakeley") (Addicott and others, 1978). In general, foraminifera from the same localities indicate slightly younger ages, ranging from late Eocene through early 
Miocene (Refugian, Zemorrian, and Saucesian Stages) (Rau and others, 1977)" (Winkler and Plafker, 1981)

Tpv Volcanic rocks - "Basaltic pyroclastic and flow rocks, including minor pillowed lava flows; locally interbedded with marine sedimentary rocks, including tuffaceous or glauconitic strata, probably related genetically to mafic dikes, sills, and plugs unit (Tm)" (Winkler and Plafker, 1993). Winkler and Plafker (1981) reported a K-Ar whole rock date of $31.2 \pm 1.3 \mathrm{Ma}$ on a sample from the mafic dike unit (Tm) intruding unit Tps on southeast side of Kayak Island, providing a minimum age for unit

Tokun Formation (Eocene) - “Consists predominantly of concretionary siltstone and lesser, variable amount of interbedded sandstone, chiefly in lower part of formation. Thick sandstone beds exposed near Point Hey and on Kayak and Wingham Islands presumably correlate with lower part of formation to the north but were closer to the sediment source. Siltstone generally is medium to dark gray and nearly massive; locally, thin beds and lenses of lighter gray, brown-weathering calcareous siltstone and silty limestone are found within darker siltstone. Spheroidal calcareous concretions as much as $1 \mathrm{~m}$ in maximum dimension are distributed randomly or along bedding surfaces in siltstone. Near Bering Lake, thin beds of glauconitic sandstone are found near top of formation. Interbedded sandstone in Tokun, which generally is lighter gray than the siltstone, is micaceous, feldspathic, and brown weathering. Isolated, intertidal outcrops of coarse- to fine-grained, brown-weathering feldspathic sandstone on Wessels Reef, which are exposed only at low tide, may correlate with the Tokun Formation" (Winkler and Plafker, 1993). "Lithology and megafauna indicate general deposition under quiet bottom conditions seaward of the surf zone in tropical to warm temperature water (Miller, 1975)" (Winkler and Plafker, 1981). Gradational contact with underlying mostly nonmarine Kulthieth Formation and has gradational to abrupt contact with overlying Poul Creek Formation (Winkler and Plafker, 1981). Represents a transgressive marine sequence approximately 1,070 m thick (Winkler and Plafker, 1981). Fossil crabs are abundant, especially in upper part of formation and occur intact in concretions (Winkler and Plafker, 1981). Sparse mollusks indicate middle and upper Eocene "Tejon" and "Keasey" Stages of the Pacific Coast standard section (Addicott and others, 1978)

Tkt Kulthieth Formation (Eocene) - "Includes at least 1,500 m of interbedded, massive to thinbedded, coal bearing arkosic sandstone, dark-gray to black carbonaceous siltstone and shale, and minor coal. Sandstone to shale ratios in measured sections of the Kulthieth Formation (Martin, 1908) average about 1:1. Sandstone varies from massive intervals as much as 150 -m-thick to thin-bedded and shaly intervals. Bituminous to semi-anthracite coal in beds as much as 3-m-thick is conspicuous, but minor part of sequence. Commonly intensely deformed into imbricated stacks of fault-bounded chevron folds displaying shearing and structural thinning and thickening of coal beds" (Winkler and Plafker, 1993). "Mostly nonmarine, with minor tongues of transitional marine strata lithologically similar to the underlying Stillwater Formation (Tsu [in their report, Tsw herein]) and overlying Tokun Formation (Tt). Represents major progradational cycle into an otherwise marine lower Tertiary sequence" (Winkler and Plafker, 1981). Age control derived from widespread fossil plant collections and single mollusk collection near top of section (Winkler and Plafker, 1981). Mollusk collection indicates late Eocene (Tejon) age, whereas fossil plant collections indicate wider range from lower Ravenian (late middle Eocene) to lower Kummerian (early Oligocene) (Winkler and Plafker, 1981; Wolfe, 1977); however, the accepted age is Eocene

Tsw Stillwater Formation (Eocene) - "Primarily consists of dense hard dark-gray siltstone. Where siltstone is carbonaceous, it has a coal-like appearance; where it is calcareous, it may be variegated from reddish brown to pale green and usually contains foraminifers" (Winkler and Plafker, 1993). Lithology and microfauna of lower section indicate marine deposition in neritic to upper bathyal depths (Tysdal and others, 1976; Winkler and Plafker, 1981); in "**** exposures north of the Bering River, which may constitute a higher part of the formation, ***" lithology and megafauna indicate regressive shallow marine deposition (Winkler and Plafker, 1981). Grades upward into nonmarine rocks of overlying Kulthieth Formation (Miller, 1951; MacNeil and others, 1961). "Dominantly marine strata of the Stillwater Formation in the map area may be coeval with the nonmarine lower part of the Kulthieth Formation $65 \mathrm{~km}$ to the east in the Bering Glacier quadrangle (Miller, 1961; MacNeil and others, 1961)" (Winkler and Plafker, 1981). "The Stillwater Formation is complexly deformed and is characterized by tight folds and shearing in incompetent strata; 
hence its thickness can be estimated only crudely to be at least 1,500 m (Plafker, 1971)" as reported in Winkler and Plafker (1981). Age control derived from poorly constrained ages of forams and mollusks. "According to W.W. Rau, the foraminifera indicate a range from possibly the Paleocene and early Eocene Bulitian Stage to the middle Eocene Ulatisian Stage. The mollusks indicate a younger age, late middle or early late Eocene (F.S. MacNeil in Wolfe, 1977)" (Winkler and Plafker, 1981)

Orca Group (lower middle Eocene to late Paleocene) - Originally named by Schrader (1900), unit consists of widespread complexly deformed flyschoid sedimentary and intercalated mafic volcanic and intrusive rocks (Winkler, 1976; Tysdal and Case, 1979; Nelson and others, 1985). Thick monotonous sequence of turbiditic sedimentary rocks including thin- to thick-bedded sandstone, siltstone, mudstone, and local conglomerate represent middle (and possibly inner) submarine fan deposits (Winkler and Tysdal, 1977; Dumoulin, 1987). Mafic rocks include ultramafic intrusive rocks, gabbro, sheeted basalt dikes, and pillow basalt (Winkler, 1976; Winkler and Tysdal, 1977; Nelson and others, 1985). The igneous rocks, while remaining part of the defined Orca Group, are described here under the heading of "Ophiolitic rocks of Prince William Sound" in the igneous rocks section of the Description of Map Units. Orca Group as a whole variably metamorphosed from laumontite (prehnitepumpellyite) to lower-greenschist facies; hornfels is developed near plutons (Nelson and others, 1985). "The lowest grade rocks form a northeast-southwest-trending belt that includes Montague and Hinchinbrook Islands; metamorphic grade increases to the north and the northwest" (Dumoulin, 1987). Northeastern contact between the Orca and Valdez Groups generally accepted to lie along Jack Bay, Gravina, and Bagley Faults in Cordova quadrangle (Bol and Roeske, 1993; Winkler and Plafker, 1993; Dumoulin, 1987). Western contact with the Valdez Group is less well established due to poor age control and similarities between the two units (Dumoulin, 1987; Bol and Gibbons, 1992). Western contact is shown here to lie along the Contact Fault, but alternatively the contact may instead lie along Johnstone Bay or Bainbridge Bay Fault of Helwig and Emmet (1981) as suggested by Dumoulin (1987), or elsewhere. Dumoulin (1987), on the basis of sandstone petrography, suggested "**** that the Valdez and Orca Groups form a single flysch sequence derived from one progressively unroofing source ***." In the Cordova quadrangle, the Orca Group is bounded on southeast along the Wingham, Ragged Mountain, and Chugach Faults by rocks of Stillwater (Tsw) and Tokun (Tt) Formations (Winkler and Plafker, 1981, 1993). Unit subdivided into:

Tos Sedimentary rocks, undivided-Thin- to thick-bedded graywacke sandstone, siltstone, mudstone, slate, and locally, minor conglomerate. Abundant sedimentary structures, such as graded bedding, crossbedding, and ripple marks, along with flute, groove, and load casts, indicate deposition from turbidity currents (Tysdal and Case, 1979; Nelson and others, 1985). Graywacke sandstone is more abundant than finer grained rocks (Tysdal and Case, 1979). Bioturbated limestone lenses and concretions are found locally, and along with conglomerate, are characteristic of sedimentary rocks belonging to the Orca Group (Moffat, 1954; Tysdal and Case, 1979; Nelson and others, 1985). Lenticular matrix-supported conglomerate and pebbly mudstone and sandstone lenses are widespread, and contain clasts of intrabasinal and extrabasinal sedimentary rocks, felsic igneous rocks, and quartz (Winkler and Plafker, 1993). Thin-section petrography indicates that most of the sandstone is feldspathic to feldspatholithic (Nelson and others, 1985) and contains abundant monocrystalline quartz, indicating a plutonic provenance (Dumoulin, 1987, 1988). Winkler and Plafker (1993) reported unit is metamorphosed to zeolite or prehnite-pumpellyite facies in Cordova and Middleton Island quadrangles; Nelson and others (1985) reported alteration ranges from diagenetic recrystallization of the matrix to low greenschist facies metamorphism. In Seward and Blying Sound quadrangles, unit also includes rocks mapped as siltstone by Tysdal and Case (1979); their siltstone unit is locally tightly folded and metamorphosed to slate; medium-gray and green lenses of micritic limestone as much as $2 \mathrm{~m}$ thick are present locally. At several places in the islands south of Knight Island Passage, Tysdal and Case (1979) describe locally folded and contorted sequences of siltstone and isolated greenstone blocks mixed in with sandstone and siltstone within otherwise uniformly layered sections. Tysdal and Case (1979) thought these sequences were olistostromes. Tysdal and Case (1979) reported the same sedimentary rock types are included in their sedimentary rock-greenstone map units containing basalt sills (Togs) and pillow basalt (Tops) which are herein assigned to units Tosv and Tov, respectively. Fossils reported by Nelson and others (1985) include 
Alnus (Alder) pollen; foraminifers Globogerina sp., G. senni, Globogerina sp. (hispid), and Globorotalia sp.; and echinoids Holaster sp., ?Hypsopygaster sp., and Nucleopygus

Toc Conglomerate - "Ranges from matrix-supported pebbly mudstone and sandstone to massive clast-supported pebble, cobble, and boulder conglomerate" (Nelson and others, 1985). Generally well rounded clasts consist primarily of extrabasinal felsic volcanic and igneous rocks (felsic porphyry and tuff, granitic rocks, and white quartz) and intrabasinal sedimentary and mafic rocks (greenstone, sandstone, siltstone argillite, and limestone) (Nelson and others, 1985; Winkler and Plafker, 1993; Winkler and Tysdal, 1977; Moffit, 1954). Usually occurs as lenses 90 to $210 \mathrm{~m}$ thick within flyschoid rocks; though the thickest lens, located in Miners Bay (approximately $7 \mathrm{~km}$ north of the map area in Unakwik Inlet), measured $900 \mathrm{~m}$ thick (Nelson and others, 1985). Matrix-supported conglomerate and pebbly mudstone may have been formed by submarine landslides on unstable slopes, whereas inversely and normally graded clast-supported conglomerate beds are channel fill deposits in feeder and distributary channels (Winkler and Tysdal, 1977). Fossils reported by Addicott and Plafker (1971, cited in Nelson and others, 1985) include a crab, Branchioplax washingtoniana, and a pelecypod, Acila decisa, that indicate Paleocene(?) to late Eocene age

Valdez Group (Upper Cretaceous) - A widespread unit of the coastal region of south central Alaska. Consists primarily of complexly deformed metasedimentary graywacke, siltstone, and shale generally considered to be deposits of turbidity currents in an oceanic trench (Tysdal and Case, 1979; Nelson and others, 1985; Winkler and Plafker, 1981, 1993). Includes a variety of interbedded, tholeiitic meta-volcanic and meta-intrusive rocks and locally a mélange facies. Valdez Group ranges in metamorphic grade from laumontite- to mid-greenschist-facies and locally reaches amphibolite facies east of Copper River (Nelson and others, 1985; Winkler and Plafker, 1981). Valdez Group is correlative with Kodiak Formation (Capps, 1937; Wilson and others, 2005), Shumagin Formation (Wilson and others, 1999), and partially with Sitka Graywacke (Gehrels and Berg, 1992), which together make up the Chugach terrane that extends for more than $1,700 \mathrm{~km}$ along southern coast of Alaska. Subdivided into:

Kvs Metasedimentary rocks, undivided-Dark-gray, thin- to thick-bedded, laumontite to midgreenschist facies metamorphosed, moderately to poorly sorted sandstone, siltstone, and mudstone flysch; fine- to coarse-grained sandstone mainly composed of plagioclase, quartz, and igneous rock fragments (Tysdal and Case, 1979; Dumoulin, 1987). Unit is thick sequence of rhythmically alternating, multiply deformed, metamorphosed sandstonesiltstone turbidites; beds generally range from a few centimeters to a few meters thick to locally, massive beds as much as tens of meters thick (Winkler and Plafker, 1981; Nelson and others, 1985; Winkler and Plafker, 1993; Bradley and others, 1999). Point count analysis by Dumoulin (1987) showed Valdez Group sandstone contains between 6 to 30 percent quartz, 23 to 45 percent feldspar, and 28 to 68 percent lithic fragments; lithic fragments are dominantly volcanic rocks. Proportion of lithic fragments decreases from west to east, as feldspar and quartz increases (Nelson and others, 1985). Conglomeratic sandstone containing clasts of quartzite, intermediate and felsic volcanic rocks, and rare sandstone, limestone, and granitic rocks is uncommon but widely distributed, occurring at base of some sandstone beds (Bradley and others, 1999; Bradley and Miller, 2006). In some places, primary sedimentary structures such as graded bedding, current-ripple cross-lamination, convolute bedding, and sole markings are preserved (Nelson and others, 1985; Winkler and Plafker, 1993). Inoceramus kusiroensis, Inoceramus ulrichi, and Inoceramus concentrica of Maastrichtian or Late Cretaceous age have been reported (Tysdal and Plafker, 1978; Tysdal and Case, 1979; Nelson and others, 1985; Bradley and others, 1999). A K-Ar date on biotite semischist of $51.5 \pm 1.5 \mathrm{Ma}$ was reported by Nelson and others (1985). D.C. Bradley (USGS, oral commun., 2007) reported 70 Ma detrital zircons from unit near Anchorage

Kvvs Interbedded metavolcanic and metasedimentary rocks-Approximately equal portions of interbedded metavolcanic and metasedimentary rocks (Winkler and Plafker, 1981; Nelson and others, 1985; Winkler and Plafker, 1993). Metavolcanic rocks include semischistose volcanic breccia, tuff, tuffaceous sediment, and minor pillow basalt; metasedimentary rocks include slate and phyllite, although metamorphosed sandstone, siltstone, and chert are interbedded in many places (Winkler and Plafker, 1981; Nelson and others, 1985; Winkler and Plafker, 1993). Unit crops out in two locations: north central Cordova quadrangle, and east side of Resurrection Peninsula in Seward quadrangle. Winkler and Plafker (1993) report unit 
tends to be "variably metamorphosed regionally from zeolite to lower greenschist facies, although near Cordova, Woodworth, and Schwan Glaciers rocks are transitional to amphibolite facies"

Kvv Metavolcanic rocks, undivided-Tholeiitic metabasalt, massive greenstone, and basaltic metatuff, including local pillow lava, pillow breccia, and gabbroic dikes and sills (Winkler and Plafker, 1993) in Cordova quadrangle. Metabasalt forms rugged, nearly massive outcrops, whereas semischistose metatuff forms more subdued outcrops (Winkler and Plafker, 1993)

Kvt Aquagene tuff - Green to dark-gray, fine-grained, and finely laminated tuff contains plagioclase phenocrysts; metamorphosed to chlorite and biotite zones of greenschist facies; chlorite, epidote, and, locally, actinolite are abundant; remnants of glossy shards are present (Tysdal and others, 1977; Tysdal and Case, 1979). Whole rock age for metatuff on Fox Island of $54.4 \pm 2.7$ Ma was interpreted by Miller (1984) as possibly reset during a thermal event; alternatively, metatuff on Fox Island (formerly Renard) is closely associated with ophiolitic rocks of Resurrection Peninsula, now considered Eocene age. Whole-rock age determination on metamorphosed tuff is considered suspect

Kvgs Schist-Schistose metamorphic rocks found in two general modes of occurrence. In Cordova quadrangle, Winkler and Plafker (1993) describe a "chiefly homogenous pelitic schist and minor amphibolite; [unit which] also includes spotted biotite-plagioclase-quartz ( \pm muscovite) schist containing porphyroblasts of cordierite, andalusite, garnet, and staurolite in several places. Common banding probably represents original layering inherited from protoliths; transitional into gneissose rocks to the east and into greenschist-facies rocks of the metasedimentary rocks unit (Kvs) to the west." In contrast, in Seward and Blying Sound quadrangles, Tysdal and Case (1979) describe a schist unit as "interbedded siltstone, graywacke, and less abundant tuff, tuffaceous sandstone, and basalt (pillow basalt?) ***." These rocks are primarily localized on west side of Placer River Fault and “*** * metamorphosed chiefly to biotite zone of greenschist facies, but locally to chlorite zone; typical metamorphic-mineral assemblages of biotite zone are biotite-muscovite-chlorite-quartz-epidote-calcite-albite ***" (Tysdal and Case, 1979). Nelson and others (1985) did not map the schistose rocks mapped by Tysdal and Case (1979) as a distinct unit because they reported the rocks to be only semi-schistose and interlayered with rocks that have no penetrative deformation; Nelson and others (1985) reported that rocks such as these were common throughout the Valdez Group, especially near faults and in areas of finer grained sedimentary protolith. However, we have retained the belt of schistose rocks along the Placer River Fault by Tysdal and Case (1979), which they reported as being conspicuously schistose and the only extensive area of schistose rocks in their map area. Nelson and others (1985) reported other areas of schistose rocks are common in the Valdez Group, yet none are distinguished on maps to date except by Tysdal and Case (1979) for areas on Fox [Renard] Island and Resurrection Peninsula; on Resurrection Peninsula, the unit occurrence is included in unit Kvs here, following the mapping of Bradley and Miller (2006)

Kvgg Gneiss - "Muscovite-biotite-quartz-plagioclase ( \pm sillimanite and garnet) schist, banded gneiss, and migmatitic gneiss; potassium-feldspar-bearing segregations in migmatite; many local intrusive stringers, dikes, and sills of granodiorite and granite; transitional into schistose rocks to the north, south, and west" (Winkler and Plafker, 1993). Nelson and others (1985) describe unit as a paragneiss of "predominantly metasedimentary rocks with well-developed gneissic foliation consisting of alternating quartz and feldspar-rich layers with biotite-rich layers. $* * *$ Locally some layers in the paragneiss contain 1-in.-long [2.5 $\mathrm{cm}$ ] porphyroblasts of andalusite." Unit contains as much as 10 percent cream-colored or light-gray, coarse-grained orthogneiss that locally grades into normal textured granitic rocks containing abundant inclusions of country rock (Nelson and others, 1985). Metamorphic grade ranges from middle to upper amphibolite facies (T.L. Pavlis and V.B. Sisson, written commun., 2002). Hudson and others (1979) reported hornblende and biotite ages of $52.8 \pm 2$ $\mathrm{Ma}$ and 47.9 $\pm 2 \mathrm{Ma}$ respectively on amphibolite and schist in Bering Glacier quadrangle, east of map area. Unit is gneissic equivalent of Valdez Group found along Wernicke Glacier

Kvm Mélange of Iceworm Peak of Kusky and others (1997) —Tectonic mélange of blocks of graywacke in a phacoidally cleaved matrix of slate; Valdez Group protolith for both matrix and blocks (Bradley and others, 1999; Bradley and Wilson, 2000). Mapped only in Seldovia and Kenai quadrangles but may be more extensive along McHugh Complex and Valdez 
Group contact (Kusky and others, 1997). Intruded by Paleocene dikes (Kusky and others, 1997) not shown here

$\mathrm{KCm}$ McHugh Complex, undivided (Cretaceous to Carboniferous, Mississippian) - "Mélange of siltstone, sandstone, mud-chip sandstone, conglomeratic sandstone, tuff, and less abundant gabbro, serpentinite, bedded chert, and pillow basalt; fine-grained sedimentary strata commonly streaked out; sedimentary and igneous rocks are broken and discontinuous; metamorphic minerals include muscovite, epidote, calcite, chlorite, albite, and veinlets of prehnite" (Tysdal and Case, 1979). Paraphrasing Clark (1981), McHugh Complex is a heterogeneous, chaotic assemblage that includes metamorphosed clastic and volcanic rocks of diverse ages. Clastic rocks, which are the most abundant, comprise thick, fault-bounded sequences of weakly metamorphosed graywacke, arkose, siltstone, and conglomeratic sandstone. Bedding is rarely seen and commonly discontinuous. Volcanic rocks in the McHugh Complex, also in fault-bounded sequences, are greenstone, mostly of basaltic composition, and are associated with radiolarian metachert, metasiltstone, and argillite. Clark (1981) thought the volcanic rocks represent oceanic crust and that the clastic sedimentary rocks were deposited in an oceanic trench. Sedimentary rocks of the mélange matrix yield Early Cretaceous (Valanginian) fossils, whereas protolith ages on blocks in the mélange yield radiolarians of Cretaceous (Albian-Aptian), Jurassic, and Triassic age (Bradley and others, 1999; Winkler and others, 1981), Permian conodonts and fusilinids (Bradley and others, 1999), and Mississippian to Pennsylvanian conodonts (Nelson and others, 1986). D.C. Bradley (USGS, oral commun., 2007) reports $\sim 90$ Ma detrital zircons from metasandstone within the McHugh Complex collected along Turnagain Arm in Anchorage quadrangle to the north of map area. Bradley and others (1999) locally subdivided the McHugh Complex into distinct lithologic packages:

KJms McHugh Complex, graywacke and conglomerate (Lower Cretaceous to Lower Jurassic, Pliensbachian) - Consists of fault-bounded blocks of massive conglomerate and graywacke that range up to several kilometers in structural thickness (Bradley and others, 1999). Bradley and others (1999) reported that deformation has generally obliterated primary sedimentary features; they interpreted the conglomerate and massive graywacke to be of turbiditic origin and locally noted the presence of thin- and medium-bedded turbiditic graywacke. Graywacke is matrix-supported, poorly sorted, and has clasts consisting primarily of chert and volcanic rock fragments (Bradley and others, 1999). Bradley and others (1999) reported Pliensbachian radiolaria in conformably underlying ribbon chert at one locality and considered unit ranges in age regionally from Lower Jurassic, Pliensbachian, to as young as Lower Cretaceous

K Kmc McHugh Complex, basalt and chert (Lower Cretaceous, Albian, to Middle Triassic, Ladinian) - "Pillow and massive basalt, depositionally overlain by complexly folded and faulted radiolarian chert" (Bradley and others, 1999). Bradley and others (1999, citing a C.D. Blome, USGS written commun. of 1994) reported radiolaria in bedded chert range in age from Middle Triassic, Ladinian, to Lower Cretaceous, Albian

Mzg Gabbro (Mesozoic) - Dark-green, medium- to coarse-grained gabbro and minor leucogabbro and plagiogranite (Bradley and others, 1999). Fault-bounded bodies in McHugh Complex; following Bradley and others (1999), only the larger bodies are shown on the map. Associated with McHugh Complex basalt and chert unit (Kkmc), which Bradley and others (1999) suggested may indicate a genetic relation and therefore they thought may indicate Triassic to mid-Cretaceous age. However, they assigned an undifferentiated Mesozoic age to the unit. Bradley and Karl (2000) reported a concordant U-Pb zircon age of $227.7 \pm 0.6 \mathrm{Ma}$

$\mathrm{Mzu} \quad$ Ultramafic plutonic rocks (Mesozoic) - Predominantly layered, variably serpentinized dunite containing rare to locally abundant layers of chromite and pyroxenite and fault slices of garnet pyroxenite and serpentinite (Bradley and others, 1999). Bradley and others (1999) reported at least 7 fault-bounded bodies, all associated with McHugh Complex. Most bodies are bounded by low-angle thrust faults. This was originally suggested for the Red Mountain body, but as discussed in Bradley and others (1999), the Red Mountain body is not a klippe as interpreted by Magoon and others (1976) but rather is bounded by late-stage, sub-vertical faults. However, Bradley and others (1999) did suggest a thrust may bound the Red Mountain body at depth and also inferred that the gabbro $(\mathrm{Mzg})$ and ultramafic rocks, while not spatially associated are comagmatic and therefore, by extension, may be Triassic to midCretaceous age; nonetheless, they are assigned a Mesozoic age 


\section{IGNEOUS ROCKS}

Tdc Dacite of Cape Saint Elias (Pliocene or Miocene) - Described by Winkler and Plafker (1993) as follows: "Prominent very pale gray dacite plug complex that forms Cape Saint Elias and Pinnacle Rock at the southwestern end of Kayak Island (Plafker, 1974). Dacite is very dense and hard and is conspicuously jointed. Unit has a microgranitic and porphyritic texture and consists of about 35 percent plagioclase, 35 percent quartz, 25 percent orthoclase, and 5 percent relict brown hornblende and biotite. Unit has sharp, nearly vertical contacts with adjacent dark-gray argillaceous rocks of the Yakataga and Poul Creek Formations, which are metamorphosed to dark hornfels for at least $100 \mathrm{~m}$ around the intrusion. Intrudes lower part of Yakataga Formation (unit QTy) and, therefore, must be at least as young as late Miocene and more likely Pliocene because unit was emplaced after enclosing strata were deformed." A whole-rock K-Ar age of $6.2 \pm 0.3 \mathrm{Ma}$ (table 1, herein) was reported by Nelson and others (1985)

Tm Mafic plugs (Oligocene?) - Strongly altered dikes, sills, and plugs of diabase, alkalic basalt, olivine basalt, and lamprophyre, mostly on or near Kayak Island. Winkler and Plafker (1993) suggested these hypabyssal rocks were probably genetically related to extrusive volcanic rocks in the Poul Creek Formation (Tpv). Winkler and Plafker (1981) described these rocks as coarse grained and diabasic in the plugs west of the Nichawak Hills and fine grained and glassy elsewhere. Immediately west of the Nichawak Hills, two plugs are diabasic, containing 45 percent euhedral plagioclase intergrown with 30 percent anhedral augite and enstatite, 5 percent opaque minerals, and 20 percent secondary chlorite. East of Ragged Mountain, an isolated plug is nepheline syenite. Lithologic associations and crosscutting relations suggest Oligocene age; nowhere does unit intrude rocks younger than the upper part of the Poul Creek Formation (Winkler and Plafker, 1981). K-Ar whole rock date of a mafic dike on Kayak Island was 31.2 $\pm 1.3 \mathrm{Ma}$ (Winkler and Plafker, 1981)

Tg Granitic rocks (Oligocene? and latest Eocene)—Plutons in Seward quadrangle are dominantly light-gray, medium- to coarse-grained biotite \pm hornblende granodiorite and granite stocks; larger stocks commonly grade inward from marginal zones containing more biotite (and locally hornblende) to more leucocratic zones; large areas of intrusions are porphyritic and contain orthoclase phenocrysts in a medium-grained groundmass; plagioclase composition ranges from oligoclase to andesine, and biotite constitutes between 5 and 15 percent (Tysdal and Case, 1979). Also includes Cedar Bay granite of Tysdal and Case (1979), a light-gray and pink, medium- and coarse-grained muscovite ( \pm biotite) granite; plagioclase composition ranges from oligoclase to andesine, and biotite is commonly less than 1 percent. Hypidiomorphic-granular texture is most common, but some varieties are equigranular or porphyritic. Biotite is the most abundant mafic mineral and is sometimes accompanied by hornblende; towards the pluton margins, hornblende commonly is predominant (Nelson and others, 1985). K-Ar dates on biotite and hornblende range from $34.2 \pm 1.7$ to $37.1 \pm 1$ Ma (Tysdal and Case, 1979; Nelson and others, 1985; ages recalculated using constants of Steiger and Jager, 1977). ${ }^{40} \mathrm{Ar} / 39 \mathrm{Ar}$ ages were $29.2 \pm 0.1$ and $31.7 \pm 0.1$ on potassium feldspar; however these dates are inherently suspect because potassium feldspar is not generally considered suitable for dating emplacement of plutonic rocks

Tgd Gabbro and diorite (Oligocene and older) - Dominantly dark-gray, medium- to coarsegrained gabbro and subordinate diorite, both having finer grained borders of quartz gabbro and quartz diorite (Tysdal and Case, 1979; Nelson and others, 1985). Gabbro generally composed of subequal amounts of labradorite and clinopyroxene; locally contains olivine on Esther Island; pyroxene largely altered to hornblende north of Paddy Bay (Tysdal and Case, 1979). Mostly subophitic texture; however, some hypidiomorphic to allotriomorphic granular and a few are porphyritic (Nelson and others, 1985). Unit considered early mafic phase associated with granitic plutons of unit Tg. Tysdal and Case (1979) originally assigned biotite K-Ar date of 37.6 $\pm 1.0 \mathrm{Ma}$ (age recalculated using constants of Steiger and Jager, 1977) to Granite of Passage Canal; Nelson and others (1985) assigned the sample locality to this map unit although the reported rock type for the date was granodiorite. Grant and Higgins (1910) and Tysdal and Case (1979) suggested, and Nelson and others (1985) supported, a genetic and chronological relation of these mafic rocks to the granitic rocks unit $(\mathrm{Tg})$

Tgg Granite and granodiorite (Eocene) - Generally medium-grained and medium- to coarsegrained hypidiomorphic-granular biotite granite having border phases of biotite-hornblende 
granite, granodiorite, and tonalite (Nelson and others, 1985) in Cordova quadrangle.

Also includes uncommon dacite (George Plafker, written commun., 1985). Mafic mineral content and color index varies with composition; color index of the granite ranges from 5 to 10 , granodiorite ranges from 10 to 20 , and tonalite ranges from 15 to 35 . In Cordova quadrangle, plutons also include biotite-muscovite \pm garnet tonalite and trondhjemite that include strongly foliated and lineated plutons, weakly foliated, syn-deformation plutons, and nonfoliated, post-deformation plutons (T.L. Pavlis and V.B. Sisson, written commun., 2002). K-Ar and ${ }^{40} \mathrm{Ar} /{ }^{39} \mathrm{Ar}$ ages range from $47.23 \mathrm{Ma}$ on dacite to $53.5 \pm 1.6 \mathrm{Ma}$ on hornblende from a sample reported only as granitic rock; a U-Pb monazite age on a sill located near Van Cleve glacier was about $54 \mathrm{Ma}$ (Poole, 1996). U-Pb age determinations on zircon from sill were unsuccessful due to inheritance and lead loss (J.N. Aleinikoff, USGS, written commun., 2007). Also included in unit is a small pluton in northern part of Seward quadrangle on west side of Port Wells. Surrounded by plutons assigned to unit Tg, this small pluton is assigned to map unit Tgg on the basis of reported age ( $56 \pm 1 \mathrm{Ma}$, listed in table 1 for the Granite Mine in the section on hydrothermal alteration dates). Other small plutons of similar but slightly younger age are mapped in adjacent Anchorage quadrangle north of map area

Tgh Granitic rocks of Harding Icefield region (Eocene and Paleocene) -Primarily "medium- to dark-gray foliated medium- to coarse-grained biotite-muscovite-(hornblende) granite and granodiorite; marginal phases are locally biotite-muscovite-(hornblende) tonalite" (Tysdal and Case, 1979). Consists of a large batholith extending from Nuka and Aialik Bays and offshore islands northward more than $60 \mathrm{~km}$ into Harding Icefield where unit is exposed in many nunataks and westward into Seldovia quadrangle near Harris Bay; “* * * mafic minerals, almost wholly biotite, constitute 20 to 30 percent of minerals in tonalitic rocks, 15 to 20 percent of granodiorite, and 5 to 10 percent of granite; muscovite, a late but primary mineral, commonly makes up less than 2 percent" (Tysdal and Case, 1979). Unit includes Nuka, Aialik, and Tustumena plutons, and Chernof stock of Bradley and others (1999). A K-Ar

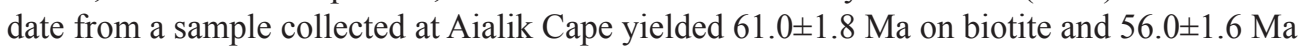
on muscovite (Tysdal and Case, 1979, ages recalculated using constants of Steiger and Jager, 1977), whereas a sample of the Aialik pluton from Harris Bay yielded a weighted mean ${ }^{40} \mathrm{Ar} /{ }^{39} \mathrm{Ar}$ age of 52.2 $\pm 0.9 \mathrm{Ma}$ (Bradley and others, 2000) and the Paguna stock of Bradley and others (1999) yielded a ${ }^{40} \mathrm{Ar} / 39 \mathrm{Ar}$ plateau age of $53.4 \pm 1.5 \mathrm{Ma}$. The apparent large size of the pluton and wide-ranging age determinations (from 52.2 to 61.0 Ma), which overlap the age of unit Tgg, suggest these rocks are part of a multiphase batholith rather than a single pluton. Lytwyn and others (2000) described a suite of dikes (part of map unit TKd, herein) that they associate with the same ridge subduction related system thought responsible for these plutons

Ophiolitic rocks of Prince William Sound (Eocene) - The ophiolitic rocks of Prince William Sound are composed of ultramafic rocks, gabbro, plagiogranite, sheeted basalt dikes, and pillow basalts that represent mid-oceanic-ridge rocks (Crowe and others, 1992; Tysdal and others, 1977) and are generally considered part of the Orca Group. These ophiolitic rocks crop out in a fault(?) bounded window in the Valdez Group along the Resurrection Peninsula and are interbedded and intruded within the Orca Group sedimentary rocks on Knight and Glacier Islands and to the northwest to Valdez Arm. The chemistry of the mafic rocks indicates a mid-ocean-ridge origin (Crowe and others, 1992; Tysdal and others, 1977; Lytwyn and others, 1997). An aeromagnetic high, associated with the ophiolitic rocks of Knight Island, extends to similar rocks on Glacier Island, which suggests the ophiolite is a continuous belt through Prince William Sound (Case and others, 1979; Barnes, 1991).

Historically, the Resurrection Peninsula rocks had been included within the Upper Cretaceous Valdez Group, although age control was lacking. With the report of a $57 \mathrm{Ma}$ age on a zircon from a plagiogranite (Nelson and others, 1989), it was recognized that Resurrection Peninsula rocks are similar in age to the Knight Island ophiolite, which is assigned to the Orca Group. Workers have consistently commented on the similarities between the two ophiolitic complexes (Tysdal and others, 1977; Tysdal and Case, 1979; Miller, 1984; Nelson and others, 1985; Lytwyn and others, 1997). Grant and Higgins (1910) originally showed these two ophiolitic complexes as part of the same unit. Because the units are the same age and are similar in character, herein we include Resurrection Peninsula ophiolitic rocks and Knight Island ophiolitic rocks as part of the Orca Group. Resurrection Peninsula 
ophiolitic rocks represent a single-sided west-dipping sequence (Tysdal and others, 1977). Knight Island ophiolitic rocks represent a mirrored or antiformal sequence having a core of gabbro cut by sheeted dikes with tops of pillow basalt on the west facing west and tops of pillow basalt on the east facing east (Tysdal and others, 1977). Although these ophiolitic rocks might be mapped as a separate unit from the Orca Group trench fill sedimentary rocks, the interfingering nature of the contact makes assigning a definitive demarcation difficult. Following Lytwyn and others (1997), we include the metavolcanic rocks described by Winkler and Plafker $(1981 ; 1993$, unit Tov) included in the Orca Group in the Cordova quadrangle in the ophiolitic rocks of Prince William Sound. On the Resurrection Peninsula, the contact between the Valdez Group and the ophiolitic rocks is in dispute (Bradley and Miller, 2006; Kusky and Young, 1999). Bradley and Miller (2006) interpreted the contact between the Valdez Group and the ophiolitic rocks as faulted on all sides. Kusky and Young (1999) interpreted the contact as stratigraphic on the west side of the peninsula near Humpy and Thumb Coves. Complicating matters are tuffaceous rock outcrops on Fox Island, which are petrographically and metamorphically different from typical rocks of the Valdez Group (Bradley and Miller, 2006; Kusky and Young, 1999; Tysdal and Case, 1979) and are mapped as a distinct unit of the Valdez Group by all workers. Also, Tysdal and Case (1979) map an intrusive contact between gabbroic and sedimentary rocks of the Valdez Group. Tysdal and Case (1979) mentioned a chilled margin and a 200-m-wide thermal aureole along the contact on the east side of the peninsula, but this was not observed by Nelson and others (1985). Tysdal and Case (1979) also mention an intrusive contact near the pass at the head of Likes Creek. Future study of the tuffaceous rocks and the contact between the ophiolitic rocks and surrounding sedimentary rocks is necessary to resolve the controversy regarding placement of the ophiolitic rocks in the section.

Tov Volcanic rocks, undivided (Eocene) - "Thick and thin tabular bodies of altered tholeiitic basalt consist of pillowed, massive, or crudely columnar flows, but also include pillow breccia, aquagene tuff, and diabase or gabbro sills; pillows have chilled margins that are palagonitic and amygdaloidal. Minor mudstone and siltstone that have interbedded basalt are included locally. Commonly contains green, gray, or red chert in interstices between pillows, rarely includes interpillow clots of pink limestone or black mudstone. $* * *$ Metamorphosed to zeolite or prehnite-pumpellyite facies" (Winkler and Plafker, 1993). Unit also includes areas mapped as greenstone that were probably pillow basalt, basaltic tuff, and sills (Tysdal and Case, 1979, unit Tog; Nelson and others, 1985, unit Tov). May be equivalent in part to units Top, Tovs, and Tod. Locally subdivided into:

Top Pillow basalt- -Pale- to dark-green aphyric to porphyritic, frequently amygdaloidal, pillow basalt composed of plagioclase and clinopyroxene; plagioclase commonly replaced by albite and epidote, and clinopyroxene by hornblende, actinolite, and(or) chlorite; vesicles mostly filled with chlorite; pillow basalt in some areas is interlayered with subordinate pillow breccia and tuff" (Tysdal and Case, 1979). Discrete pillows average $2 \mathrm{ft}[50 \mathrm{~cm}]$ in diameter on Resurrection Peninsula and average about $1 \mathrm{~m}$ where they were mapped in the Orca Group by Nelson and others (1985) and are metamorphosed to as high as low greenschist facies (Nelson and others, 1985). Fractured surfaces, chilled margins, palagonitic coatings, and cracks that radiate outward from pillow centers indicate rapid cooling (Tysdal and others, 1977; Tysdal and Case, 1979). Altered brown-colored volcanic glass makes up much of the matrix, especially in the outer parts of pillows (Nelson and others, 1985). Inter-pillow material consists of extrusive breccia, agglomerate, and hyaloclastite and, locally, thin sequences of siliceous mudstone and argillite, sandstone, and carbonate rocks, and minor red, green, and gray chert (Capps, 1915; Tysdal and others, 1977; Tysdal and Case, 1979; Miller, 1984; Nelson and others, 1985). Interbedded sedimentary layers locally display crossbedding and graded beds (Tysdal and others, 1977; Tysdal and Case, 1979). "Pillow basalt and lesser massive basalt and broken pillow breccia make up most of the western flank of the mafic complex on the Resurrection Peninsula" (Nelson and others, 1985; Tysdal and Case, 1979) where flows dip westward roughly $30^{\circ}$ and are as much as $1,000 \mathrm{~m}$ thick (Tysdal and others, 1977). Flows dip westward on the west side of Knight Island and eastward on the east side of the island and are more than 5,000 m thick (Tysdal and others, 1977). Unit is gradational into and cut by sheeted dikes of unit Tod over a wide zone on Glacier and Knight Islands and interbedded with volcanic and sedimentary rocks of unit Tovs in eastern Prince William Sound (Nelson and others, 1985; Tysdal and Case, 1979) 
Volcanic and sedimentary rocks - Consists of locally variable amounts of tholeiitic basalt and tuffaceous and generally minor turbiditic sedimentary rocks (Winkler and Plafker, 1993; Nelson and others, 1985; Tysdal and others, 1976). Lithology is quite variable throughout map area. "Basalt consists of pillowed and massive flows, pillow breccia, and tuff. Turbidites, in most places, are mudstone, siltstone, and fossiliferous volcanogenic sandstone; in a few places nonvolcanogenic sandstone is interbedded" (Winkler and Plafker, 1993). "In the Ragged Mountains of the Cordova quadrangle, volcaniclastic and tuffaceous sedimentary rocks are abundant, and pillow basalt is rare" (Nelson and others, 1985; Tysdal and others, 1976). In Ragged Mountains area, lower part of unit is interlayered with abundant aquagene tuff, tuff breccia, and calcareous sandstone containing shells (Tysdal and others, 1976).

Another variation of the unit is found north of Martin River where Nelson and others (1985) mapped a unit, Tots, consisting of tuffaceous sedimentary rocks, volcaniclastic sandstone, and minor chert. Majority of Tots unit is found south of Martin Fault where minor pillow basalt and abundant volcanic breccia is included with the sedimentary rocks of the unit and the "rocks are altered to a bright orange-weathering gossan $* * *$ intruded by numerous porphyritic dikes for a distance of $10 \mathrm{mi}$ along the south side of the Martin fault" (Nelson and others, 1985). As shown here, in vicinity of Knight Island, map unit is composed as much as 92 percent volcanic rocks; in this area these were mapped by Tysdal and Case (1979) as a pillow basalt and sedimentary rocks unit (Tops) and a greenstone and sedimentary rocks unit (Togs); and by Nelson and others (1985) as a pillow basalt and sedimentary rocks unit (Tops). Nelson and others (1985) distinguished the pillow basalt and sedimentary rocks unit from a separately mapped interbedded sedimentary and mafic volcanic rocks unit (Tosv) on the basis of the predominance of pillow basalt in the section; however, we have combined the units herein. Locally, this combined unit is marginal to and probably gradational to thicker sequences composed of pillowed and massive basalt flows (Top). Nelson and others (1985) reported a number of varieties of foraminifers of Paleocene to late middle Eocene age in Seward and Cordova quadrangles, and north of Martin River the tuffaceous sedimentary rocks contain locally abundant radiolarians and diatoms of late Paleocene to Eocene age

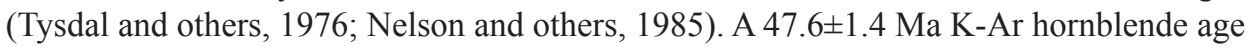
from a greenschist sample (table 1, sample number 71 Apr 23A, Winkler and Plafker, 1981; George Plafker field notebook, 1971; Nelson and others, 1985) collected from the head of Port Fidalgo in Cordova quadrangle was originally assigned to the Valdez Group by Winkler and Plafker (1981) and Nelson and others (1985); however, Winkler and Plafker (1993) reassigned rocks in the vicinity of this sample to the Orca Group, which would constrain the age of this unit to no younger than early Eocene

Tod Sheeted basalt dikes-Mafic sheeted-dike complexes consisting of dark-green, gray, and brown, aphanitic to porphyritic, chiefly basaltic, but locally gabbroic to dioritic, dikes (Tysdal and others, 1977; Tysdal and Case, 1979). In Knight Island area, felsic plagioclasequartz dikes occur locally and plagioclase-clinopyroxene-olivine dikes are present but not common (Tysdal and Case, 1979). On Resurrection Peninsula, olivine is present in a few dikes (Tysdal and Case, 1979). Dikes are commonly 1 to $2 \mathrm{~m}$ thick, vertical or nearly so, and generally strike north (Tysdal and others, 1977; Tysdal and Case, 1979). Dikes contain greenschist facies mineral assemblages ascribed to ocean-floor metamorphism (Bradley and Miller, 2006); according to Tysdal and Case (1979), plagioclase replaced by albite, clinopyroxene by hornblende and actinolite, and olivine partly altered to serpentine. Dikes crosscut one another, intrude the adjacent pillow basalt (unit Top), and on Knight Island, dikes locally intrude sedimentary rocks of Orca Group (Tysdal and others, 1977). Double- and single-sided chilled margins observed on dikes indicate a spreading center setting (Bradley and Miller, 2006; Tysdal and Case, 1979). Pillow basalt screens are common in the up-to2,000-m-wide transition zone between pillow basalt and sheeted dike units (Top and Tod) (Tysdal and others, 1977; Tysdal and Case, 1979; Miller, 1984; and Bradley and Miller, 2006). Xenoliths of gabbro and peridotite are present locally on Knight Island (Richter, 1965; Nelson and others, 1985). Small irregular pods, veins, and dikes of plagiogranite are also present in dike complex north of Bay of Isles on Knight Island (Nelson and others, 1985). Dikes are intruded by and also intrude gabbro in transition zone between gabbro and sheeted dike units (Togb and Tod) (Tysdal and Case, 1979; Tysdal and others, 1977). Dikes make up the topographically high and rugged cores of the Resurrection Peninsula, Knight Island, and Glacier Island (Tysdal and others, 1977). Whole rock K-Ar ages on greenstone 
reported by Miller (1984) are 35.0 $\pm 1.3 \mathrm{Ma}$ and 38.8 $\pm 1.9 \mathrm{Ma}$ on Knight Island and 49.6 \pm 2.5 $\mathrm{Ma}, 45.7 \pm 2.3 \mathrm{Ma}$, and 47.3 $\pm 2.4 \mathrm{Ma}$ on Resurrection Peninsula. Miller (1984) interpreted ages to represent minimum ages of accretion, reflecting argon loss due to heating

Togb Gabbro - "Medium- and dark-gray to green coarse-grained chiefly clinopyroxene-plagioclase rocks with ophitic to subophitic texture and gabbroic to dioritic composition; locally pegmatitic with clinopyroxene crystals as much as $5 \mathrm{~cm}$ long; clinopyroxene commonly is partly replaced by uralitic amphibole and chlorite; plagioclase is partly replaced by albite; epidote and minor opaque minerals are common" (Tysdal and Case, 1979). Several small intrusive bodies of gabbro occur on Knight Island, the largest crops out east of Drier Bay, where gabbro intrudes sheeted dikes (Nelson and others, 1985). Other gabbro bodies, too small to show at map scale, are elongate parallel to trend of the sheeted dikes. At north end of Latouche Island, a 30-m-wide exposure of gabbro intrudes slate and sandstone that is cut by several small gabbro-pegmatite dikes (Grant and Higgins, 1910, p. 49-50; Tysdal and Case, 1979; Nelson and others, 1985). On Resurrection Peninsula, Miller (1984) described local occurrences of west-dipping magmatic mineral layering and cumulate textures within the gabbro. Dikes and plugs of fine- to medium-grained plagiogranite (Miller, 1984; Bradley and Miller, 2006), the largest of which crop out northwest of head of Drier Bay on Knight Island and south side of Killer Bay on Resurrection Peninsula (Tysdal and Case, 1979; Miller, 1984). Gabbro grades into sheeted dike unit (Tod herein) and is generally elongate and parallel to the sheeted dikes, but also crosscuts dikes locally (Tysdal and Case, 1979; Miller, 1984). Tysdal and Case (1979) state that on Resurrection Peninsula, "The gabbro intrudes slate and sandstone of the Valdez Group, crosscuts the bedding, and forms aphanitic sills in other places. A blue-gray and whitish thermal aureole, at least $200 \mathrm{~m}$ wide, marks the contact zone with the sedimentary rocks." However, Nelson and others (1985) and Bradley and Miller (2006) interpreted contacts between the gabbro and Valdez metasedimentary rocks as faults. On Knight Island, gabbro intrudes rocks of the Orca Group. Nelson and others (1989) reported a $57 \mathrm{Ma} \mathrm{U}-\mathrm{Pb}$ zircon age on a plagiogranite intruding gabbro on Resurrection Peninsula

Tou Ultramafic rocks - "Dunite, locally with layers of chromite, moderately altered to mostly altered to serpentine, serpentine-talc, and talc schist; lustrous pale- to dark-green and black, locally reddish weathering rock that forms dike-like and irregularly shaped intrusive bodies" (Tysdal and Case, 1979) on Resurrection Peninsula. "In most places enough relict texture and mineralogy remains to recognize original clinopyroxenite, dunite, and harzburgite" (Miller, 1984). Occurs as small pods in gabbro and fault-bounded slices within Valdez Group metasedimentary rocks (Miller, 1984; Nelson and others, 1985). On Knight Island, xenoliths of peridotite in sheeted dikes were observed by Richter (1965) but not by subsequent workers (Tysdal and Case, 1979; Nelson and others (1985). However, Nelson and others (1985) mapped three peridotite bodies; two lie within or near a shear zone in the sheeted dikes unit (Tod), the other occurs as a xenolith in sheeted dikes unit. Weathers orangish brown and forms subdued rubble outcrops

Tmu Mafic and ultramafic plutonic rocks (Eocene and Paleocene?) - "Compositionally and texturally variable unit consists mainly of clinopyroxene gabbro, two-pyroxene gabbro, and local diabase, hornblende gabbro, peridotite, and orthopyroxenite. Gabbro commonly is medium-grained and equigranular and is slightly to moderately foliated except near contacts with country rocks where it locally is strongly foliated or mylonitic" (Winkler and Plafker, 1993). In Cordova quadrangle, near head of Port Fidalgo, Nelson and others (1985) mapped a small area of blocks of both banded and massive dark- to light-green serpentinized dunite and peridotite that crop out within metasedimentary rocks unit of Valdez Group (Kvs). Strongly sheared margins in dunite and peridotite suggest blocks have been tectonically emplaced (Nelson and others, 1985). Within country rocks of Orca Group, the intrusions commonly have well-developed thermal aureoles; in sedimentary rocks, intrusions have prominent zones of iron-staining (Winkler and Plafker, 1993). Winkler and Plafker (1993) considered age of unit as uncertain; two hornblende K-Ar ages of $64.5 \pm 2.1$ and $48.5 \pm 1.5 \mathrm{Ma}$ were reported; the older age was considered suspect because it is older than the Orca Group, which unit Tmu intrudes

TKd Dikes (early Tertiary to Early Cretaceous) - Dikes of dacite, rhyolite, andesite, and rare basalt intrude rocks of the Valdez Group (Kvs) and McHugh Complex (KMm) (Bradley and others, 1999). Analyzed samples of dikes yield a wide range of ages, as shown in table 
1. A basaltic-andesite dike intruding McHugh Complex yielded an ${ }^{40} \mathrm{Ar} / 39 \mathrm{Ar}$ hornblende plateau age of $115 \pm 2 \mathrm{Ma}$, whereas an intermediate composition dike yielded an ${ }^{40} \mathrm{Ar} / 39 \mathrm{Ar}$ isochron(?) age of 57.0 $\pm 0.22 \mathrm{Ma}$ (W. Clendenin, written commun., cited in Bradley and others, 1999). Felsic dikes mapped by Nelson and others (1999) yielded a $40 \mathrm{Ar} / 39 \mathrm{Ar}$ isochron age as young as $31.1 \pm 0.2 \mathrm{Ma}$ on potassium feldspar, as well as a ${ }^{40} \mathrm{Ar} / 39 \mathrm{Ar}$ plateau of $38.6 \pm 0.6 \mathrm{Ma}$ on biotite and a ${ }^{40} \mathrm{Ar} / 39 \mathrm{Ar}$ disturbed age of $40 \pm 1 \mathrm{Ma}$, also on biotite. Lytwyn and others (2000) described a suite of dikes ranging in composition from basalt to rhyolite that they associated with the near-trench intrusions commonly related to the subduction of the Kula-Farallon spreading center; a ${ }^{40} \mathrm{Ar} / 39 \mathrm{Ar}$ plateau amphibole age on andesite from this suite yielded an age of 58.64 $\pm 0.52 \mathrm{Ma}$. Lytwyn and others (2000) considered the dikes they studied to represent the same system as the plutons we have included in map unit Tgh here. Even discounting the potassium feldspar age as a minimum age, data indicate that the dikes include rocks of multiple ages, possibly representing multiple events throughout the region

\section{References Cited}

Addicott, W.O., and Plafker, George, 1971, Paleocene mollusks from the Gulf of Alaska Tertiary province-A significant new occurrence on the North Pacific Rim, in Geological Survey Research 1971: U.S. Geological Survey Professional Paper 750-B, p. B48-B52.

Addicott, W.O., Winkler, G.R., and Plafker, George, 1978, Preliminary megafossil biostratigraphy and correlation of selected stratigraphic sections in the Gulf of Alaska's Tertiary province: U.S. Geological Survey Open-File Report 78-491, 2 sheets.

Barnes, D.F., 1991, Map showing geologic interpretation of aeromagnetic data for the Chugach National Forest, Alaska: U.S. Geological Survey Miscellaneous Field Studies Map MF-1645H, 8 p., 1 sheet, scale 1:250,000.

Berg, H.C., Jones, D.L., and Richter, D.H., 1972, GravinaNutzotin belt-Tectonic significance of an upper Mesozoic sedimentary and volcanic sequence in southern and southeastern Alaska, in Geological Survey Research 1972: U.S. Geological Survey Professional Paper 800D, p. D1-D24.

Bol, A.J., and Gibbons, Helen, 1992, Tectonic implications of out-of-sequence faults in an accretionary prism, Prince William Sound, Alaska: Tectonics, v. 11, no. 6, p. $1,288-1,300$.

Bol, A.J., and Roeske, S.M., 1993, Strike-slip faulting and block rotation along the Contact fault system, eastern Prince William Sound, Alaska: Tectonics, v. 12, no. 1, p. 49-62.

Bradley, D.C., Haeussler, P.J., and Kusky, T.M., 1993, Timing of early Tertiary ridge subduction in southern Alaska, in Dusel-Bacon, Cynthia, and Till, A.B., eds., Geologic studies by the U.S. Geological Survey, 1992: U.S. Geological Survey Bulletin 2068, p. 163-177.

Bradley, D.C., and Karl, S.M., 2000, Field guide to the Mesozoic accretionary complex in Kachemak Bay and Seldovia, south central Alaska: Anchorage, Alaska Geological Society, $19 \mathrm{p}$.

Bradley, D.C., Kusky, T.M., Haeussler, P.J., Karl, S.M., and Donley, D.T., 1999, Geology of the Seldovia quadrangle: U.S. Geological Survey Open-File Report 99-18, scale 1:250,000.

Bradley, D.C., and Miller, M.L., 2006, Field guide to south-cen- tral Alaska's accretionary complex Anchorage to Seward: Anchorage, Alaska Geological Society, 32 p.

Bradley, D.C., Parrish, Randall, Clendenen, William, Lux, Daniel, Layer, P.W., Heizler, Matthew, and Donley, D.T., 2000, New geochronological evidence for the timing of early Tertiary ridge subduction in southern Alaska, in Kelley, K.D., and Gough, L.P., eds., Geologic studies in Alaska by the U.S. Geological Survey, 1998: U.S. Geological Survey Professional Paper 1615, p. 5-21.

Bradley, D.C., and Wilson, F.H., 2000, Reconnaissance bedrock geology of the southeastern part of the Kenai quadrangle, Alaska, in Kelley, K.D., and Gough, L.P., eds., Geologic studies in Alaska: U.S. Geological Survey Professional Paper 1615, p. 59-64.

Calderwood, K.W., and Fackler, W.C., 1972, Proposed stratigraphic nomenclature for Kenai Group, Cook Inlet basin, Alaska: American Association of Petroleum Geologists Bulletin, v. 56, no. 4, p. 739-754.

Capps, S.R., 1915, Some ellipsoidal lavas on Prince William Sound, Alaska: Journal of Geology, v. 23, no. 1, p. 45-51.

Capps, S.R., 1937, Kodiak and adjacent islands, Alaska: U.S. Geological Survey Bulletin 880-C, p. 111-184, scale 1:250,000.

Carden, J.R., Connelly, W., Forbes, R.B., and Turner, D.L., 1977, Blueschists of the Kodiak Islands, Alaska-An extension of the Seldovia schist terrane: Geology, v. 5, p. 529-533.

Case, J.E., Tysdal, R.G., Hillhouse, J.W., Grommé, C.S., 1979, Geologic interpretation of aeromagnetic map of the Seward and Blying Sound quadrangles, Alaska: U.S. Geological Survey Miscellaneous Field Studies Map MF-880D, 2 sheets, scale 1:250,000.

Clark, S.H.B., 1981, Guide to the bedrock geology along the Seward highway north of Turnagain Arm: Anchorage, Alaska, Alaska Geological Society Publication no. 1, 36 p.

Committee on the Alaska Earthquake of the Division of Earth Sciences National Research Council, 1971, The Great Alaska Earthquake of 1964-Geology: Washington, D.C., National Academy of Sciences, $834 \mathrm{p}$.

Connelly, William, 1978, Uyak Complex, Kodiak Islands, Alaska: A Cretaceous subduction complex: Geological Society of America Bulletin, v. 89, no. 5, p. 755-769. 
Connelly, William, and Moore, J.C., 1979, Geologic map of the northwest side of the Kodiak and adjacent islands, Alaska: U.S. Geological Survey Miscellaneous Field Studies Map MF-1057, 2 sheets, scale 1:250,000.

Cowan, D.S., and Boss, R.F., 1978, Tectonic framework of the southwestern Kenai Peninsula, Alaska: Geological Society of America Bulletin, v. 89, p. 155-158.

Crowe, D.E., Nelson, S.W., Brown, P.E., Shanks, W.C., III, and Valley, J.W., 1992, Geology and geochemistry of volcanogenic massive sulfide deposits and related igneous rocks, Prince William Sound, south-central: Economic Geology, v. 87, no. 7, p. 1,722-1,746.

Crowell, A.L., and Mann, D.H., 1998, Archaeology and coastal dynamics of Kenai Fjords National Park, Alaska: National Park Service, Alaska Region Research/Resources Management Report ARRCR/CRR-98/34, 196 p., appendix 38 p.

Detterman, R.L., and Hartsock, J.K., 1966, Geology of the Iniskin-Tuxedni region, Alaska: U.S. Geological Survey Professional Paper 512, 78 p., 6 pls., scale 1:63,360.

Detterman, R.L., Hudson, Travis, Plafker, George, Tysdal, R.G., and Hoare, J.M., 1976, Reconnaissance geologic map along Bruin Bay and Lake Clark faults in Kenai and Tyonek quadrangles, Alaska: U.S. Geological Survey Open-File Report 76-477, scale 1:250,000.

Detterman, R.L., Miller, J.W., Case, J.E., Wilson, F.H., and Yount, M.E., 1996, Stratigraphic framework of the Alaska Peninsula: U.S. Geological Survey Bulletin 1969-A, 74 p.

Detterman, R.L., and Reed, B.L., 1980, Stratigraphy, structure, and economic geology of the Iliamna quadrangle, Alaska: U.S. Geological Survey Bulletin 1368-B, 86 p., 1 sheet, scale 1:250,000.

Detterman, R.L., Reed, B.L., and Lanphere, M.A., 1965, Jurassic plutonism in the Cook Inlet region, Alaska: U.S. Geological Survey Professional Paper 525-D, p. D16-D21.

Detterman, R.L., and Westermann, G.E.G., 1992, Southern Alaska, p. 49-57, in Poulton, T.P., Detterman, R.L., Hall, R.L., Jones, D.L., Peterson, J.A., Smith, P., Tayler, D.G., Tipper, H.W., and Westermann, G.E.G., Western Canada and United States, in Westermann, G.E.G., ed., The Jurassic of the Circum-Pacific, World and regional geology: Cambridge University Press, v. 3, p. 49-57.

Dumoulin, J.A., 1987, Sandstone composition of the Valdez and Orca Groups, Prince William Sound, Alaska: U.S. Geological Survey Bulletin 1774, 37 p.

Dumoulin, J.A., 1988, Sandstone petrographic evidence and the Chugach-Prince William terrane boundary in southern Alaska: Geology, v. 16, p. 456-460.

Flores, R.M., Stricker, G.D., and Bader, L.R., 1997, Stratigraphic architecture of the Tertiary alluvial Beluga and Sterling Formations, Kenai Peninsula, Alaska, in Karl, S.M., Vaughan, N.R., and Ryherd, T.J., eds., 1997 Guide to the geology of the Kenai Peninsula, Alaska: Anchorage, Alaska, Alaska Geological Society, p. 36-53.

Forbes, R.B., and Lanphere, M.A., 1973, Tectonic significance of mineral ages of blueschists near Seldovia, Alaska: Journal of Geophysical Research, v. 78, no. 8, p. 1,383-1,386.

Gehrels, G.E., and Berg, H.C., 1992, Geology of southeastern Alaska: U.S. Geological Survey Miscellaneous Investiga- tion Series Map I-1867, pamphlet 24 p., 1 sheet, scale $1: 600,000$.

Grant, U.S., and Higgins, D.F., 1910, Reconnaissance of the geology and mineral resources of Prince William Sound, Alaska: U.S. Geological Survey Bulletin 443, 88 p.

Haeussler, P.J., Bradley, D.C., Goldfarb, Richard, Snee, L.W., and Taylor, Cliff, 1995, Link between ridge subduction and gold mineralization in southern Alaska: Geology, v. 23, no. 11, p. 995-998.

Haeussler, P.J., and Saltus, R.W., 2005, $26 \mathrm{~km}$ of offset on the Lake Clark Fault since Late Eocene time, in Haeussler, P.J., and Galloway, J.P., eds., Studies by the U.S. Geological Survey in Alaska, 2004: U.S. Geological Survey Professional Paper 1709-A, 4 p. (online only, http://pubs. usgs.gov/pp/pp1709a/).

Helwig, J., and Emmet, P., 1981, Structure of the early Tertiary Orca Group in Prince William Sound and some implications for the plate tectonic history of southern Alaska: Journal of the Alaska Geological Society, v. 1, p. 12-35.

Hudson, Travis, Plafker, George, and Peterman, Z.E., 1979, Paleogene anatexis along the Gulf of Alaska margin: Geology, v. 7, p. 573-577.

Imlay, R.W., 1981, Early Jurassic ammonites from Alaska: U.S. Geological Survey Professional Paper 1148, 49 p., 12 pls.

Jones, D.L., and Silberling, N.J., 1979, Mesozoic stratigraphyThe key to tectonic analysis of southern and central Alaska: U.S. Geological Survey Open-File Report 79-1200, 39 p.

Jones, D.L., Silberling, N.J., Berg, H.C., and Plafker, George, 1981, Map showing tectonostratigraphic terranes of Alaska, columnar sections, and summary description of terranes: U.S. Geological Survey Open-File Report 81-792, 20 p., 2 sheets, scale 1:2,500,000.

Karlstrom, T.N.V., 1964, Quaternary geology of the Kenai Lowland and glacial history of the Cook Inlet region, Alaska: U.S. Geological Survey Professional Paper 443, 69 p., 7 pls., various scales.

Kelley, J.S., 1980, Environments of deposition and petrography of Lower Jurassic volcaniclastic rocks, southwestern Kenai Peninsula, Alaska: Davis, California, University of California, $304 \mathrm{p}$.

Kelley, J.S., 1984, Geologic map and sections of the southwestern Kenai Peninsula west of the Port Graham fault, Alaska: U.S. Geological Survey Open-File Report 84-152, 1 sheet, scale 1:63,360.

Kirschner, C.E., and Lyon, C.A., 1973, Stratigraphic and tectonic development of Cook Inlet petroleum province, in Pitcher, M.G., ed., Arctic geology: American Association of Petroleum Geologists Memoir 19, p. 396-407.

Kusky, T.M., Bradley, D.C., Haeussler, P.J., and Karl, S.M., 1997, Controls on accretion of flysch and melange belts at convergent margins: Evidence from the Chugach Bay thrust and Iceworm melange, Chugach accretionary wedge, Alaska: Tectonics, v. 16, no. 6, p. 855-878.

Kusky, T.M., and Young, C.P., 1999, Emplacement of the Resurrection Peninsula ophiolite in the southern Alaska forearc during a ridge-trench encounter: Journal of Geophysical Research, v. 104, no. B12, p. 28,025-29,054. 
Lanphere, M.A., 1966, Potassium-argon ages of Tertiary plutons in the Prince William Sound region, Alaska, in Geological Survey Research 1966: U.S. Geological Survey Professional Paper 550-D, p. D195-D198.

Leopold, L.E., editor-in-chief, 1969, The Prince William Sound, Alaska, earthquake of 1964 and aftershocks, Volume II Research Studies: Seismology and marine geology, Parts B Seismology and Part C Marine geology: U.S. Department of Commerce, Environmental Science Services Administration, Coast and Geodetic Survey, Publication 10-3, v. 2 part B and C, $350 \mathrm{p}$.

Lytwyn, Jennifer, Casey, John, Gilbert, Susan, and Kusky, Timothy, 1997, Arc-like mid-ocean ridge basalt formed seaward of a trench-forearc system just prior to ridge subduction: An example from subaccreted ophiolites in southern Alaska: Journal of Geophysical Research, v. 102, no. B5, p. 10,225-10,243.

Lytwyn, Jennifer, Lockhart, Susan, Casey, John, and Kusky, Timothy, 2000, Geochemistry of near-trench intrusives associated with ridge subduction, Seldovia quadrangle, southern Alaska: Journal of Geophysical Research, v. 105, no. B12, p. 27,957-27,978.

MacNeil, F.J., Wolfe, J.A., Miller, D.J., and Hopkins, D.M., 1961, Correlation of Tertiary formations of Alaska: American Association of Petroleum Geologists Bulletin, v. 45, p. $1,801-1,809$.

Magoon, L.B., Adkison, W.L., and Egbert, R.M, 1976, Map showing geology, wildcat wells, Tertiary plant localities, $\mathrm{K}-\mathrm{Ar}$ age dates, and petroleum operations, Cook Inlet area, Alaska: U.S. Geological Survey Miscellaneous Investigations Series Map I-1019, scale 1:250,000, 3 sheets.

Magoon, L.B., and Egbert, R.M., 1986, Framework geology and sandstone composition, in Magoon, L.B., ed., Geologic studies of the Lower Cook Inlet COST No. 1 Well, Alaska Outer Continental Shelf: U.S. Geological Survey Bulletin 1596, p. 65-90.

Magoon, L.B., Griesbach, F.B., and Egbert, R.M., 1980, Nonmarine Upper Cretaceous rocks, Cook Inlet, Alaska: American Association of Petroleum Geologists Bulletin, v. 64 , no. 8 , p. $1,259-1,266$.

Martin, G.C., 1905, Notes on the petroleum fields of Alaska: U.S. Geological Survey Bulletin 259, p. 128-139.

Martin, G.C., 1908, Geology and mineral resources of the Controller Bay region, Alaska: U.S. Geological Survey Bulletin 335, $141 \mathrm{p}$.

Martin, G.C., 1915, The western part of the Kenai Peninsula, in Martin, G.C., Johnson, B.L, and Grant, U.S., Geology and mineral resources of Kenai Peninsula, Alaska: U.S. Geological Survey Bulletin 587, p. 41-111.

Martin, G.C., 1926, The Mesozoic stratigraphy of Alaska: U.S. Geological Survey Bulletin 776, 493 p.

Martin, G.C., Johnson, B.L., and Grant, U.S., 1915, Geology and mineral resources of Kenai Peninsula, Alaska: U.S. Geological Survey Bulletin 587, 243 p.

Martin, G.C., and Katz, F.J., 1912, A geologic reconnaissance of the Iliamna region, Alaska: U.S. Geological Survey Bulletin $485,138 \mathrm{p}$.

Miller, D.J., 1951, Preliminary report on the geology and oil possibilities of the Katalla district, Alaska: U.S. Geological Survey Open-File Report 50-20, 66 p., 4 sheets, scale $1: 96,000$.

Miller, D.J., 1961, Geology of the Katalla district, Gulf of Alaska Tertiary province, Alaska: U.S. Geological Survey Open-File Report 61-99, 2 sheets, scale 1:96,000.

Miller, D.J., 1975, Geologic map and sections of the central part of the Katalla district, Alaska: U.S. Geological Survey Miscellaneous Field Studies Map MF-722, 2 sheets, scale $1: 40,000$.

Miller, M.L., 1984, Geology of the Resurrection Peninsula, in Winkler, G.R., Miller, M.L., Hoekzema, R.B., and Dumoulin, J.A., eds., Guide to the bedrock geology of a traverse of the Chugach Mountains from Anchorage to Cape Resurrection: Anchorage, Alaska, Alaska Geological Society Guidebook, p. 25-34.

Mitchell, P.A., Silberman, M.L., and O’Neil, J.R., 1981, Genesis of gold vein mineralization in an Upper Cretaceous turbidite sequence, Hope-Sunrise district, southern Alaska: U.S. Geological Survey Open-File Report 81-103, 18 p.

Moffat, F.H., 1954, Geology of the Prince William Sound region, Alaska: U.S. Geological Survey Bulletin 989-E, p. 225-310.

Nelson, S.W., Blome, C.D., Harris, A.G., Reed, K.M., and Wilson, F.H., 1986, Later Paleozoic and Early Jurassic fossil ages from the McHugh Complex, in BartschWinkler, Susan, and Reed, K.M., eds., Geologic studies in Alaska by the U.S. Geological Survey during 1985: U.S. Geological Survey Circular 978, p. 60-64.

Nelson, S.W., Dumoulin, J.A., and Miller, M.L., 1985, Geologic map of the Chugach National Forest: U.S. Geological Survey Miscellaneous Field Studies Map MF-1645B, scale $1: 250,000$.

Nelson, S.W., Miller, M.L., and Dumoulin, J.A., 1989, The Resurrection Peninsula ophiolite, in Nelson, S.W. and Hamilton, T.D., eds., Guide to the geology of the Resurrection Bay-eastern Kenai Fjords area: Anchorage, Alaska, Alaska Geological Society, p. 10-18.

Nelson, S.W., Miller, M.L., Haeussler, P.J., Snee, L.W., Phillips, P.J., and Huber, Carol, 1999, Preliminary geologic map of the Chugach National Forest Special Study Area, Alaska: U.S. Geological Survey Open-File Report 99-362, scale $1: 63,360$.

Nelson, W.H., Carlson, Christine, and Case, J.E., 1983, Geologic map of the Lake Clark quadrangle, Alaska: U.S. Geological Survey Miscellaneous Field Studies Map MF1114A, scale 1:250,000.

Nilsen, T.H., and Zuffa, G.G., 1982, The Chugach terrane, a Cretaceous trench-fill deposit, southern Alaska, in Leggett, J.K., ed., Trench-forearc geology; sedimentation and tectonics on modern and ancient active plate margins conference: Geological Society of London Special Publication 10, p. 213-227.

Nokleberg, W.J., Plafker, George, and Wilson, F.H., 1994, Geology of south-central Alaska, in Plafker, George, Jones, D.L., and Berg, H.C., eds., Geology of Alaska: Geological Society of America, The Geology of North America, Boulder, Colorado, v. G-1, p. 311-366. 
Plafker, George, 1969, Tectonics of the March 27, 1964, Alaska Earthquake: U.S. Geological Survey Professional Paper 543-I, 74 p.

Plafker, George, 1971, Possible future petroleum resources of Pacific-margin Tertiary basin, Alaska, in Future petroleum provinces of North America: American Association of Petroleum Geologists Memoir 15, p. 120-135.

Plafker, George, 1974, Preliminary geologic map of Kayak and Wingham Islands, Alaska: U.S. Geological Survey OpenFile Report 74-82, scale 1:31,680.

Plafker, George, 1987, Regional geology and petroleum potential of the northern Gulf of Alaska continental margin, in Scholl, D.W., Grantz, Arthur, and Vedder, J.A., Geology and resource potential of the continental margin of western North America and adjacent ocean basins, Beaufort Sea to Baja California: Circum-Pacific Council for Energy and Mineral Resources Earth Science Series, v. 6, p. 229-267.

Plafker, George, 1990, Regional geology and tectonic evolution of Alaska and adjacent parts of the northeast Pacific Ocean margin: Proceedings of the Pacific Rim Congress 90: Queensland, Australia, Australasian Institute of Mining and Metallurgy, p. 841-853.

Plafker, George, and Addicott, W.O., 1976, Glaciomarine deposits of Miocene through Holocene age along the Gulf of Alaska margin, Alaska: U.S. Geological Survey OpenFile Report 76-84, 36 p.

Plafker, George, Bruns, T.R., and Page, R.A., 1975a, Interim report on petroleum resource potential and geologic hazards in the outer-continental shelf of the Gulf of Alaska Tertiary province: U.S. Geological Society Open-File Report 75-592, $74 \mathrm{p}$.

Plafker, George, Detterman, R.L., and Hudson, Travis, 1975b, New data on the displacement history of the Lake Clark Fault, in Yount, M.E., ed., United States Geological Survey Alaska Program, 1975: U.S. Geological Survey Circular 722 , p. 44-45.

Plafker, George, Jones, D.L., and Pessagno, E.A., Jr., 1977, A Cretaceous accretionary flysch and melange terrane along the Gulf of Alaska margin, in Blean, K.M., ed., The United States Geological Survey in Alaska; Accomplishments during 1976: U.S. Geological Survey Circular 751-B, p. B41-B43.

Plafker, George, Keller, Gerta, Nelson, S.W., Dumoulin, J.A., and Miller, M.L., 1985, Summary of data on the age of the Orca Group, Alaska, in Bartsch-Winkler, Susan, ed., The United States Geological Survey in Alaska; Accomplishments during 1984: U.S. Geological Survey Circular 967, p. 74-76.

Plafker, George, and Lanphere, M.A., 1974, Radiometrically dated plutons cutting the Orca Group, in Carter, Claire, ed., U.S. Geological Survey Alaskan Program, 1974: U.S. Geological Survey Circular 700, p. 53.

Plafker, George, Moore, J.C., and Winkler, G.R., 1994, Geology of the southern Alaska margin, in Plafker, George, and Berg, H.C., eds., The geology of Alaska: Boulder, Colorado, Geological Society of America, The Geology of North America, v. G-1, p. 389-449.

Plafker, George, and Page, R.A., 1994, The Great 1964 Alaska earthquake; a 30-year perspective: Seismological Research Letters, v. 65, no. 3-4, 239 p.

Plafker, George, and Rubin, Meyer, 1978, Uplift history and earthquake recurrence as deduced from marine terraces on Middleton Island, Alaska, in Proceedings of Conference VI, Methodology for identifying seismic gaps and soonto-break gaps: U.S. Geological Survey Open-File Report 78-943, p. 687-721.

Poole, A.R., 1996, Age and geochemical constraints on ridge subduction for igneous rocks of the eastern Chugach Mountains, Alaska: Houston, Rice University, unpublished Master's thesis, 83 p.

Post, Austin, 1967, Effects of the March 1964 Alaska earthquake on glaciers: U.S. Geological Survey Professional Paper 544-D, p. D1-D42.

Rau, W.W., Plafker, George, and Winkler, G.R., 1977, Preliminary foraminiferal biostratigraphy and correlation of selected stratigraphic sections and wells in the Gulf of Alaska Tertiary Province: U.S. Geological Survey OpenFile Report 77-747, 54 p., 3 sheets.

Reed, B.L., and Lanphere, M.A., 1969, Age and chemistry of Mesozoic and Tertiary plutonic rocks in south-central Alaska: Geological Society of America Bulletin, v. 80, p. 23-44.

Reed, B.L., and Lanphere, M.A., 1972, Generalized geologic map of the Alaska-Aleutian Range batholith showing K/Ar ages of the plutonic rocks: U.S. Geological Survey Miscellaneous Field Studies Map MF-372, scale 1:1,000,000.

Reed, B.L., and Lanphere, M.A., 1973, Alaska-Aleutian Range batholith: geochronology, chemistry, and relation to circum-Pacific plutonism: Geological Society of America Bulletin, v. 84, p. 2,583-2,610.

Reed, B.L., Lanphere, M.A., and Miller, T.P., 1992, Double Glacier volcano, a 'new' Quaternary volcano in the eastern Aleutian volcanic arc: Bulletin of Volcanology, v. 54, p. 631-637.

Reed, B.L., Miesch, A.T., and Lanphere, M.A., 1983, Plutonic rocks of Jurassic age in the Alaska-Aleutian Range batholith: chemical variations and polarity: Geological Society of America Bulletin, v. 94, p. 1,232-1,240.

Richter, D.H., 1965, Geology and mineral deposits of central Knight Island, Prince William Sound, Alaska: Alaska Division of Mines and Minerals Geologic Report 16, 37 p., 1 sheet, approximate scale 1:42,240.

Richter, D.H., Preller, C.C., Labay, K.A., and Shew, N.B., 2005, Geology of Wrangell-Saint Elias National Park and Preserve, southcentral Alaska: U.S. Geological Survey Scientific Investigations Map 2877, scale 1:350,000.

Riehle, J.R., and Emmel, K.S., 1980, Photointerpretation map of the surficial geology, Polly Creek to MacArthur River, Cook Inlet, Alaska: Alaska Division of Geological and Geophysical Surveys Geologic Report 64, 2 sheets, scale $1: 63,360$.

Riehle, J.R., Kienle, Juergen, and Emmel, K.S., 1981, Lahars in Crescent River valley, lower Cook Inlet, Alaska: Alaska Division of Geological and Geophysical Surveys Geologic Report 53, 10 p.

Roeske, S.M., Mattinson, J.M., and Armstrong, R.L., 1989, 
Isotopic ages of glaucophane schists on the Kodiak Islands, southern Alaska, and their implications for the Mesozoic tectonic history of the Border Ranges fault system: Geological Society of America Bulletin, v. 101, p. 1,0211,037 .

Schrader, F.C., 1900, A reconnaissance of a part of Prince William Sound and the Copper River district, Alaska, in 1898: U.S. Geological Survey 20th Anniversary Report, pt. 7, p. 341-423.

Silberling, N.A., Grant-Mackie, J.A., and Nichols, K.M., 1997, The Late Triassic bivalve Monotis in accreted terranes of Alaska: U.S. Geological Survey Bulletin 2151, 21 p.

Silberman, M.L., Mitchell, P.A., O’Neil, J.R., 1981, Isotopic data bearing on the origin and age of the epithermal lode gold deposits in the Hope-Sunrise mining district, northern Kenai Peninsula, Alaska: U.S. Geological Survey Circular 823-B, p. B81-B84.

Sisson, V.B., and Onstott, T.C., 1986, Dating of blueschist metamorphism: A combined ${ }^{40} \mathrm{Ar} /{ }^{39} \mathrm{Ar}$ and electron microprobe approach: Geochimica et Cosmochimica Acta, v. 50, p. 2,111-2,117.

Spurr, J.E., 1900, A reconnaissance in southwestern Alaska in 1898: U.S. Geological Survey 20th Annual Report, part 7, p. 31-264.

Steiger, R.H., and Jager, E., 1977, Subcommission on geochronology: Convention on the use of decay constants in geo- and cosmochronology: Earth and Planetary Science Letters, v. 36, p. 359-362.

Stover, C.W., and Coffman, J.L., 1993, Seismicity of the United States, 1568-1989 (revised): U.S. Geological Survey Professional Paper 1527, $418 \mathrm{p}$.

Till, A.B., Yount, M.E., and Riehle, J.R., 1993, Redoubt Volcano, southern Alaska: A hazard assessment based on eruptive activity through 1968: U.S. Geological Survey Bulletin 1996, 19 p., 1 pl., scale 1:125,000.

Triplehorn, D.M., Turner, D.L., and Naeser, C.W., 1977, K-Ar and fission-track dating of ash partings in coal beds from the Kenai Peninsula, Alaska: A revised age for the Homerian Stage-Clamgulchian Stage boundary: Geological Society of America Bulletin, v. 88, no. 8, p. 1,156-1,160.

Turner, D.L., Triplehorn, D.M., Naeser, C.W., and Wolfe, J.A., 1980, Radiometric dating of ash partings in Alaska coal bed and upper Tertiary paleobotanical stages: Geology, v. 8, p. 92-96.

Tysdal, R.G., and Case, J.E., 1979, Geologic map of the Seward and Blying Sound quadrangles, Alaska: U.S. Geological Survey Miscellaneous Investigations Series Map I-1150, scale 1:250,000.

Tysdal, R.G., Case, J.E., Winkler, G.R., and Clark, S.H.B., 1977, Sheeted dikes, gabbro, and pillow basalt in flysch of coastal southern Alaska: Geology, v. 5, p. 377-383.

Tysdal, R.G., Hudson, Travis, and Plafker, George, 1976, Geologic map of the Cordova B-2 quadrangle and northern part of the Cordova A-2 quadrangle, south-central Alaska: U.S. Geological Survey Miscellaneous Field Studies Map MF-783, scale 1:63,360.

Tysdal, R.G., and Plafker, George, 1978, Age and continuity of the Valdez Group, southern Alaska, in Sohl, N.F., and
Wright, W.B., Changes in stratigraphic nomenclature by the U.S. Geological Survey, 1977: U.S. Geological Survey Bulletin 1457-A, p. A120-A124.

Waythomas, C.F., and Miller, T.P., 1999, Preliminary volcanohazard assessment for Iliamna Volcano: U.S. Geological Survey Open-File Report 99-373, 31 p. 1 pl., scale not reported.

Wilson, F.H., Detterman, R.L., and Case, J.E., 1985, The Alaska Peninsula terrane; a definition: U.S. Geological Survey Open-File Report 85-450, 17 p.

Wilson, F.H., Detterman, R.L., and DuBois, Gregory, 1999, Digital data for the geologic framework of the Alaska Peninsula, southwest Alaska, and the Alaska Peninsula terrane: U.S. Geological Survey Open-File Report 99-317 (online only at http://wrgis.wr.usgs.gov/open-file/of99-317/).

Wilson, F.H., Dover, J.H., Bradley, D.C., Weber, F.R., Bundtzen, T.K., and Haeussler, P.J., 1998, Geologic map of Central (Interior) Alaska: U.S. Geological Survey Open-File Report 98-133, 3 sheets, scale 1:500,000, 63-p. pamphlet, 13-p. appendix.

Wilson, F.H., Labay, K.A., Mohadjer, Solmaz, and Shew, Nora, 2005, Digital datasets for geologic map by Wilson, F.H.: Preliminary integrated geologic map databases for the United States; digital data for the reconnaissance geologic map for the Kodiak Islands, Alaska: U.S. Geological Survey Open-File Report 2005-1340 (online only at http:// pubs.usgs.gov/of/2005/1340/).

Wilson, F.H., Mohadjer, Solmaz, Labay, K.A., and Shew, Nora, 2006, Digital datasets for geologic map by Wilson, F.H., Blodgett, R.B., Blome, C.D., Mohadjer, Solmaz, Preller, C.C., Klimasauskas, E.P., Gamble, B.M., and Coonrad, W.L., Preliminary integrated geologic map databases for the United States; digital data for the reconnaissance bedrock geologic map for the Northern Alaska Peninsula area, Southwest Alaska; including the Dillingham, Iliamna, Lake Clark, Taylor Mountains, and the western part of the Kenai and Seldovia 1:250,000-scale quadrangles: U.S. Geological Survey Open File Report 2006-1303 (online only at http://pubs.usgs.gov/of/2006/1303/).

Winkler, G.R., 1976, Deep-sea fan deposition of the Lower Tertiary Orca Group, eastern Prince William Sound, Alaska, in Miller, T.P., ed., Recent and ancient sedimentary environments in Alaska: Anchorage, Alaska, Alaska Geological Society Symposium volume, p. R1-R20.

Winkler, G.R., and Plafker, George, 1981, Geologic map and cross sections of the Cordova and Middleton Island quadrangles, southern Alaska: U.S. Geological Survey OpenFile Report 81-1164, scale 1:250,000.

Winkler, G.R., and Plafker, George, 1993, Geologic map of the Cordova and Middleton Island quadrangles, southern Alaska: U.S. Geological Survey Miscellaneous Investigations Map I-1984, scale 1:250,000.

Winkler, G.R., Silberman, M.L., Grantz, Arthur, Miller, R.J., and MacKevett, E.M., Jr., 1981, Geologic map and summary geochronology of the Valdez quadrangle, southern Alaska: U.S. Geological Survey Open-File Report 80-892-A, 2 sheets, scale 1:250,000.

Winkler, G.R., and Tysdal, R.G., 1977, Conglomerate in flysch 
of the Orca Group, Prince William Sound, southern Alaska, in Blean, K.M., ed., The United States Geological Survey in Alaska; Accomplishments during 1976: U.S. Geological Survey Circular 751-B, p. 43-44.

Wolfe, J.A., 1977, Paleogene floras from the Gulf of Alaska region: U.S. Geological Survey Professional Paper 997, $108 \mathrm{p}$.

Wolfe, J.A., and Tanai, T., 1980, The Miocene Seldovia Point flora from the Kenai Group, Alaska: U.S. Geological Survey Professional Paper 1105, $52 \mathrm{p}$.

Wood, F.J., editor-in-chief, 1967, The Prince William Sound, Alaska, earthquake of 1964 and aftershocks, Volume II Research Studies: Seismology and marine geology, Part A Engineering seismology: U.S. Department of Commerce, Environmental Science Services Administration, Coast and Geodetic Survey, Publication 10-3, v. 2, part A, 392 p. 
Table 1. Radiometric ages from the Prince William Sound and Cook Inlet region.

[Table sorted by map unit, from youngest to oldest. 1:250,000-scale quadrangles: BS, Blying Sound; CV, Cordova; KN, Kenai; MI, Middleton Island; SR, Seward; SV, Seldovia; n.a. indicates data not available]

\begin{tabular}{|c|c|c|c|c|c|c|c|c|c|c|c|}
\hline $\begin{array}{l}\text { Unit } \\
\text { sampled }\end{array}$ & $\begin{array}{l}\text { Sample } \\
\text { number }\end{array}$ & Quad. & $\begin{array}{l}\text { Latitude } \\
{ }^{\circ} \mathrm{N}\end{array}$ & $\begin{array}{l}\text { Longitude } \\
{ }^{\circ} \mathbf{W}\end{array}$ & Rock type & Method & Mineral & $\begin{array}{l}\text { Age } \\
\text { (Ma) }\end{array}$ & $\begin{array}{l}\text { Error } \\
\text { (m.y.) }\end{array}$ & Notes & References \\
\hline Qad & 78AR 290DK & $\mathrm{KN}$ & 60.7167 & 152.6667 & Andesite & $\mathrm{K}-\mathrm{Ar}$ & Whole-rock & 0.763 & 0.017 & $\begin{array}{l}\text { Dark band in banded andesite; mini- } \\
\text { mum age }\end{array}$ & Reed and others, 1992 \\
\hline Qad & 78AR 290LT & $\mathrm{KN}$ & 60.7167 & 152.6667 & Andesite & $\mathrm{K}-\mathrm{Ar}$ & Whole-rock & 0.627 & 0.024 & $\begin{array}{l}\text { Light band in banded andesite; } \\
\text { minimum age }\end{array}$ & Reed and others, 1992 \\
\hline Qad & 90AR 99 & $\mathrm{KN}$ & 60.77 & 152.7 & Andesite & $\mathrm{K}-\mathrm{Ar}$ & Whole-rock & 0.887 & 0.015 & Estimated latitude and longitude & Reed and others, 1992 \\
\hline Ts & $7-14-73-3$ & $\mathrm{KN}$ & 60.0683 & 151.6467 & Ash & Fission-track & Zircon & 8.5 & 1.0 & $\begin{array}{l}\text { Kenai Peninsula. Age revised in } \\
\text { Turner and others, } 1980 .\end{array}$ & $\begin{array}{l}\text { Triplehorn and others, 1977; Turner } \\
\text { and others, } 1980\end{array}$ \\
\hline Ts & $7-14-73-3$ & $\mathrm{KN}$ & 60.0683 & 151.6467 & Ash & $\mathrm{K}-\mathrm{Ar}$ & Plagioclase & 8.9 & 1.0 & $\begin{array}{l}\text { Kenai Peninsula. Age revised in } \\
\text { Turner and others, } 1980 .\end{array}$ & $\begin{array}{l}\text { Triplehorn and others, 1977; Turner } \\
\text { and others, } 1980\end{array}$ \\
\hline Ts & $7-13-73-9$ & $\mathrm{KN}$ & 60.1858 & 151.4617 & Ash & $\mathrm{K}-\mathrm{Ar}$ & Plagioclase & 7.0 & 0.7 & $\begin{array}{l}\text { Kenai Peninsula, location revised. } \\
\text { Age revised in Turner and others, } \\
1980 .\end{array}$ & $\begin{array}{l}\text { Triplehorn and others, 1977; Turner } \\
\text { and others, } 1980\end{array}$ \\
\hline Ts & $7-13-73-6$ & $\mathrm{KN}$ & 60.205 & 151.4333 & Ash & $\mathrm{K}-\mathrm{Ar}$ & $\begin{array}{l}\text { Hornblende } \\
\text { Plagioclase }\end{array}$ & $\begin{array}{l}7.4 \\
8.8\end{array}$ & $\begin{array}{l}0.7 \\
0.5\end{array}$ & Do. & Do. \\
\hline Ts & DT75-200 & $\mathrm{KN}$ & 60.2358 & 151.4008 & Ash & Fission-track & Zircon & 6.60 & 0.7 & $\begin{array}{l}\text { Sterling Formation, Clamgulchian } \\
\text { Stage }\end{array}$ & Turner and others, 1980 \\
\hline Ts & DT75-201 & $\mathrm{KN}$ & 60.205 & 151.435 & Tuff & $\mathrm{K}-\mathrm{Ar}$ & $\begin{array}{l}\text { Hornblende } \\
\text { Plagioclase }\end{array}$ & $\begin{array}{l}5.0 \\
5.9\end{array}$ & $\begin{array}{l}0.8 \\
0.5\end{array}$ & $\begin{array}{l}\text { Crystal tuff. Mean of } 2 \text { splits for both } \\
\text { minerals. }\end{array}$ & Turner and others, 1980 \\
\hline Ts & DT75-208 & SV & 59.7967 & 151.1117 & Tuff & $\mathrm{K}-\mathrm{Ar}$ & $\begin{array}{l}\text { Hornblende } \\
\text { Plagioclase }\end{array}$ & $\begin{array}{l}4.7 \\
4.2\end{array}$ & $\begin{array}{l}0.6 \\
1.4\end{array}$ & $\begin{array}{l}35 \mathrm{~m} \text { stratigraphically higher than } \\
\text { DT75-206. }\end{array}$ & Turner and others, 1980 \\
\hline Ts & DT75-207 & SV & 59.7967 & 151.1117 & Tuff & Fission-track & Zircon & 4.9 & 0.8 & $\begin{array}{l}\text { 24m stratigraphically higher than } \\
\text { DT75-206. }\end{array}$ & Turner and others, 1980 \\
\hline Ts & DT75-207 & SV & 59.7967 & 151.1117 & Tuff & $\mathrm{K}-\mathrm{Ar}$ & Plagioclase & $\begin{array}{l}7.5 \\
7.6\end{array}$ & $\begin{array}{l}0.6 \\
0.6\end{array}$ & $\begin{array}{l}24 \mathrm{~m} \text { stratigraphically higher than } \\
\text { DT75-206. Believed to be too old due } \\
\text { to detrital contamination. }\end{array}$ & Turner and others, 1980 \\
\hline Ts & DT75-206 & SV & 59.7967 & 151.1117 & Ash & Fission-track & Zircon & 5.6 & 0.9 & Composite of four thin beds. & Turner and others, 1980 \\
\hline Ts & DT75-206 & SV & 59.7967 & 151.1117 & Ash & $\mathrm{K}-\mathrm{Ar}$ & Plagioclase & $\begin{array}{l}4.6 \\
8.4\end{array}$ & $\begin{array}{l}0.7 \\
0.7\end{array}$ & $\begin{array}{l}\text { Composite of four thin ash beds. } 8.4 \\
\text { Ma age may be too old due to detrital } \\
\text { contamination. }\end{array}$ & Turner and others, 1980 \\
\hline Ts? & DT75-209b & SV & 59.7967 & 151.1083 & Tuff & $\mathrm{K}-\mathrm{Ar}$ & Plagioclase & $\begin{array}{l}9.1 \\
8.2\end{array}$ & $\begin{array}{l}0.7 \\
0.8\end{array}$ & $\begin{array}{l}\text { Sterling? Formation. Age may be too } \\
\text { old due to detrital contamination. }\end{array}$ & Turner and others, 1980 \\
\hline Ts & DT75-212 & SV & 59.77 & 151.1333 & Ash & $\mathrm{K}-\mathrm{Ar}$ & Plagioclase & & & $\begin{array}{l}33 \mathrm{~m} \text { stratigraphically above DT75- } \\
\text { 211. Ages may be too old due to } \\
\text { detrital contamination. }\end{array}$ & Turner and others, 1980 \\
\hline Ts & DT75-211 & SV & 59.77 & 151.1333 & Ash & Fission-track & Zircon & 5.4 & 0.6 & $\begin{array}{l}\text { 20-40m stratigraphically above } \\
\text { DT75-210. }\end{array}$ & Turner and others, 1980 \\
\hline Ts & DT75-211 & SV & 59.77 & 151.1333 & Ash & $\mathrm{K}-\mathrm{Ar}$ & Plagioclase & $\begin{array}{l}11.7 \\
14.1\end{array}$ & $\begin{array}{l}0.7 \\
0.7\end{array}$ & $\begin{array}{l}20-40 \mathrm{~m} \text { stratigraphically above } \\
\text { DT } 75-210 \text {. Ages may be too old due } \\
\text { to detrital contamination. }\end{array}$ & Turner and others, 1980 \\
\hline Ts & DT75-210 & SV & 59.77 & 151.1333 & Ash & $\mathrm{K}-\mathrm{Ar}$ & Plagioclase & 7.2 & 0.6 & $\begin{array}{l}\text { Sterling Formation, Clamgulchian } \\
\text { Stage }\end{array}$ & Turner and others, 1980 \\
\hline
\end{tabular}


Table 1. Radiometric ages from the Prince William Sound and Cook Inlet region — continued

\begin{tabular}{|c|c|c|c|c|c|c|c|c|c|c|c|}
\hline $\begin{array}{l}\text { Unit } \\
\text { sampled }\end{array}$ & $\begin{array}{l}\text { Sample } \\
\text { number }\end{array}$ & Quad. & $\begin{array}{l}\text { Latitude } \\
{ }^{\circ} \mathrm{N}\end{array}$ & $\begin{array}{l}\text { Longitude } \\
{ }^{\circ} \mathbf{W}\end{array}$ & Rock type & Method & Mineral & $\begin{array}{l}\text { Age } \\
\text { (Ma) }\end{array}$ & $\begin{array}{l}\text { Error } \\
\text { (m.y.) }\end{array}$ & Notes & References \\
\hline Ts & $6-25-77-1$ & SV & 59.8233 & 151.0417 & Ash & $\mathrm{K}-\mathrm{Ar}$ & Plagioclase & 6.9 & 0.5 & $\begin{array}{l}\text { Sterling Formation, Clamgulchian } \\
\text { Stage }\end{array}$ & Turner and others, 1980 \\
\hline $\mathrm{Tb}$ & $7-21-73-1$ & SV & 59.7683 & 151.1575 & Ash & Fission-track & Zircon & 8.8 & 1.0 & $\begin{array}{l}\text { Age revised in Turner and others, } \\
1980 .\end{array}$ & $\begin{array}{l}\text { Triplehorn and others, 1977; Turner } \\
\text { and others, } 1980\end{array}$ \\
\hline $\mathrm{Tb} ?$ & $7-21-73-1$ & SV & 59.7683 & 151.1575 & Ash & $\mathrm{K}-\mathrm{Ar}$ & Plagioclase & 11.3 & 0.7 & $\begin{array}{l}\text { Beluga? Formation. Age revised in } \\
\text { Turner and others, } 1980 .\end{array}$ & $\begin{array}{l}\text { Triplehorn and others, 1977; Turner } \\
\text { and others, } 1980\end{array}$ \\
\hline $\mathrm{Tb}$ & DT75-203 & SV & 59.7033 & 151.2783 & Tuff & Fission-track & Apatite & 12.9 & 5.1 & $\begin{array}{l}\text { Crystal vitric tuff mostly altered to } \\
\text { clay. }\end{array}$ & Turner and others, 1980 \\
\hline $\mathrm{Tb}$ & DT75-203 & SV & 59.7033 & 151.2783 & Tuff & $\mathrm{K}-\mathrm{Ar}$ & Plagioclase & 8.8 & 0.9 & $\begin{array}{l}\text { Crystal vitric tuff mostly altered to } \\
\text { clay. Mean of } 2 \text { analyses }\end{array}$ & Turner and others, 1980 \\
\hline $\mathrm{Tb}$ & DT75-202 & SV & 59.71 & 151.2383 & Tuff & $\mathrm{K}-\mathrm{Ar}$ & Plagioclase & 7.2 & 1.3 & Crystal vitric tuff. & Turner and others, 1980 \\
\hline $\mathrm{Tb}$ & DT75-204 & SV & 59.7117 & 151.2683 & Ash & Fission-track & Zircon & 7.6 & 0.7 & & Turner and others, 1980 \\
\hline $\mathrm{Tb}$ & DT75-204 & SV & 59.7117 & 151.2683 & Ash & $\mathrm{K}-\mathrm{Ar}$ & Plagioclase & 8.1 & 0.7 & Mean of 2 analyses & Turner and others, 1980 \\
\hline $\mathrm{Tb} ?$ & $7-22-73-4$ & SV & 59.7617 & 151.1692 & Ash & Fission-track & Zircon & 8.1 & 1.0 & $\begin{array}{l}\text { Beluga? Formation. Age revised in } \\
\text { Turner and others, } 1980 .\end{array}$ & $\begin{array}{l}\text { Triplehorn and others, 1977; Turner } \\
\text { and others, } 1980\end{array}$ \\
\hline $\mathrm{Tb} ?$ & $7-22-73-4$ & SV & 59.7617 & 151.1692 & Ash & $\mathrm{K}-\mathrm{Ar}$ & Plagioclase & 8.1 & 0.8 & $\begin{array}{l}\text { Beluga? Formation. Age revised in } \\
\text { Turner and others, } 1980 .\end{array}$ & $\begin{array}{l}\text { Triplehorn and others, 1977; Turner } \\
\text { and others, } 1980\end{array}$ \\
\hline Tovs & 71APr 23A & $\mathrm{CV}$ & 60.8675 & 146.1692 & Amphibolite & $\mathrm{K}-\mathrm{Ar}$ & Hornblende & 47.60 & 1.4 & $\begin{array}{l}\text { Greenschist facies amphibolite, loca- } \\
\text { tion revised. }\end{array}$ & $\begin{array}{l}\text { Winkler and Plafker, 1981; Nelson } \\
\text { and others, } 1985\end{array}$ \\
\hline Tdc & 80AMH 159A & MI & 59.7969 & 144.5864 & Dacite & $\mathrm{K}-\mathrm{Ar}$ & Whole-rock & 6.2 & .3 & Dacite of Cape St. Elias. & Nelson and others, 1985 \\
\hline Tpv & 72APr 76A1 & MI & 59.9133 & 144.3817 & Basalt & $\mathrm{K}-\mathrm{Ar}$ & Whole-rock & 31.20 & 1.3 & $\begin{array}{l}\text { Basaltic dike from Kayak Island. } \\
\text { Analytical data does not match } \\
\text { reported age. }\end{array}$ & $\begin{array}{l}\text { Winkler and Plafker, 1981; Nelson } \\
\text { and others, } 1985\end{array}$ \\
\hline $\mathrm{Tm}$ & 72APr 22A1 & $\mathrm{CV}$ & 60.0000 & 144.1958 & Diorite & $\mathrm{K}-\mathrm{Ar}$ & Hornblende & 200.5 & 29 & $\begin{array}{l}\text { Recalculated using constants of } \\
\text { Steiger and Jager, 1977. Age highly } \\
\text { suspect, too old. }\end{array}$ & $\begin{array}{l}\text { George Plafker, written commun., } \\
1986\end{array}$ \\
\hline Tov & $72 \mathrm{APr} 2 \mathrm{~A} 3$ & $\mathrm{CV}$ & 60.5567 & 145.7517 & Basalt & $\mathrm{K}-\mathrm{Ar}$ & Whole-rock & 43.00 & 6.1 & $\begin{array}{l}\text { Recalculated using constants of } \\
\text { Steiger and Jager, } 1977 .\end{array}$ & $\begin{array}{l}\text { George Plafker, written commun., } \\
1986\end{array}$ \\
\hline Tov & 83APr 312 & $\mathrm{CV}$ & 60.9750 & 146.7183 & Diabase & $\mathrm{K}-\mathrm{Ar}$ & Whole-rock & 130.00 & 14.0 & $\begin{array}{l}\text { Johnstone Cove. Recalculated using } \\
\text { constants of Steiger and Jager, } 1977 . \\
\text { Age highly suspect due to excess } \\
\text { argon. }\end{array}$ & $\begin{array}{l}\text { George Plafker, written commun., } \\
1986\end{array}$ \\
\hline Tod & 92SN 5a & SR & 60.8722 & 147.179 & Mafic dike & 40/39 Plateau & Plagioclase & 37.6 & 0.6 & $\begin{array}{l}\text { Sheeted dike from ophiolite, approxi- } \\
\text { mate location. }\end{array}$ & Nelson and others, 1999 \\
\hline Tod & $81 \mathrm{BS} 011 \mathrm{~A}$ & BS & 59.953 & 149.268 & Basaltic rock & $\mathrm{K}-\mathrm{Ar}$ & Whole-rock & 49.6 & 2.5 & & Miller, 1984 \\
\hline Tod & 81BS 011B & BS & 59.953 & 149.268 & Basaltic rock & $\mathrm{K}-\mathrm{Ar}$ & Whole-rock & 45.7 & 2.3 & & Miller, 1984 \\
\hline Tod & 81BS 013K & BS & 59.883 & 149.278 & Basaltic rock & $\mathrm{K}-\mathrm{Ar}$ & Whole-rock & 47.3 & 2.4 & & Miller, 1984 \\
\hline Tod & 81BS 017B & SR & 60.350 & 147.6484 & Mafic rock & $\mathrm{K}-\mathrm{Ar}$ & Whole-rock & 35 & 1.3 & & Miller, 1984 \\
\hline
\end{tabular}


Table 1. Radiometric ages from the Prince William Sound and Cook Inlet region — continued

\begin{tabular}{|c|c|c|c|c|c|c|c|c|c|c|c|}
\hline $\begin{array}{l}\text { Unit } \\
\text { sampled }\end{array}$ & $\begin{array}{l}\text { Sample } \\
\text { number }\end{array}$ & Quad. & $\begin{array}{l}\text { Latitude } \\
{ }^{\circ} \mathrm{N}\end{array}$ & $\begin{array}{l}\text { Longitude } \\
{ }^{\circ} \mathbf{W}\end{array}$ & Rock type & Method & Mineral & $\begin{array}{l}\text { Age } \\
\text { (Ma) }\end{array}$ & $\begin{array}{l}\text { Error } \\
\text { (m.y.) }\end{array}$ & Notes & References \\
\hline Tod & 81BS 034E & SR & 60.373 & 147.708 & Mafic rock & $\mathrm{K}-\mathrm{Ar}$ & Whole-rock & 38.8 & 1.9 & & Miller, 1984 \\
\hline Togb & n.a. & BS & 59.9491 & 149.2228 & Plagio-granite & $\mathrm{U}-\mathrm{Pb}$ & Zircon & 57 & n.a. & Plagiogranite intruding gabbro. & Nelson and others, 1989 \\
\hline $\mathrm{Tg}$ & PW8 & SR & 60.4503 & 148.1063 & Quartz diorite & $\mathrm{K}-\mathrm{Ar}$ & $\begin{array}{l}\text { Biotite } \\
\text { Hornblende }\end{array}$ & $\begin{array}{l}37.1 \\
35.3\end{array}$ & $\begin{array}{l}1.0 \\
1.2\end{array}$ & $\begin{array}{l}\text { Eshamy Granite, age recalculated } \\
\text { using constants of Steiger and Jager, } \\
1977 .\end{array}$ & $\begin{array}{l}\text { Lanphere, 1966; Magoon and others, } \\
\text { 1976; Tysdal and Case, 1979; Nelson } \\
\text { and others, } 1985\end{array}$ \\
\hline $\operatorname{Tg}$ & PW9 & SR & 60.4917 & 148.3833 & $\begin{array}{l}\text { Quartz } \\
\text { monzonite }\end{array}$ & K-Ar & Biotite & 37.1 & 0.9 & $\begin{array}{l}\text { Nellie Juan Granite, age recalculated } \\
\text { using constants of Steiger and Jager, } \\
1977 .\end{array}$ & $\begin{array}{l}\text { Lanphere, 1966; Magoon and others, } \\
\text { 1976; Tysdal and Case, 1979; Nelson } \\
\text { and others, } 1985\end{array}$ \\
\hline $\operatorname{Tg}$ & PW2 & SR & 60.8227 & 148.0752 & Granodiorite & K-Ar & Biotite & 36.4 & .9 & $\begin{array}{l}\text { Esther Granite, age recalculated using } \\
\text { constants of Steiger and Jager, } 1977 .\end{array}$ & $\begin{array}{l}\text { Lanphere, 1966; Magoon and others, } \\
\text { 1976; Tysdal and Case, 1979; Nelson } \\
\text { and others, } 1985\end{array}$ \\
\hline $\operatorname{Tg}$ & 92SN 14 & SR & 60.9772 & 147.1485 & Granite & 40/39 Plateau & K-feldspar & 29.2 & 0.1 & $\begin{array}{l}\text { Granite Cove. K-feldspar is suspect } \\
\text { material for dating, probably too } \\
\text { young. }\end{array}$ & Nelson and others, 1999 \\
\hline $\operatorname{Tg}$ & 92SN 12 & SR & 60.9817 & 147.42 & Granite & 40/39 Isochron & K-feldspar & 31.7 & 0.1 & $\begin{array}{l}\text { Cedar Bay. K-feldspar is suspect } \\
\text { material for dating, probably too } \\
\text { young. }\end{array}$ & Nelson and others, 1999 \\
\hline $\operatorname{Tg}$ & 80ANS 60A & SR & 60.74 & 147.9578 & Granitic rock & $\mathrm{K}-\mathrm{Ar}$ & Whole-rock & 34.2 & 1.7 & $\begin{array}{l}\text { Granite/granodiorite on Perry Island. } \\
\text { Inherently suspect because it is a } \\
\text { whole-rock age on a granitic rock. }\end{array}$ & Nelson and others, 1985 \\
\hline Tgd & PW1 & SR & 60.8325 & 148.4675 & Granodiorite & $\mathrm{K}-\mathrm{Ar}$ & Biotite & 37.6 & 1.0 & $\begin{array}{l}\text { Granite of Passage Canal, age recal- } \\
\text { culated using constants of Steiger and } \\
\text { Jager, } 1977 \text {. }\end{array}$ & $\begin{array}{l}\text { Lanphere, 1966; Magoon and others, } \\
\text { 1976; Tysdal and Case, 1979; Nelson } \\
\text { and others, } 1985\end{array}$ \\
\hline Tgg & $85 \operatorname{APr} 140$ & $\mathrm{CV}$ & 60.5383 & 145.1867 & Dacite & $\mathrm{K}-\mathrm{Ar}$ & Whole-rock & 47.23 & n.a. & Dacite porphyry. & $\begin{array}{l}\text { George Plafker, written commun., } \\
1986\end{array}$ \\
\hline Tgg & 84APr 9 & $\mathrm{CV}$ & 60.5733 & 145.2517 & Granodiorite & $\mathrm{K}-\mathrm{Ar}$ & Biotite & 51.4 & 1.5 & North of McKinley Peak. & $\begin{array}{l}\text { George Plafker, written commun., } \\
1986\end{array}$ \\
\hline Tgg & $84 \mathrm{APr} 8$ & $\mathrm{CV}$ & 60.7017 & 145.4867 & Granodiorite & $\mathrm{K}-\mathrm{Ar}$ & $\begin{array}{l}\text { Biotite } \\
\text { Hornblende }\end{array}$ & $\begin{array}{l}52.3 \\
49.9\end{array}$ & $\begin{array}{l}1.6 \\
1.5\end{array}$ & $\begin{array}{l}\text { Near head of Orca Inlet. Hornblende } \\
\text { age is considered a minimum age. }\end{array}$ & $\begin{array}{l}\text { George Plafker, written commun., } \\
1986\end{array}$ \\
\hline Tgg & 80ANS 148A & $\mathrm{CV}$ & 60.589 & 144.4096 & Granitic rock & $\mathrm{K}-\mathrm{Ar}$ & $\begin{array}{l}\text { Biotite } \\
\text { Hornblende }\end{array}$ & $\begin{array}{l}52.7 \\
51.3\end{array}$ & $\begin{array}{l}1.6 \\
2.9\end{array}$ & South side of Miles Glacier. & Nelson and others, 1985 \\
\hline Tgg & 67APr 1 & $\mathrm{CV}$ & 60.465 & 145.299 & Granitic rock & $\mathrm{K}-\mathrm{Ar}$ & Phlogopite & 51.6 & 2 & $\begin{array}{l}\text { Northwest of McKinley Peak; loca- } \\
\text { tion revised. }\end{array}$ & $\begin{array}{l}\text { Winkler and Plafker, 1981; Plafker } \\
\text { and others, 1985; Nelson and others, } \\
1985\end{array}$ \\
\hline Tgg & n.a. & $\mathrm{CV}$ & 60.4883 & 144.395 & Granodiorite & $\mathrm{K}-\mathrm{Ar}$ & Biotite & 52.2 & n.a. & & $\begin{array}{l}\text { Tysdal and others, 1976; Plafker and } \\
\text { Lanphere, 1974; Plafker, } 1974\end{array}$ \\
\hline Tgg & 71APr 20B & $\mathrm{CV}$ & 60.61 & 144.19 & Granitoid & $\mathrm{K}-\mathrm{Ar}$ & Hornblende & 50.6 & 1.5 & & $\begin{array}{l}\text { Winkler and Plafker, 1981; Nelson } \\
\text { and others, } 1985\end{array}$ \\
\hline
\end{tabular}


Table 1. Radiometric ages from the Prince William Sound and Cook Inlet region — continued

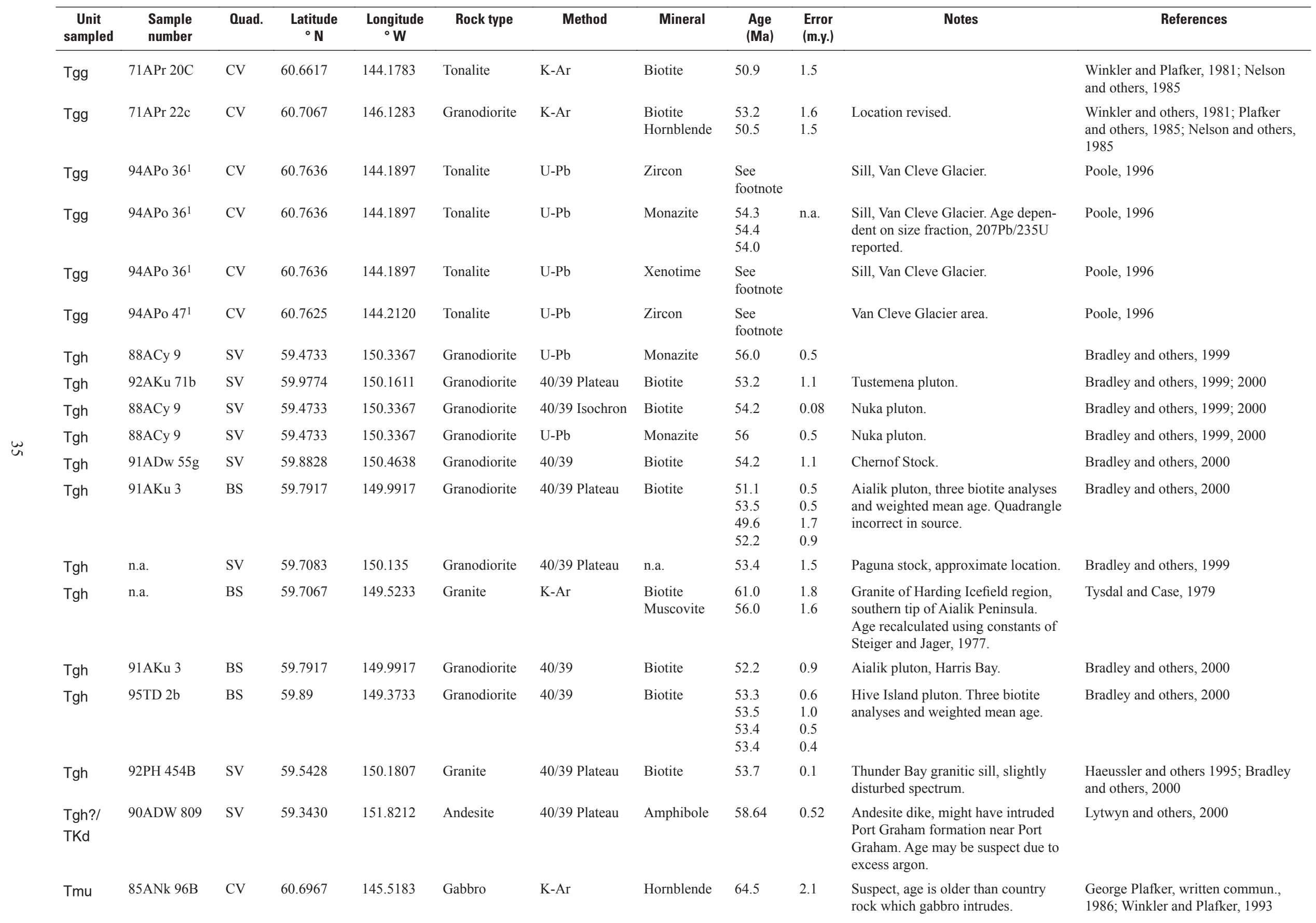


Table 1. Radiometric ages from the Prince William Sound and Cook Inlet region — continued

\begin{tabular}{|c|c|c|c|c|c|c|c|c|c|c|c|}
\hline $\begin{array}{l}\text { Unit } \\
\text { sampled }\end{array}$ & $\begin{array}{l}\text { Sample } \\
\text { number }\end{array}$ & Quad. & $\begin{array}{l}\text { Latitude } \\
{ }^{\circ} \mathbf{N}\end{array}$ & $\begin{array}{l}\text { Longitude } \\
{ }^{\circ} \mathbf{W}\end{array}$ & Rock type & Method & Mineral & $\begin{array}{l}\text { Age } \\
\text { (Ma) }\end{array}$ & $\begin{array}{l}\text { Error } \\
\text { (m.y.) }\end{array}$ & Notes & References \\
\hline Tmu & 85APr 177 & $\mathrm{CV}$ & 60.6762 & 145.4978 & $\begin{array}{l}\text { Altered } \\
\text { gabbro }\end{array}$ & $\mathrm{K}-\mathrm{Ar}$ & Hornblende & 48.5 & 1.5 & $\begin{array}{l}\text { Altered clinopyroxene gabbro in } \\
\text { written report, reported as hornblende } \\
\text { gabbro on map. }\end{array}$ & $\begin{array}{l}\text { George Plafker, written commun., } \\
\text { 1986; Winkler and Plafker, } 1993\end{array}$ \\
\hline TKgd & 70AR 146 & $\mathrm{KN}$ & 60.7433 & 152.9583 & Granodiorite & $\mathrm{K}-\mathrm{Ar}$ & Biotite & 68.2 & 1.9 & $\begin{array}{l}\text { Age recalculated using constants of } \\
\text { Steiger and Jager, } 1977 .\end{array}$ & $\begin{array}{l}\text { Reed and Lanphere, 1972, 1973; } \\
\text { Magoon and others, } 1976\end{array}$ \\
\hline TKgd & 70AR 147 & $\mathrm{KN}$ & 60.865 & 152.68 & Granodiorite & $\mathrm{K}-\mathrm{Ar}$ & $\begin{array}{l}\text { Biotite } \\
\text { Hornblende }\end{array}$ & $\begin{array}{l}65.4 \\
67.6\end{array}$ & $\begin{array}{l}1.8 \\
2.0\end{array}$ & $\begin{array}{l}\text { Age recalculated using constants of } \\
\text { Steiger and Jager, } 1977 .\end{array}$ & $\begin{array}{l}\text { Reed and Lanphere, 1972, 1973; } \\
\text { Magoon and others, } 1976\end{array}$ \\
\hline TKgd & 70AR 140 & $\mathrm{KN}$ & 60.9433 & 152.8617 & Granodiorite & $\mathrm{K}-\mathrm{Ar}$ & $\begin{array}{l}\text { Biotite } \\
\text { Hornblende }\end{array}$ & $\begin{array}{l}65.1 \\
70.5\end{array}$ & $\begin{array}{l}1.9 \\
2.0\end{array}$ & $\begin{array}{l}\text { Age recalculated using constants of } \\
\text { Steiger and Jager. } 1977 .\end{array}$ & $\begin{array}{l}\text { Reed and Lanphere, 1972, 1973; } \\
\text { Magoon and others, 1976; Detterman } \\
\text { and others, } 1976\end{array}$ \\
\hline TKd & $92 \mathrm{SN} 4$ & SR & 60.9867 & 147.5138 & Porphyry & 40/39 Isochron & K-feldspar & 31.1 & 0.2 & $\begin{array}{l}\text { Unakwik Inlet, approximate location. } \\
\text { K-feldspar is suspect material for } \\
\text { dating, probably too young. }\end{array}$ & Nelson and others, 1999 \\
\hline TKd & $81 \mathrm{BS} 116 \mathrm{C}$ & SR & 60.6155 & 149.5680 & $\begin{array}{l}\text { Felsic igneous } \\
\text { rock }\end{array}$ & $\mathrm{K}-\mathrm{Ar}$ & Whole-rock & 52.5 & 1.6 & $\begin{array}{l}\text { Dike, near Gilpatrick Mountain, cut- } \\
\text { ting Valdez Group (Kvs). }\end{array}$ & $\begin{array}{l}\text { Nelson and others, 1985; Bradley and } \\
\text { others, } 1993\end{array}$ \\
\hline TKd & $88 \mathrm{ADw} 230$ & SV & 59.3933 & 150.665 & $\begin{array}{l}\text { Intermediate } \\
\text { igneous rock }\end{array}$ & 40/39 Isochron & Hornblende & 57 & 0.22 & $\begin{array}{l}\text { Leucocratic porphyry dike containing } \\
\text { feldspar and hornblende phenocrysts; } \\
\text { cuts the McHugh Complex near head } \\
\text { of Seldovia Bay. }\end{array}$ & Bradley and others, 1993, 1999, 2000 \\
\hline TKd & 93ASB 66 & SV & 59.3938 & 151.2186 & $\begin{array}{l}\text { Basaltic } \\
\text { andesite }\end{array}$ & 40/39 Plateau & Hornblende & 115 & 1.7 & $\begin{array}{l}\text { Hornblende-phyric basaltic andesite } \\
\text { dike cutting graywacke of McHugh } \\
\text { Complex } 4 \mathrm{~km} \mathrm{SE} \text { of the head of } \\
\text { Tutka Bay. }\end{array}$ & Bradley and others, 1999, 2000 \\
\hline Kqd & $70 \mathrm{AR} 158$ & $\mathrm{KN}$ & 60.8317 & 152.5817 & Quartz diorite & $\mathrm{K}-\mathrm{Ar}$ & $\begin{array}{l}\text { Biotite } \\
\text { Hornblende }\end{array}$ & $\begin{array}{l}70.0 \\
74.4\end{array}$ & $\begin{array}{l}2.0 \\
2.2\end{array}$ & $\begin{array}{l}\text { Age recalculated using constants of } \\
\text { Steiger and Jager, } 1977 .\end{array}$ & $\begin{array}{l}\text { Reed and Lanphere, 1972, 1973; } \\
\text { Magoon and others, 1976; Detterman } \\
\text { and others, } 1976\end{array}$ \\
\hline Kqd & 70AR 179 & $\mathrm{KN}$ & 60.985 & 152.28 & Quartz diorite & $\mathrm{K}-\mathrm{Ar}$ & $\begin{array}{l}\text { Biotite } \\
\text { Hornblende }\end{array}$ & $\begin{array}{l}71.3 \\
70.6\end{array}$ & $\begin{array}{l}2.0 \\
2.1\end{array}$ & $\begin{array}{l}\text { Age recalculated using constants of } \\
\text { Steiger and Jager, } 1977 .\end{array}$ & $\begin{array}{l}\text { Reed and Lanphere, 1972, 1973; } \\
\text { Magoon and others, 1976; Detterman } \\
\text { and others, } 1976\end{array}$ \\
\hline Kqd & 70AR 173 & $\mathrm{KN}$ & 60.7483 & 152.8117 & Diorite & $\mathrm{K}-\mathrm{Ar}$ & $\begin{array}{l}\text { Biotite } \\
\text { Hornblende }\end{array}$ & $\begin{array}{l}67.2 \\
71.5\end{array}$ & $\begin{array}{l}1.9 \\
2.1\end{array}$ & $\begin{array}{l}\text { Age recalculated using constants of } \\
\text { Steiger and Jager, } 1977 .\end{array}$ & $\begin{array}{l}\text { Reed and Lanphere, 1972, 1973; } \\
\text { Magoon and others, } 1976\end{array}$ \\
\hline Kvv & $81 \mathrm{BS} 001 \mathrm{~A}$ & BS & 59.929 & 149.324 & Metatuff & $\mathrm{K}-\mathrm{Ar}$ & Whole-rock & 54.4 & 2.7 & Fox Island. & Miller, 1984 \\
\hline Kvgs & $81 \mathrm{KMS} 25$ & SR & 60.3974 & 149.2185 & $\begin{array}{l}\text { Biotite semi- } \\
\text { schist }\end{array}$ & $\mathrm{K}-\mathrm{Ar}$ & Unknown & 51.5 & 1.5 & $\begin{array}{l}\text { Metamorphic age of Valdez Group } \\
\text { schist unit (Kvgs) along Placer River } \\
\text { Fault. }\end{array}$ & Nelson and others, 1985 \\
\hline Jnc & $62 \mathrm{ALe} 6 \mathrm{e}$ & $\mathrm{KN}$ & 60.1133 & 152.585 & Quartz diorite & $\mathrm{K}-\mathrm{Ar}$ & $\begin{array}{l}\text { Biotite } \\
\text { Hornblende }\end{array}$ & $\begin{array}{l}156.6 \\
159.7\end{array}$ & $\begin{array}{l}\text { n.a. } \\
\text { n.a. }\end{array}$ & $\begin{array}{l}\text { Rounded granitic boulders within the } \\
\text { Chisik Conglomerate Member of the } \\
\text { Naknek Formation. Recalculated age } \\
\text { using constants of Steiger and Jager, } \\
1977 .\end{array}$ & $\begin{array}{l}\text { Detterman and others, 1965; Magoon } \\
\text { and others, } 1976\end{array}$ \\
\hline $\mathrm{Jg}$ & 62 ALe 5 & $\mathrm{KN}$ & 60.2533 & 152.886 & Granodiorite & $\mathrm{K}-\mathrm{Ar}$ & $\begin{array}{l}\text { Biotite } \\
\text { Hornblende }\end{array}$ & $\begin{array}{l}174.0 \\
171.9\end{array}$ & $\begin{array}{l}\text { n.a. } \\
\text { n.a. }\end{array}$ & $\begin{array}{l}\text { Alaska-Aleutian Range batholith, } \\
\text { recalculated using constants of Stei- } \\
\text { ger and Jager, } 1977\end{array}$ & $\begin{array}{l}\text { Detterman and others, 1965, Reed } \\
\text { and Lanphere, 1969, 1972; Magoon } \\
\text { and others, } 1976\end{array}$ \\
\hline
\end{tabular}


Table 1. Radiometric ages from the Prince William Sound and Cook Inlet region — continued

\begin{tabular}{|c|c|c|c|c|c|c|c|c|c|c|c|}
\hline $\begin{array}{l}\text { Unit } \\
\text { sampled }\end{array}$ & $\begin{array}{l}\text { Sample } \\
\text { number }\end{array}$ & Quad. & $\begin{array}{l}\text { Latitude } \\
{ }^{\circ} \mathbf{N}\end{array}$ & $\begin{array}{l}\text { Longitude } \\
{ }^{\circ} \mathbf{W}\end{array}$ & Rock type & Method & Mineral & $\begin{array}{l}\text { Age } \\
\text { (Ma) }\end{array}$ & $\begin{array}{l}\text { Error } \\
\text { (m.y.) }\end{array}$ & Notes & References \\
\hline $\mathrm{Jg}$ & 70AR 175 & $\mathrm{KN}$ & 60.59 & 152.78 & Granodiorite & $\mathrm{K}-\mathrm{Ar}$ & Biotite & 97.8 & 2.8 & $\begin{array}{l}\text { Age recalculated using constants of } \\
\text { Steiger and Jager, } 1977 \text {. Age suspect, } \\
\text { may be reset by younger plutonism. }\end{array}$ & $\begin{array}{l}\text { Reed and Lanphere, 1972, 1973; } \\
\text { Magoon and others, 1976; Detterman } \\
\text { and others, } 1976\end{array}$ \\
\hline $\mathrm{Jg}$ & 70AR 177 & $\mathrm{KN}$ & 60.615 & 152.6283 & Quartz diorite & $\mathrm{K}-\mathrm{Ar}$ & $\begin{array}{l}\text { Biotite } \\
\text { Hornblende }\end{array}$ & $\begin{array}{l}163.0 \\
161.0\end{array}$ & $\begin{array}{l}4.7 \\
4.7\end{array}$ & $\begin{array}{l}\text { Age recalculated using constants of } \\
\text { Steiger and Jager, } 1977 .\end{array}$ & $\begin{array}{l}\text { Reed and Lanphere, 1972, 1973; } \\
\text { Magoon and others, 1976; Detterman } \\
\text { and others, } 1976\end{array}$ \\
\hline $\mathrm{Jg}$ & 70AR 178 & $\mathrm{KN}$ & 60.6767 & 152.4517 & Granodiorite & $\mathrm{K}-\mathrm{Ar}$ & $\begin{array}{l}\text { Biotite } \\
\text { Hornblende }\end{array}$ & $\begin{array}{l}165.0 \\
162.0\end{array}$ & $\begin{array}{l}4.8 \\
4.8\end{array}$ & $\begin{array}{l}\text { Age recalculated using constants of } \\
\text { Steiger and Jager, } 1977 .\end{array}$ & $\begin{array}{l}\text { Reed and Lanphere, 1972, 1973; } \\
\text { Magoon and others, 1976; Detterman } \\
\text { and others, } 1976\end{array}$ \\
\hline $\mathrm{Jg}$ & 66AR 1464 & $\mathrm{KN}$ & 60.8033 & 152.355 & $\begin{array}{l}\text { Quartz mon- } \\
\text { zonite }\end{array}$ & $\mathrm{K}-\mathrm{Ar}$ & Biotite & 159.0 & n.a. & $\begin{array}{l}\text { Age recalculated using constants of } \\
\text { Steiger and Jager, } 1977 .\end{array}$ & $\begin{array}{l}\text { Reed and Lanphere, 1969, 1972, } \\
\text { 1973; Magoon and others, 1976; Det- } \\
\text { terman and others, } 1976\end{array}$ \\
\hline $\mathrm{Jg}$ & 70AR 156 & $\mathrm{KN}$ & 60.805 & 152.4917 & Diorite & $\mathrm{K}-\mathrm{Ar}$ & Hornblende & 146.0 & 4.3 & $\begin{array}{l}\text { Age recalculated using constants of } \\
\text { Steiger and Jager, } 1977 .\end{array}$ & $\begin{array}{l}\text { Reed and Lanphere, 1972, 1973; } \\
\text { Magoon and others, 1976; Detterman } \\
\text { and others, } 1976\end{array}$ \\
\hline Jsch & 7AF23-9 & SV & 59.0033 & 151.7067 & Schist & $\mathrm{K}-\mathrm{Ar}$ & Muscovite & 194.7 & 5.7 & $\begin{array}{l}\text { Quartz-mica schist, approximate } \\
\text { location, age recalculated using con- } \\
\text { stants of Steiger and Jager, } 1977 .\end{array}$ & Carden and others, 1977 \\
\hline Jsch & 74PG79 & SV & 59.37 & 151.81 & Schist & $\mathrm{K}-\mathrm{Ar}$ & Muscovite & 196.1 & 5.8 & $\begin{array}{l}\text { Quartz-mica schist, approximate } \\
\text { location, age recalculated using con- } \\
\text { stants of Steiger and Jager, } 1977 .\end{array}$ & Carden and others, 1977 \\
\hline Jsch & SD3-3 & SV & 59.4617 & 151.7067 & Greenschist & $\mathrm{K}-\mathrm{Ar}$ & $\begin{array}{l}\text { Actinolite } \\
\text { Chlorite } \\
\text { White mica }\end{array}$ & $\begin{array}{l}195.0 \\
185.1 \\
192.3\end{array}$ & $\begin{array}{l}11.0 \\
8.3 \\
10.0\end{array}$ & $\begin{array}{l}\text { Approximate corrected location, con- } \\
\text { stants of Steiger and Jager, } 1977 .\end{array}$ & $\begin{array}{l}\text { Forbes and Lanphere, 1973; Magoon } \\
\text { and others, 1976; Carden and others, } \\
1977\end{array}$ \\
\hline Jsch & 74AF4B.1 & SV & 59.4617 & 151.7067 & Schist & $\mathrm{K}-\mathrm{Ar}$ & Crossite & 166.8 & 4.9 & $\begin{array}{l}\text { Blueschist, crossite date, approximate } \\
\text { location, recalculated using constants } \\
\text { of Steiger and Jager, } 1977 \text {. }\end{array}$ & Carden and others, 1977 \\
\hline Jsch & 74AF23-10 & SV & 59.4617 & 151.7067 & Schist & $\mathrm{K}-\mathrm{Ar}$ & $\begin{array}{l}\text { Amphibole } \\
\text { Muscovite }\end{array}$ & $\begin{array}{l}188.4 \\
196.6\end{array}$ & $\begin{array}{l}5.5 \\
5.8\end{array}$ & $\begin{array}{l}\text { Amphibole-mica schist, approximate } \\
\text { location, amphibole is average of } 2 \\
\text { splits, age recalculated using con- } \\
\text { stants of Steiger and Jager, } 1977 .\end{array}$ & Carden and others, 1977 \\
\hline Jsch & SD9-3 & SV & 59.4667 & 151.7333 & Schist & $\mathrm{K}-\mathrm{Ar}$ & $\begin{array}{l}\text { Crossite } \\
\text { Phengite }\end{array}$ & $\begin{array}{l}157.8 \\
192.9\end{array}$ & $\begin{array}{l}4.8 \\
5.7\end{array}$ & $\begin{array}{l}\text { Blueschist, crossite date may reflect } \\
\text { argon loss, approximate location, } \\
\text { recalculated using constants of Stei- } \\
\text { ger and Jager, } 1977 \text {. }\end{array}$ & $\begin{array}{l}\text { Forbes and Lanphere, 1973; Magoon } \\
\text { and others, 1976; Carden and others, } \\
1977\end{array}$ \\
\hline Jsch & 92ATi 316D & SV & 59.4479 & 151.7145 & Schist & 40/39 Plateau & White mica & 190.98 & 0.3 & Seldovia metamorphic complex. & $\begin{array}{l}\text { Bradley and Karl, 2000, A. Till (oral } \\
\text { commun., 2007) }\end{array}$ \\
\hline Jsch & 92ATi 309B & SV & 59.4547 & 151.7153 & Schist & 40/39 Plateau & Barroisite & 191.92 & 0.6 & $\begin{array}{l}\text { Seldovia metamorphic complex, } \\
\text { quartz-white mica-chlorite schist }\end{array}$ & $\begin{array}{l}\text { Bradley and Karl, 2000, A. Till (oral } \\
\text { commun., 2007) }\end{array}$ \\
\hline Jsch & 92ATi 309B & SV & 59.4547 & 151.7153 & Schist & 40/39 Plateau & Muscovite & 191.7 & 0.3 & $\begin{array}{l}\text { Seldovia metamorphic complex, } \\
\text { quartz-white mica-chlorite schist }\end{array}$ & $\begin{array}{l}\text { Bradley and Karl, 2000, A. Till (oral } \\
\text { commun., 2007) }\end{array}$ \\
\hline Mzg & 91DW 87 & SV & 59.6075 & 151.1378 & Gabbro & $\mathrm{U}-\mathrm{Pb}$ & Zircon & 227.7 & 0.6 & $\begin{array}{l}\text { Gabbro of Halibut Cove. Sample } \\
\text { number uncertain. }\end{array}$ & $\begin{array}{l}\text { Bradley and Karl, 2000; Bradley, oral } \\
\text { commun., } 2007\end{array}$ \\
\hline
\end{tabular}


Table 1. Radiometric ages from the Prince William Sound and Cook Inlet region — continued

\begin{tabular}{|c|c|c|c|c|c|c|c|c|c|c|c|}
\hline $\begin{array}{c}\text { Unit } \\
\text { sampled }\end{array}$ & $\begin{array}{l}\text { Sample } \\
\text { number }\end{array}$ & Quad. & $\begin{array}{l}\text { Latitude } \\
{ }^{\circ} \mathrm{N}\end{array}$ & $\begin{array}{l}\text { Longitude } \\
{ }^{\circ} \mathbf{W}\end{array}$ & Rock type & Method & Mineral & $\begin{array}{l}\text { Age } \\
\text { (Ma) }\end{array}$ & $\begin{array}{l}\text { Error } \\
\text { (m.y.) }\end{array}$ & Notes & References \\
\hline \multicolumn{12}{|c|}{ Dates recording hydrothermal alteration } \\
\hline-- & $92 \mathrm{PH} 216 \mathrm{f}$ & SR & 60.972 & 148.2112 & Granite & $40 / 39$ & White mica & $>53$ & -- & $\begin{array}{l}\text { Granite Mine, hydrothermally altered } \\
\text { granite. } 30 \% \text { of mica was light green } \\
\text { (chlorite?); analysis shows argon loss } \\
\text { spectra, no plateau. }\end{array}$ & Haeussler and others, 1995 \\
\hline-- & n.a. & SV & 59.3195 & 151.2917 & Felsic dike & $40 / 39$ & White mica & 57.3 & 0.1 & $\begin{array}{l}\text { Port Dick prospect, preferred hydro- } \\
\text { thermal alteration date from single } \\
\text { gas release step }\left(1000^{\circ} \mathrm{C}\right) \text { and } 67.8 \\
\text { percent of gas. }\end{array}$ & Haeussler and others, 1995 \\
\hline -- & n.a. & SV & 59.5392 & 150.4780 & n.a. & 40/39 Plateau & Sericite & 55.6 & 0.1 & $\begin{array}{l}\text { Beauty Bay Mine, altered rock, clear } \\
\text { sericite. }\end{array}$ & Haeussler and others, 1995 \\
\hline-- & n.a. & SV & 59.5392 & 150.4780 & n.a. & $40 / 39$ & Sericite & 55.9 & 0.1 & $\begin{array}{l}\text { Beauty Bay Mine, altered rocks, } \\
\text { gold-colored sericite. Preferred } \\
\text { date based on } 37.2 \text { percent of gas, } \\
\text { disturbed spectra. }\end{array}$ & Haeussler and others, 1995 \\
\hline-- & n.a. & SV & 59.5428 & 150.1800 & Vein & 40/39 Plateau & White mica & 52.9 & 0.1 & $\begin{array}{l}\text { Thunder Bay gold occurrence, poly- } \\
\text { metalllic gold-sulfide vein. }\end{array}$ & Haeussler and others, 1995 \\
\hline TKd & $2203 \mathrm{~N}$ & SR & 60.6667 & 149.75 & $\begin{array}{l}\text { Felsic igneous } \\
\text { rock }\end{array}$ & $\mathrm{K}-\mathrm{Ar}$ & Whole-rock & 52.7 & 1.6 & $\begin{array}{l}\text { Kenai Star Mine(?), hydrothermally } \\
\text { altered felsic dike, approximate } \\
\text { location. }\end{array}$ & $\begin{array}{l}\text { Silberman and others, 1981; Mitchell } \\
\text { and others, 1981; Haeussler and } \\
\text { others, } 1995\end{array}$ \\
\hline TKd & 2237B & SR & 60.8 & 149.667 & Granite & $\mathrm{K}-\mathrm{Ar}$ & Muscovite & 53.2 & 1.6 & $\begin{array}{l}\text { Hydrothermally altered albite-granite } \\
\text { dike, approximate location. }\end{array}$ & $\begin{array}{l}\text { Silberman and others, 1981; Mitchell } \\
\text { and others, 1981; Haeussler and } \\
\text { others, } 1995\end{array}$ \\
\hline $\operatorname{Tg} ?$ & $92 \mathrm{PH} 216 \mathrm{e}$ & SR & 60.972 & 148.2112 & Granite & $40 / 39$ & Biotite & 56. & 1. & $\begin{array}{l}\text { Granite Mine, hydrothermally altered } \\
\text { granite. Disturbed spectrum, chlorite } \\
\text { present, date is weighted average and } \\
\text { of low confidence. }\end{array}$ & Haeussler and others, 1995 \\
\hline
\end{tabular}

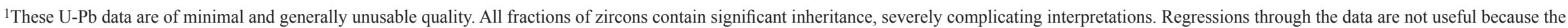

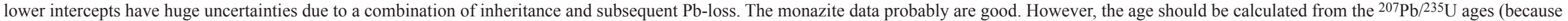

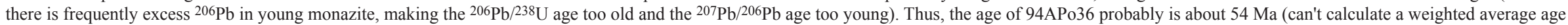

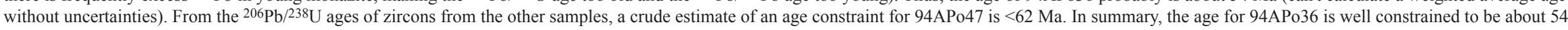
Ma. All other ages are relatively unknown. Thus, any tectonic scenario from these age data are untenable (J.N. Aleinikoff, USGS, written commun., 2007). 